\title{
Productivity, Respiration, and Light-Response Parameters of World Grassland and Agroecosystems Derived From Flux-Tower Measurements
}

\author{
Tagir G. Gilmanov, ${ }^{1}$ L. Aires, ${ }^{2}$ Z. Barcza, ${ }^{2}$ V. S. Baron, ${ }^{3}$ L. Belelli, ${ }^{2}$ J. Beringer, ${ }^{2}$ D. Billesbach, ${ }^{3}$
} D. Bonal, ${ }^{2}$ J. Bradford, ${ }^{2}$ E. Ceschia, ${ }^{2}$ D. Cook, ${ }^{2}$ C. Corradi, ${ }^{2}$ A. Frank, ${ }^{4}$ D. Gianelle, ${ }^{2}$ C. Gimeno, ${ }^{2,3}$ T. Gruenwald, ${ }^{2}$ Haiqiang Guo, ${ }^{2}$ N. Hanan, ${ }^{2}$ L. Haszpra, ${ }^{2}$ J. Heilman, ${ }^{2,3}$ A. Jacobs, ${ }^{2}$ M. B. Jones, ${ }^{3}$ D. A. Johnson, ${ }^{4}$ G. Kiely, ${ }^{2}$ Shenggong $\mathrm{Li}^{2}{ }^{2}$ V. Magliulo, ${ }^{2}$ E. Moors, ${ }^{2}$ Z. Nagy, ${ }^{2,3}$ M. Nasyrov, ${ }^{3}$ C. Owensby, ${ }^{3}$ K. Pinter, ${ }^{2,3}$ C. Pio, ${ }^{2}$ M. Reichstein, ${ }^{2}$ M. J. Sanz, ${ }^{2,3}$ R. Scott, ${ }^{2}$ J. F. Soussana, ${ }^{2,3}$ P. C. Stoy, ${ }^{2}$ T. Svejcar, ${ }^{4}$ Z. Tuba, ${ }^{2,3,5}$ and Guangsheng Zhou ${ }^{2}$

Authors are ${ }^{1}$ Professor, Department of Biology and Microbiology, South Dakota State University, Brookings, SAG 304, Box 2207B, SD 57007, USA; and researchers who contributed their data to the ${ }^{2}$ FLUXNET La Thuile data set, ${ }^{3}$ WORLDGRASSAGRIFLUX data set, or ${ }^{4}$ US Department of AgricultureAgricultural Research Service RANGEFLUX data set. ${ }^{5}$ Deceased.

\begin{abstract}
Grasslands and agroecosystems occupy one-third of the terrestrial area, but their contribution to the global carbon cycle remains uncertain. We used a set of 316 site-years of $\mathrm{CO}_{2}$ exchange measurements to quantify gross primary productivity, respiration, and light-response parameters of grasslands, shrublands/savanna, wetlands, and cropland ecosystems worldwide. We analyzed data from 72 global flux-tower sites partitioned into gross photosynthesis and ecosystem respiration with the use of the lightresponse method (Gilmanov, T. G., D. A. Johnson, and N. Z. Saliendra. 2003. Growing season $\mathrm{CO}_{2}$ fluxes in a sagebrushsteppe ecosystem in Idaho: Bowen ratio/energy balance measurements and modeling. Basic and Applied Ecology 4:167-183) from the RANGEFLUX and WORLDGRASSAGRIFLUX data sets supplemented by 46 sites from the FLUXNET La Thuile data set partitioned with the use of the temperature-response method (Reichstein, M., E. Falge, D. Baldocchi, D. Papale, R. Valentini, M. Aubinet, P. Berbigier, C. Bernhofer, N. Buchmann, M. Falk, T. Gilmanov, A. Granier, T. Grünwald, K. Havránková, D. Janous, A. Knohl, T. Laurela, A. Lohila, D. Loustau, G. Matteucci, T. Meyers, F. Miglietta, J. M. Ourcival, D. Perrin, J. Pumpanen, S. Rambal, E. Rotenberg, M. Sanz, J. Tenhunen, G. Seufert, F. Vaccari, T. Vesala, and D. Yakir. 2005. On the separation of net ecosystem exchange into assimilation and ecosystem respiration: review and improved algorithm. Global Change Biology 11:1424-1439). Maximum values of the quantum yield $\left(\alpha=75 \mathrm{mmol} \cdot \mathrm{mol}^{-1}\right)$, photosynthetic capacity $\left(A_{\max }=3.4 \mathrm{mg} \mathrm{CO} \cdot \mathrm{m}^{-2} \cdot \mathrm{s}^{-1}\right)$, gross photosynthesis $\left(P_{\mathrm{g}, \max }=116 \mathrm{~g} \mathrm{CO}_{2} \cdot \mathrm{m}^{-2} \cdot \mathrm{d}^{-1}\right)$, and ecological light-use efficiency $\left(\varepsilon_{\text {ecol }}=59 \mathrm{mmol} \cdot \mathrm{mol}^{-1}\right)$ of managed grasslands and high-production croplands exceeded those of most forest ecosystems, indicating the potential of nonforest ecosystems for uptake of atmospheric $\mathrm{CO}_{2}$. Maximum values of gross primary production $\left(8600 \mathrm{~g} \mathrm{CO}_{2} \cdot \mathrm{m}^{-2} \cdot \mathrm{yr}^{-1}\right)$, total ecosystem respiration $\left(7900 \mathrm{~g} \mathrm{CO}_{2} \cdot \mathrm{m}^{-2} \cdot \mathrm{yr}^{-1}\right)$, and net $\mathrm{CO}_{2}$ exchange $(2400 \mathrm{~g}$ $\mathrm{CO}_{2} \cdot \mathrm{m}^{-2} \cdot \mathrm{yr}^{-1}$ ) were observed for intensively managed grasslands and high-yield crops, and are comparable to or higher than those for forest ecosystems, excluding some tropical forests. On average, $80 \%$ of the nonforest sites were apparent sinks for atmospheric $\mathrm{CO}_{2}$, with mean net uptake of $700 \mathrm{~g} \mathrm{CO}_{2} \cdot \mathrm{m}^{-2} \cdot \mathrm{yr}^{-1}$ for intensive grasslands and $933 \mathrm{~g} \mathrm{CO}_{2} \cdot \mathrm{m}^{-2} \cdot \mathrm{d}^{-1}$ for croplands. However, part of these apparent sinks is accumulated in crops and forage, which are carbon pools that are harvested, transported, and decomposed off site. Therefore, although agricultural fields may be predominantly sinks for atmospheric $\mathrm{CO}_{2}$, this does not imply that they are necessarily increasing their carbon stock.
\end{abstract}

\section{Resumen}

Los pastizales y agro-ecosistemas ocupan un tercio de la superficie terrestre, pero su contribución en el ciclo del carbono global sigue siendo desconocida. Utilizamos un conjunto de 316 sitios-años de mediciones de intercambio de $\mathrm{CO}_{2}$ para cuantificar la productividad primaria bruta, respiración y parámetros de la a respuesta a la luz de pastizales, matorrales/sabana, humedales y los ecosistemas de tierras de cultivo en todo el mundo. Se analizaron datos de 72 torres en sitios de flujo global divididos en fotosíntesis bruta y respiración del ecosistema mediante el método de respuesta de luz (Gilmanov, T. G., D. A. Johnson, and N. Z. Saliendra. 2003. Growing season $\mathrm{CO}_{2}$ fluxes in a sagebrush-steppe ecosystem in Idaho: Bowen ratio/energy balance measurements and modeling. Basic and Applied Ecology 4:167-183) de los conjuntos de datos de RANGEFLUX y WORLDGRASSAGRIFLUX complementado por 46 sitios desde el conjunto de datos FLUXNET La Thuile divididos mediante el método de respuesta de temperatura (Reichstein, M., E. Falge, D. Baldocchi, D. Papale, R. Valentini, M. Aubinet, P.

Research was supported in part by the Science Applications International Corporation, Subcontract 4400089887 to Gilmanov Research and Consulting, LLP. Measurements at the Alinya site, Spain, Fundación CEAM were partly supported by Generalitat Valenciana, Bancaja, and the Programm CONSOLIDER-INGENIO 2010 (GRACCIE).

This publication was made possible through support provided to the Global Livestock Collaborative Research Support Program by the Office of Agriculture, Bureau for Economic Growth, Agriculture and Trade, United States Agency for International Development under terms of Grant No. PCE-G-00-98-00036-00. The opinions expressed herein are those of the author(s) and do not necessarily reflect the views of the USAID.

Correspondence: Tagir G. Gilmanov, Dept of Biology and Microbiology, South Dakota State University, SAG 305, Box 2207B, Brookings, SD 57006, USA. Email: tagir.gilmanov@sdstate.edu

Manuscript received 6 June 2009; manuscript accepted 13 July 2009. 
Berbigier, C. Bernhofer, N. Buchmann, M. Falk, T. Gilmanov, A. Granier, T. Grünwald, K. Havránková, D. Janous, A. Knohl, T. Laurela, A. Lohila, D. Loustau, G. Matteucci, T. Meyers, F. Miglietta, J. M. Ourcival, D. Perrin, J. Pumpanen, S. Rambal, E. Rotenberg, M. Sanz, J. Tenhunen, G. Seufert, F. Vaccari, T. Vesala, and D. Yakir. 2005. On the separation of net ecosystem exchange into assimilation and ecosystem respiration: review and improved algorithm. Global Change Biology 11:1424-1439). Los valores máximos del rendimiento cuántico $\left(\alpha=75 \mathrm{mmol} \cdot \mathrm{mol}^{-1}\right)$, capacidad de fotosíntesis $\left(A_{\max }=\&\right.$ hairsp3.4 mg $\mathrm{CO}_{2}$ $\left.\mathrm{m}^{-2} \mathrm{~s}^{-1}\right)$, fotosíntesis bruta $\left(P_{\mathrm{g}, \max }=116 \mathrm{~g} \mathrm{CO}_{2} \mathrm{~m}^{-2} \mathrm{~d}^{-1}\right)$, y la eficiencia ecológica de uso de la luz de praderas $\left(\varepsilon_{\mathrm{ecol}}=59 \mathrm{mmol} \cdot \mathrm{mol}^{-1}\right)$ manejadas y tierras de cultivo con alto nivel de producción ha superado los de la mayoría de los ecosistemas forestales, esto indica el potencial de los ecosistemas no forestales para la absorción de $\mathrm{CO}_{2}$ atmosférico. Los valores máximos de producción primaria bruta $\left(8600 \mathrm{~g} \mathrm{CO}_{2} \mathrm{~m}^{-2} \mathrm{yr}^{-1}\right)$, la respiración total del ecosistema $\left(7900 \mathrm{~g} \mathrm{CO}_{2} \mathrm{~m}^{-2} \mathrm{yr}^{-1}\right) \mathrm{y} \mathrm{el}$ intercambio de $\mathrm{CO}_{2}$ neto $\left(2400 \mathrm{~g} \mathrm{CO}_{2} \mathrm{~m}^{-2} \mathrm{yr}^{-1}\right.$ ) se observaron para pastizales manejados intensamente y cultivos de alto rendimiento y son comparables o superiores a los de los ecosistemas forestales, con exclusión de algunos bosques tropicales. En promedio, $80 \%$ de los sitios no forestales eran evidentes los sumideros de $\mathrm{CO}_{2}$ atmosférico, con un promedio neto de absorción de $700 \mathrm{~g} \mathrm{CO}_{2} \mathrm{~m}^{-2} \mathrm{yr}^{-1}$ para pastizales manejados intensivamente y $933 \mathrm{~g} \mathrm{CO}_{2} \mathrm{~m}^{-2} \mathrm{yr}^{-1}$ para tierras de cultivo. Sin embargo, parte de estos aparentes sumideros se acumulan en los cultivos y forrajes, que son reservorios de carbono que son cosechados, transportados y descompuestos fuera del sitio. Por lo tanto, aunque los campos agrícolas pueden ser predominantemente sumideros de $\mathrm{CO}_{2}$ atmosférico, esto no implica que necesariamente estén aumentando sus reservas de carbono.

Key Words: croplands, ecosystem respiration, grasslands, gross primary production, light-response function method, net $\mathrm{CO}_{2}$ flux partitioning, net ecosystem $\mathrm{CO}_{2}$ exchange

\section{INTRODUCTION}

Quantifying the contribution of different ecosystems to total regional, continental, and global stocks and exchanges of carbon has been recognized as a fundamental task since the initiation of the carbon cycle science (Rodin and Bazilevich 1968; Whittaker and Likens 1973; Lieth 1975; Olson et al. 1983). Generalizations concerning the role of forest, wetland, and tundra ecosystems in the global carbon budget have been provided recently and have resulted in a general consensus on the contribution of these ecosystem types to the carbon budget (Griffiths and Jarvis 2005; Davidson and Janssens 2006; Birdsey et al. 2007; Bridgham et al. 2007; Tarnocai et al. 2007). Considerably less agreement exists, however, with respect to grassland and cropland ecosystems.

Available estimates of carbon budgets at the country or continental levels typically characterize grasslands as weak sinks, or as approaching a carbon-neutral state, whereas croplands are considered moderate to strong sources of atmospheric carbon (Smith and Falloon 2005; Conant et al. 2007). It should be emphasized, however, that those assessments are not based on direct measurements of carbon exchange, but rather on indirect measures, such as biomass and soil organic matter inventories. Generally, indirect assessments involve combining agricultural fields, where organic matter is produced, with locations (feedlots, harvest processing plants, ethanol facilities, etc.) where harvested biomass is transported and utilized.

Although useful as an initial approximation, indirect measures need to be supplemented with additional data to understand the precise contributions of various land areas to regional atmospheric $\mathrm{CO}_{2}$ exchange. The objective of our study was to obtain reliable, measurement-based estimates of $\mathrm{CO}_{2}$ fluxes into and out of the system at the ecosystem scale from $\mathrm{CO}_{2}$ flux-tower records. Some authors consider maize (Zea mays L.) fields that produce grain harvests with little or no soil organic matter loss due to advanced agronomic practices, when considered together with ethanol-producing plants where this corn is processed, as only small net sinks for atmospheric $\mathrm{CO}_{2}$ (Powlson et al. 2005; Farrell et al. 2006) or even as net carbon sources (Patzek et al. 2005). However, the anthropogenic use of fixed carbon confounds the fact that the site is often a very strong sink for atmospheric $\mathrm{CO}_{2}$ (e.g., Buyanovsky and Wagner 1998; Bernacchi et al. 2006; Aubinet et al. 2009). Although managed agroecosystems may exhibit sink strength for atmospheric $\mathrm{CO}_{2}$, anthropogenic harvesting of the fixed carbon products (or erosion) may substantially alter the longterm carbon dynamics at particular sites (similar to timber harvesting in forests). Because decisions concerning the fate of the removed biomass are typically made by humans, opportunities may exist for substantial net sequestration of carbon in grasslands and croplands.

The number and duration of $\mathrm{CO}_{2}$ flux observations from nonforest flux-tower stations throughout the world have grown exponentially during the last decade. Through the La Thuile synthesis process of the FLUXNET network (Agarwal et al. 2008; Baldocchi 2008b) and other cooperative initiatives, these observations are now available for comparative analysis and generalization. In this publication, we present a synthesis of results from tower $\mathrm{CO}_{2}$ flux measurements at 118 tower sites representing grassland, cropland, shrubland, savanna, and wetland ecosystems of the world. We first describe the methodology used to derive the terms of the carbon balance used in the global ecosystem comparison, then compare characteristics of the global ecosystem carbon cycle, such as seasonal light responses and $\mathrm{CO}_{2}$ uptake of nonforest and forest ecosystems. Our objective was to obtain measurementbased estimates of the role of nonforest ecosystems as net sinks or sources for atmospheric $\mathrm{CO}_{2}$. Such estimates may provide a basis for establishing carbon credit markets and poverty alleviation projects.

\section{METHODS}

Data for this study were provided by the WORLDGRASSAGRIFLUX data set (Gilmanov and WORLDGRASSAGRIFLUX Data Set Participants 2007), which currently includes data from 72 nonforest sites (Table 1, method L) for which original 30-min (or 20-min in some sites) net $\mathrm{CO}_{2}$ flux $\left(F_{\mathrm{c}}\right)$ was 
Table 1. Nonforest flux-tower sites analyzed in this study.

\begin{tabular}{|c|c|c|c|c|c|c|c|c|}
\hline Site & Latitude & Longitude & Elevation & PCPN & $T_{\text {year }}$ & Years & Investigator(s) & Method $^{1}$ \\
\hline \multicolumn{9}{|l|}{ Croplands } \\
\hline Ames, IA, USA, maize & 41.720 & -93.410 & 300 & 814 & 8.9 & 2003 & J. Prueger & L \\
\hline Auradé, France & 43.549 & 1.108 & 243 & 690 & 13.3 & 2005 & E. Ceschia, P. Béziat & $\mathrm{T}$ \\
\hline Batavia-agro, IL, USA & 41.859 & -88.223 & 227 & 921 & 10.5 & 2005-2006 & R. Matamala; D. Cook & $\mathrm{T}$ \\
\hline Bondville, IL, USA, maize & 40.006 & -88.292 & 300 & 990 & 11.3 & $1997-2005$ & $\begin{array}{l}\text { S. Hollinger; C. Bernacchi, T. } \\
\text { Meyers }\end{array}$ & $L$ \\
\hline Bondville, IL, USA, soybeans & 40.006 & -88.292 & 300 & 990 & 11.3 & 1998-2006 & $\begin{array}{l}\text { S. Hollinger; C. Bernacchi, T. } \\
\text { Meyers }\end{array}$ & L \\
\hline Bondville-companion, IL, USA & 40.006 & -88.292 & 219 & 990 & 11.3 & 2005-2006 & S. Hollinger; C. Bernacchi & $\mathrm{T}$ \\
\hline Borgo Cioffi-crop, Italy & 40.524 & 14.957 & 20 & 490 & 19.0 & 2004-2006 & V. Magliulo & $\mathrm{T}$ \\
\hline Carlow, Ireland & 52.859 & -6.918 & 59 & 824 & 9.4 & 2004-2006 & M. Jones; G. Lanigan & $\mathrm{L}$ \\
\hline Doulun, China & 42.046 & 116.280 & 1350 & 399 & 3.3 & 2005-2006 & Shiping Chen & $L$ \\
\hline Foulum, maize, Denmark & 56.484 & 9.587 & 51 & 712 & 8.0 & 2005 & J. Olesen; K. Schelde & $\mathrm{T}$ \\
\hline Gebesee, Germany & 51.100 & 10.914 & 162 & 492 & 9.6 & 2004-2006 & C. Rebmann, W. Kutsch & $\mathrm{T}$ \\
\hline Grignon, France & 48.844 & 1.952 & 125 & 600 & 11.1 & $2005-2006$ & P. Cellier & $\mathrm{T}$ \\
\hline Haller, PA, USA & 48.860 & -77.840 & 352 & 974 & 9.7 & 2003 & R. H. Skinner & $\mathrm{L}$ \\
\hline Klingenberg, Germany & 50.893 & 13.522 & 480 & 850 & 7.0 & 2004-2006 & C. Bernhofer; T. Gruenwald & $\mathrm{T}$ \\
\hline Lamasquère, France, irrigated & 43.493 & 1.237 & 180 & 690 & 13.3 & 2005 & E. Ceschia, P. Béziat & $\mathrm{T}$ \\
\hline Langerak, The Netherlands & 52.004 & 4.806 & -1 & 805 & 11.3 & 2005-2006 & E. Moors, J. Elbers, W. Jans & $\mathrm{T}$ \\
\hline Lonzee, Belgium & 50.552 & 4.745 & 165 & 800 & 10.0 & 2004-2006 & C. Moureaux, M. Aubinet & $L$ \\
\hline Mase, Japan, paddy field & 36.054 & 140.027 & 13 & 1200 & 13.7 & $2002-2003$ & A. Miyata & $\mathrm{T}$ \\
\hline Mead, NE, USA, maize, rainfed & 41.180 & -96.440 & 363 & 887 & 9.7 & 2001-2003 & S. Verma, A. Suyker & $\mathrm{L}$ \\
\hline Mead, NE, USA, soybeans, rainfed & 41.180 & -96.440 & 363 & 887 & 9.7 & 2002-2004 & S. Verma, A. Suyker & $L$ \\
\hline $\begin{array}{l}\text { Mead, NE, USA, maize rotation, } \\
\text { irrigated }\end{array}$ & 41.165 & -96.470 & 362 & 887 & 9.7 & $2001-2003$ & S. Verma, A. Suyker & $\mathrm{T}$ \\
\hline Mead, NE, USA, maize, irrigated & 41.165 & -96.477 & 361 & 728 & 10.1 & $2001-2004$ & S. Verma, A. Suyker & $\mathrm{T}$ \\
\hline $\begin{array}{l}\text { Mead, NE, USA, soybeans, } \\
\text { irrigated }\end{array}$ & 41.165 & -96.470 & 362 & 728 & 10.1 & 2002-2004 & S. Verma, A. Suyker & $\mathrm{T}$ \\
\hline Molenweg, The Netherlands & 51.650 & 4.639 & 1 & 800 & 9.8 & 2005 & E. Moors, J. Elbers & $\mathrm{T}$ \\
\hline Oensingen, Switzerland & 47.286 & 7.734 & 452 & 1100 & 9.0 & 2005 & N. Buchmann; W. Eugster & $\mathrm{T}$ \\
\hline Ponca City, OK, USA, winter wheat & 36.767 & -97.133 & 310 & 866 & 14.8 & 1997 & S. Verma & $L$ \\
\hline Risbyholm, Denmark & 51.530 & 12.097 & 10 & 575 & 9.0 & 2004-2005 & H. Soegaard & $\mathrm{T}$ \\
\hline Rosemount, MN, USA & 44.714 & -93.090 & 260 & 799 & 6.8 & 2004-2005 & T. Griffis, J. Baker & $\mathrm{L}$ \\
\hline \multicolumn{9}{|l|}{ Extensively managed grasslands } \\
\hline Alinya, Spain & 42.152 & 1.449 & 1770 & 669 & 13.0 & $2003-2005$ & M. J. Sanz, C. Gimeno & $L$ \\
\hline Amplero, Italy & 41.867 & 13.633 & 884 & 1365 & 10.0 & 2003-2005 & M. Balzarolo & $\mathrm{L}$ \\
\hline Atquasuk, AK, USA ${ }^{2}$ & 70.470 & -157.409 & $\mathrm{~N} / \mathrm{A}$ & 127 & NA? & 1999-2006 & W. Oechel & $\mathrm{T}$ \\
\hline Audubon Ranch, AZ, USA & 31.591 & -110.510 & 985 & 382 & 16.0 & $2002-2006$ & T. Meyers & $\mathrm{L}$ \\
\hline Barrow, AK, USA ${ }^{2}$ & 71.323 & -156.626 & 1 & 124 & -12.5 & 1998-2002 & W. Oechel & $\mathrm{T}$ \\
\hline Batavia Prairie, IL, USA & 41.841 & -88.241 & 226 & 921 & 10.5 & 2005-2006 & R. Matamala & $\mathrm{L}$ \\
\hline Bily Kriz, Czech Republic & 49.495 & 18.545 & 855 & 1200 & 5.5 & 2004-2006 & M. Marek, R. Czerny & $\mathrm{T}$ \\
\hline Brookings, SD, USA & 44.311 & -96.798 & 495 & 550 & 5.8 & 2004-2006 & T. Meyers, T. Gilmanov, M. Heuer & $\mathrm{L}$ \\
\hline Bugacpuszta, Hungary & 46.691 & 19.601 & 113 & 562 & 10.4 & 2003-2006 & Z. Nagy, K. Pinter & $\mathrm{L}$ \\
\hline Canaan Valley, WV, USA & 39.063 & -79.421 & 988 & 900 & 8.2 & 2004 & T. Meyers & $\mathrm{L}$ \\
\hline Cheyenne, WY, USA & 41.183 & -104.900 & 1910 & 397 & 7.2 & $1997-1998$ & J. Morgan & $\mathrm{L}$ \\
\hline Cottonwood, SD, USA & 43.950 & -101.847 & 735 & 447 & 7.7 & 2004-2006 & T. Meyers, A. Detwiler, K. Brehe & L \\
\hline $\begin{array}{l}\text { Central Plains Experimental } \\
\text { Range, CO, USA }\end{array}$ & 40.683 & -104.750 & 1660 & 332 & 9.2 & $2001-2004$ & J. Morgan & $L$ \\
\hline Doulun, China & 42.047 & 116.284 & 1350 & 399 & 3.3 & 2006 & Shiping Chen & L \\
\hline Duke grassland, NC, USA & 35.971 & -79.090 & 163 & 1145 & 15.5 & $2001-2005$ & G. Katul, P. C. Stoy, K. A. Novick & L \\
\hline Fort Peck, MT, USA & 48.308 & -105.101 & 634 & 310 & 7.7 & $2000-2006$ & T. Meyers & $L$ \\
\hline Fort Reno, OK, USA & 35.557 & -98.017 & 421 & 870 & 14.9 & 2005 & M. Torn, D. Billesbach & L \\
\hline Freeman Ranch, TX, USA & 29.930 & -98.010 & 244 & 959 & 19.4 & 2004 & J. Heilman & L \\
\hline Goodwin Creek, MS, USA & 34.250 & -89.970 & 70 & 1455 & 15.7 & 2002-2006 & T. Meyers & L \\
\hline
\end{tabular}


Table 1. Continued.

\begin{tabular}{|c|c|c|c|c|c|c|c|c|}
\hline Site & Latitude & Longitude & Elevation & PCPN & $T_{\text {year }}$ & Years & Investigator(s) & Method $^{1}$ \\
\hline Grillenburg, Germany & 50.951 & 13.514 & 380 & 853 & 7.2 & 2004-2006 & C. Bernhofer, T. Gruenwald & L \\
\hline Gudmundsen Ranch, NE, USA & 42.069 & -101.407 & 1081 & 560 & 7.9 & 2006 & D. Billesbach & L \\
\hline Haibei, China & 37.617 & 101.317 & 3250 & 561 & -1.7 & 2002-2003 & T. Kato & $\mathrm{T}$ \\
\hline Ivotuk, AK, USA & 68.486 & -155.750 & 550 & 250 & -9.0 & 2004-2006 & W. Oechel & $\mathrm{T}$ \\
\hline Jornada, NM, USA & 32.600 & -106.750 & 1320 & 272 & $\mathrm{~N} / \mathrm{A}$ & 2000-2001 & W. Dugas, P. Mielnick & L \\
\hline Karnap, Uzbekistan & 40.000 & 65.500 & 310 & 237 & 14.6 & 2001 & M. Nasyrov, N. Saliendra & L \\
\hline Kendall, AZ, USA & 31.737 & -109.942 & 1531 & 356 & 17.0 & 1999-2006 & W. Emmerich & L \\
\hline Khakasia, Russia & 54.773 & 90.002 & 430 & 388 & 2.2 & 2002-2004 & L. Belelli & L \\
\hline Khakasia 3, Russia & 54.705 & 89.078 & 401 & 384 & 2.3 & 2004 & L. Belelli & $\mathrm{T}$ \\
\hline Kherlenbayan-Ulaan, Mongolia & 47.214 & 108.737 & 1235 & 196 & 1.2 & 2003 & Shenggong Li & L \\
\hline Laqueuille, France & 45.643 & 2.736 & 1040 & 1013 & 8.6 & 2002-2006 & J.-F. Soussana, V. Allard & L \\
\hline Lethbridge, Canada & 49.709 & -112.940 & 960 & 378 & 6.4 & 1998-2002 & L. Flanagan & L \\
\hline Little Washita, OK, USA & 34.967 & -97.983 & 335 & 750 & 16.3 & 1997-1998 & T. Meyers & L \\
\hline Malga Arpaco, Italy & 46.117 & 11.703 & 1699 & 1200 & 6.3 & 2003-2004 & A. Raschi & L \\
\hline Mandan, ND, USA & 46.767 & -100.917 & 518 & 404 & 5.0 & 1999-2001 & A. Frank & L \\
\hline Matra, Hungary & 47.842 & 19.726 & 350 & 622 & 10.2 & 2004-2005 & Z. Tuba, Z. Nagy, J. Balogh & T \\
\hline Miles City, MT, USA & 46.300 & -105.967 & 719 & 343 & 7.9 & 2000-2001 & M. Haferkamp & L \\
\hline Monte Bondone, Italy & 46.016 & 11.047 & 1550 & 1189 & 5.5 & 2003-2006 & D. Gianelle & $\mathrm{T}$ \\
\hline Neal Smith, IA, USA & 41.558 & -93.296 & 280 & 826 & 9.1 & 2005 & J. Prueger & L \\
\hline Oensingen, Switzerland & 47.286 & 7.732 & 452 & 1100 & 9.0 & 2002-2003 & C. Ammann, J. Fuhrer & L \\
\hline Rannels Ranch, KS, USA & 39.139 & -96.523 & 324 & 840 & 12.9 & 1998-1999 & C. Owensby & L \\
\hline Rigi-Seebodenalp, Switzerland & 47.058 & 8.457 & 1025 & 1327 & 7.3 & 2003 & W. Eugster, N. Rogiers & L \\
\hline Rondonia, Brazil & -10.762 & -62.357 & 306 & 1664 & 23.9 & 1999 & M. Waterloo, A. Manzi & L \\
\hline Santarem, Brazil & -3.012 & -54.537 & $\mathrm{~N} / \mathrm{A}$ & $\mathrm{N} / \mathrm{A}$ & $\mathrm{N} / \mathrm{A}$ & 2001-2002 & D. Fitzjarrald & L \\
\hline Shidler, OK, USA & 36.933 & -96.683 & 356 & 942 & 14.8 & 1997-1999 & S. Verma, A. Suyker & L \\
\hline Shortandy, Kazakhstan & 51.667 & 71.000 & 367 & 323 & 1.6 & 1998-2001 & $\begin{array}{l}\text { K. Akshalov, N. Saliendra, D. A. } \\
\text { Johnson }\end{array}$ & L \\
\hline Temple, TX, USA & 31.100 & -97.333 & 219 & 878 & 19.6 & 1998-1999 & W. Dugas, P. Mielnick & L \\
\hline Tojal, Portugal & 38.477 & -8.025 & 190 & 669 & 15.5 & 2004-2006 & C. Pio, L. Aires & L \\
\hline Viara Ranch, CA, USA & 38.407 & -120.951 & 129 & 500 & 15.9 & 2001-2006 & D. Baldocchi & L \\
\hline Walnut River, KS, USA & 37.521 & -96.855 & 408 & 1030 & 13.1 & 2002-2004 & R. Coulter, D. Cook & L \\
\hline Woodward, OK, USA & 36.600 & -99.583 & 630 & 586 & 14.3 & 1997-2002 & P. Sims, J. Bradford & L \\
\hline Xilinhot grazed, China & 43.554 & 116.671 & 1250 & 360 & 2.0 & 2006 & Shiping Chen & L \\
\hline Xilinhot, fenced, China & 43.546 & 116.678 & 1250 & 360 & 2.0 & 2006 & Shiping Chen & $\mathrm{T}$ \\
\hline Xilinhot, typical fenced, China & 44.134 & 116.329 & 1030 & 290 & 2.0 & 2004-2006 & Guangsheng Zhou & $\mathrm{T}$ \\
\hline \multicolumn{9}{|l|}{ Intensively managed grasslands } \\
\hline Cabauw extension, the Netherlands & 51.954 & 4.903 & -1 & 786 & 9.8 & 2005 & E. Moors, J. Elbers & T \\
\hline Cabauw, the Netherlands & 51.967 & 4.917 & -1 & 800 & 10.0 & 2003 & A. Hensen & $\mathrm{T}$ \\
\hline Cabauw, the Netherlands & 51.971 & 4.927 & -1 & 786 & 9.8 & 2004-2006 & E. Moors, J. Elbers, F. Bosveld & $\mathrm{T}$ \\
\hline Carlow, grassland, Ireland & 52.850 & -6.900 & 50 & 804 & 10.1 & 2003 & M. Jones, G. Lanigan & L \\
\hline Dripsey, grass, Ireland & 51.919 & -8.751 & 187 & 1450 & 9.5 & 2002-2005 & G. Kiely, P. Leahy & $\mathrm{T}$ \\
\hline Easter Bush, United Kingdom & 55.867 & -3.200 & 190 & 890 & 8.0 & 2003-2004 & M. Sutton & L \\
\hline Haarweg, the Netherlands & 51.970 & 5.630 & 7 & 760 & 9.5 & 2002 & A. Jacobs & $\mathrm{T}$ \\
\hline Haastrecht, the Netherlands & 52.004 & 4.806 & -2 & 786 & 9.8 & 2003 & E. Moors & T \\
\hline Haller, PA, USA & 40.862 & -77.840 & 352 & 974 & 9.7 & 2003-2005 & R. H. Skinner & L \\
\hline Hegyhátsál, Hungary & 46.950 & 16.650 & 248 & 759 & 8.9 & 1999 & Z. Barcza, L. Haszpra & $\mathrm{T}$ \\
\hline Horstermeer, the Netherlands & 52.029 & 5.068 & -2 & 797 & 9.8 & 2004-2006 & A. J. Dolman & T \\
\hline Jokioinen, Finland & 60.899 & 23.514 & 104 & 581 & 3.9 & 2002 & A. Lohila, T. Laurila & L \\
\hline Lacombe, Canada & 52.436 & -113.808 & 871 & 446 & 2.1 & 2003 & V. S. Baron & L \\
\hline Laqueuille, France & 45.643 & 2.736 & 1040 & 1013 & 8.6 & 2002-2006 & J.-F. Soussana, V. Allard & L \\
\hline Lelystad, the Netherlands & 52.500 & 5.500 & 0 & 780 & 10.0 & 2004 & A. Hensen & L \\
\hline Lille Valby, Denmark & 55.700 & 12.117 & 15 & 1119 & 8.5 & 2004-2006 & E. Dellwik & L \\
\hline Neustift, Austria & 47.117 & 11.317 & 970 & 850 & 6.3 & 2001-2006 & G. Wohlfahrt & L \\
\hline Oensingen, Switzerland & 47.283 & 7.733 & 485 & 1100 & 9.0 & 2002-2006 & C. Ammann; J. Fuhrer & L \\
\hline
\end{tabular}


Table 1. Continued.

\begin{tabular}{|c|c|c|c|c|c|c|c|c|}
\hline Site & Latitude & Longitude & Elevation & PCPN & $T_{\text {year }}$ & Years & Investigator(s) & Method $^{1}$ \\
\hline \multicolumn{9}{|l|}{ Shrublands and savanna } \\
\hline Burns, OR, USA & 43.483 & -119.717 & 1380 & 283 & 7.6 & $1995-2001$ & T. Svejcar & L \\
\hline Dubois, ID, USA & 44.267 & -112.133 & 1700 & 302 & 6.2 & $1996-2001$ & D. A. Johnson, N. Z. Saliendra & L \\
\hline Howard Springs, Australia & -12.329 & 131.000 & 38 & 1824 & 25.9 & 2002-2005 & J. Beringer & L \\
\hline Karrykul, Turkmenistan & 38.600 & 58.400 & 90 & 148 & 15.6 & $1998-2000$ & $\begin{array}{l}\text { M. Durikov, N. Saliendra, D. A. } \\
\text { Johnson }\end{array}$ & L \\
\hline Kubuqi, China & 40.381 & 108.549 & 1160 & 180 & 7.5 & 2006 & Shiping Chen & L \\
\hline Santa Rita, AZ, USA & 31.821 & -110.866 & 1120 & 330 & 17.6 & 2004-2006 & R. Scott & T \\
\hline Sao Paulo, Brazil & -21.619 & -47.650 & $\mathrm{~N} / \mathrm{A}$ & 953 & $\mathrm{~N} / \mathrm{A}$ & $2001-2002$ & H. da Rocha & T \\
\hline Skukuza, South Africa & -24.983 & 31.600 & 263 & 561 & 21.6 & $2001-2003$ & N. Hanan & L \\
\hline Sky Oaks, CA, USA, old stand & 33.374 & -116.623 & 1394 & 491 & 12.2 & $1997-2006$ & W. Oechel & L \\
\hline Sky Oaks, CA, USA, young stand & 33.377 & -116.623 & 1429 & 491 & 12.2 & $1997-2001$ & W. Oechel & T \\
\hline Tonzi Ranch, CA, USA & 38.432 & -120.966 & 177 & 559 & 15.4 & $2002-2006$ & D. Baldocchi & T \\
\hline \multicolumn{9}{|l|}{ Wetlands } \\
\hline Cherskii, Russia & 68.615 & 161.339 & 4 & 200 & -12.5 & 2003-2004 & C. Corradi & $\mathrm{T}$ \\
\hline CzechWet, Czech Republic & 49.025 & 14.772 & 420 & 740 & 7.2 & 2006 & M. Marek; D. Janous & T \\
\hline Dongtan marsh 1, China & 31.517 & 121.961 & 4 & 2192 & 15.7 & 2005 & Bin Zhao; Haiqiang Guo & $\mathrm{T}$ \\
\hline Dongtan marsh 2, China & 31.585 & 121.903 & 4 & 2074 & 15.7 & 2005 & Bin Zhao; Guo Haiqiang & T \\
\hline Dongtan marsh 3, China & 31.517 & 121.972 & 4 & 2190 & 15.5 & 2005 & Bin Zhao; Haiquang Guo & T \\
\hline Kaamanen wetland, Finland & 69.141 & 27.295 & 155 & 395 & -1.3 & $2000-2006$ & T. Laurila; M. Aurela & $\mathrm{T}$ \\
\hline PolWet, Poland & 52.762 & 16.309 & 54 & 550 & 8.1 & 2004 & M. Urbaniak, J. Olejnik & $\mathrm{T}$ \\
\hline Siikaneva, Finland & 61.833 & 24.193 & $\mathrm{~N} / \mathrm{A}$ & 713 & 3.0 & $2004-2006$ & M. Aurela & T \\
\hline Tadham Moore, United Kingdom & 51.207 & -2.829 & 3 & 750 & 11.1 & 2001 & R. Harding, C. Lloyd & T \\
\hline
\end{tabular}

${ }^{1}$ Method on net flux partitioning into photosynthesis and respiration: $\mathrm{L}$ indicates light-response function analysis; $\mathrm{T}$, nighttime temperature dependence.

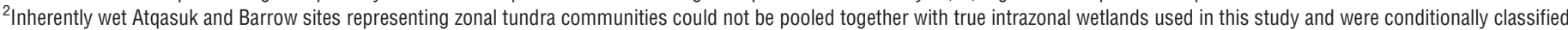
as "extensive grasslands." Tundra would be separated into a distinct category if sufficient data were available.

partitioned into gross primary productivity $\left(P_{\mathrm{g}}\right)$ and ecosystem respiration $\left(R_{\mathrm{e}}\right)$ components with the use of light-response function methods (Gilmanov et al. 2003a, 2003b, 2004, 2005, 2006, 2007). These data were combined with an additional 46 nonforest sites (Table 1, method T) from the FLUXNET La Thuile data set (Agarwal et al. 2008) that were partitioned into $P_{\mathrm{g}}$ and $R_{\mathrm{e}}$ components with the use of the temperature-response methods (Reichstein et al. 2005). In most cases, we used daily $P_{\mathrm{g}}$ and $R_{\mathrm{e}}$ estimates directly from the La Thuile data set, though sometimes it was necessary to correct spurious values of daily gross primary production that were occasionally generated by the nighttime temperature-response method owing to the substantial scatter that may exist in instantaneous $\mathrm{CO}_{2}$ flux measurements (cf. Stoy et al. 2006).

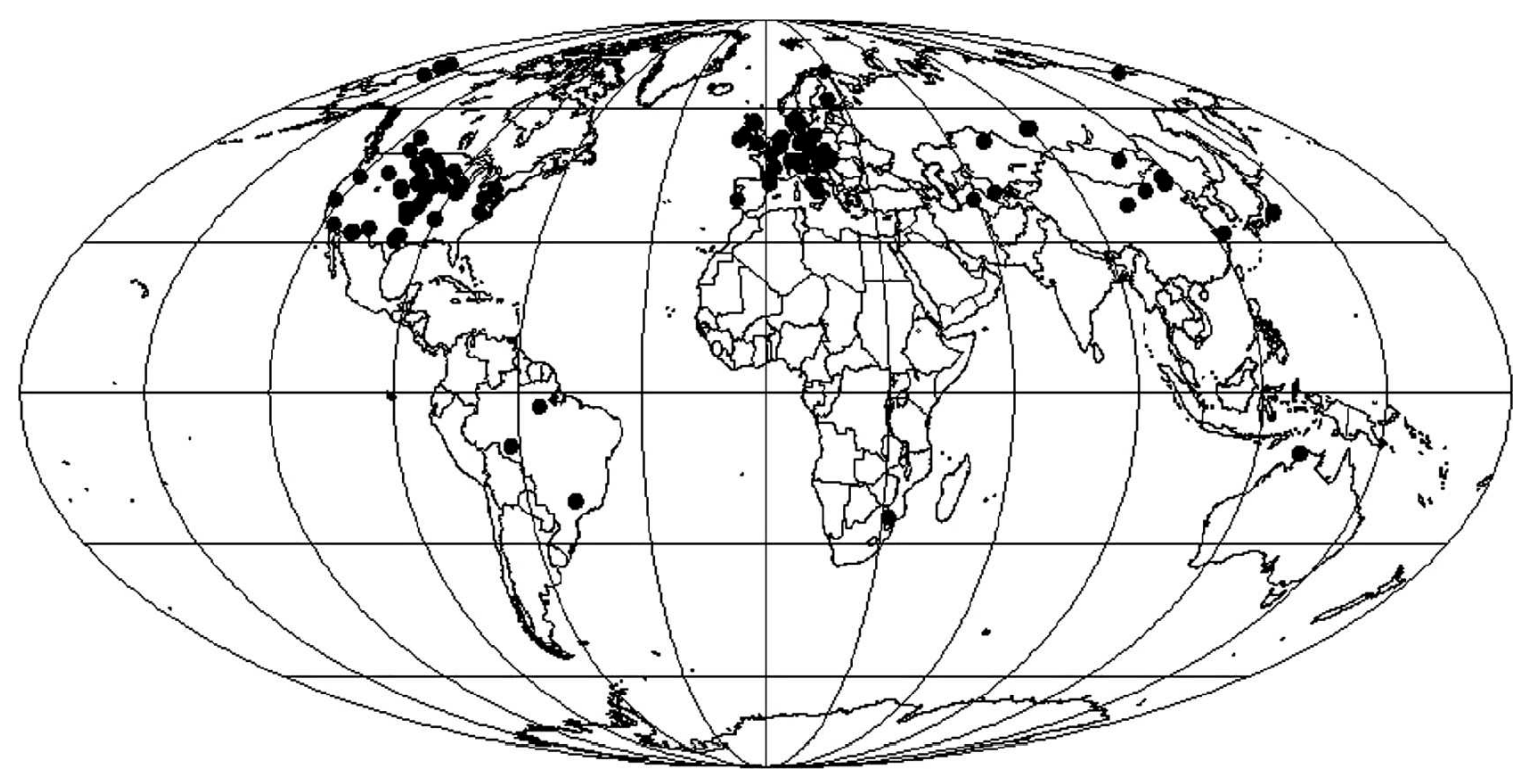

Figure 1. Geographical distribution of the 118 nonforest flux-tower sites considered in this study. 
In total, tower sites included in our analysis represented 316 site-years of measurements during the 1997-2006 period (Table 1). They are grouped into the following categories: extensively managed grasslands (ungrazed or lightly grazed, uncut or cut occasionally), intensively managed grasslands (regularly cut, grazed, fertilized, irrigated, etc.), croplands, shrublands/savannas, and wetlands. The geographic distribution of sites is illustrated in Figure 1.

\section{Net Tower Flux $F_{\mathrm{c}}$ Partitioning into Photosynthesis $\boldsymbol{P}_{\mathrm{g}}$ and Respiration $\boldsymbol{R}_{\mathrm{e}}$}

Analysis of flux-tower measurements requires processing algorithms (Lee et al. 2004; Burba and Anderson 2007; Baldocchi 2008a) that describe the net result of interacting ecosystem components that absorb $\mathrm{CO}_{2}$, mostly photosynthetic assimilation by autotrophic organisms and those that release $\mathrm{CO}_{2}$ (metabolic $\mathrm{CO}_{2}$ production, $R_{\mathrm{e}}$, is the major component of $\mathrm{CO}_{2}$ efflux in most ecosystems where geologic production of $\mathrm{CO}_{2}$ does not predominate). Because photosynthesis and respiration respond rather differently to major environmental drivers (e.g., Thornley and Johnson 2000), partitioning of tower-based $F_{c}$ data into photosynthetic assimilation and ecosystem respiration components is recognized as a necessary step in the postprocessing of net flux data for use in predictive modeling of ecosystem carbon cycling (Gilmanov et al. 2003b, 2004, 2005; Reichstein et al. 2005; Wohlfahrt et al. 2005; Gilmanov et al. 2006; Stoy et al. 2006; Gilmanov et al. 2007).

With the use of the ecophysiological sign convention (positive flux from atmosphere to ecosystem), and excluding plants with CAM-type metabolism, $P_{\mathrm{g}}$ used in this study was obtained as a sum of daytime $F_{\mathrm{c}}$ and daytime ecosystem respiration $\left(R_{\mathrm{d}}\right)$, minus the rate of change of $\mathrm{CO}_{2}$ storage in the atmospheric layer between the soil surface and the $\mathrm{CO}_{2}$ sensor at the tower (Gilmanov and WORLDGRASSAGRIFLUX Data Set Participants 2007). When estimates of the storage term were not available (e.g., for communities with low canopy height and sufficient turbulent transport) the gross productivity was approximated as

$$
P_{\mathrm{g}}(t)=\left\{\begin{array}{cc}
F_{\mathrm{c}}(t)+R_{\mathrm{d}}(t), & Q(t)>0 \\
0, & Q(t)=0
\end{array}\right.
$$

where $Q(t)$ is the intensity of photosynthetically active radiation (Gilmanov et al. 2004).

Because direct measurements of the $R_{\mathrm{d}}$ are quite difficult to make, two main approaches of its indirect estimation (leading to the two major methods of net flux partitioning into photosynthesis and respiration components) were used. The first approach establishes the relationship of nighttime respiration $\left(R_{\mathrm{n}}\right)$,

$$
R_{\mathrm{n}}(t)=\left\{\begin{array}{cc}
F_{\mathrm{c}}(t), & Q(t)=0 \\
0, & Q(t)>0
\end{array}\right.
$$

to environmental drivers affecting it (e.g., soil temperature $\left[T_{\mathrm{s}}\right]$ ) and uses these relationships to estimate $R_{\mathrm{d}}$. This approach has been widely used for forest-type ecosystems (Goulden et al. 1996) and was used in this study for the first round of networklevel aggregation of the raw 30-min data into daily gross primary productivity and ecosystem respiration values (http:// www.fluxdata.org/DataInfo/).

The second approach involves obtaining estimates of $R_{\mathrm{d}}$ through identification of the respiration term in the ecosystemscale light-response functions describing relationships of the daytime $F_{\mathrm{c}}$ to photon flux density, $Q$, leaf area index $(L), T_{\mathrm{s}}$, water content of the soil $\left(W_{s}\right)$, air relative humidity $(\mathrm{RH})$, and other factors. In general, light-response functions include rather complicated analytical or algorithmic expressions (e.g., those suggested by Thornley and Johnson 2000), taking into account most of the major ecophysiological parameters of photosynthesis (quantum yield $[\alpha]$, maximum photosynthesis $\left[A_{\max }\right]$, convexity of the light response $[\theta]$, and $L)$. When fully expanded, these expressions can require several lines of printed text. At the other end of the complexity spectrum lie simple $F_{c}(Q)$ relationships such as the ramp function by Blackman (1905), Mitscherlich's saturated exponent (1909), and the rectangular hyperbola by Tamiya (1951), the latter being a nearly standard approach to light-response fitting at the early stages of flux-tower data analysis (Ruimy et al. 1995). These simple models are convenient and, in some cases, fit observed data well; however, they share the major drawback of lacking the ability to describe light-response patterns of varying convexity (curvature).

Under the widely accepted ecophysiological framework, the convexity of the light response is represented by the fraction of diffusion resistance to the total (diffusion + carboxylation) resistance to carbon transport: $\theta=\rho_{\mathrm{d}} /\left(\rho_{\mathrm{d}}+\rho_{\mathrm{x}}\right.$; Thornley and Johnson 2000). If the differences in leaf morphology and biochemistry in different plant groups are taken into account (e.g., $\mathrm{C}_{3}$ vs. $\mathrm{C}_{4}$ photosynthesis types), the ability to describe light-response curves of different convexity seems to be a necessary requirement for an adequate light-response function model. Our experience with quantification of the tower-based light-response data from a wide range of nonforest ecosystems led us to use the nonrectangular hyperbolic model (Rabinowich 1951; Thornley and Johnson 2000):

$$
\begin{aligned}
& F_{\mathrm{c}}\left(Q ; \alpha, A_{\max }, \theta, r_{\mathrm{d}}\right)= \\
& \frac{1}{2 \theta}\left(\alpha Q+A_{\max }-\sqrt{\left(\alpha Q+A_{\max }\right)^{2}-4 \alpha A_{\max } \theta Q}\right)-r_{\mathrm{d}},
\end{aligned}
$$

where $Q$ denotes photon flux density, $\alpha$ is the quantum yield, $A_{\max }$ is maximum gross photosynthesis, $\theta$ is the convexity parameter of the light-response curve, and $r_{\mathrm{d}}$ is daytime ecosystem respiration rate for days when solar radiation is the major driver of daytime $\mathrm{CO}_{2}$ exchange. This model provides a powerful and flexible tool to describe light response at the various nonforest tower sites (Gilmanov et al. 2003a, 2003b, 2004, 2005, 2006, 2007).

Under semiarid and arid conditions, when significant warming of the soil in the afternoon period is observed, the pattern of data points on the light-response plane $\left\{Q, F_{c}\right\}$ is often characterized by a hysteresis-like loop with the morning branch of the light-response curve lying above the afternoon branch. In such cases, these light-response patterns were effectively described by the modified nonrectangular hyperbolic model (Gilmanov et al. 2003a): 
$F_{\mathrm{c}}\left(Q, T_{s} ; \alpha, A_{\max }, \theta, r_{\mathrm{d}}\right)=$

$\frac{1}{2 \theta}\left(\alpha Q+A_{\max }-\sqrt{\left(\alpha Q+A_{\max }\right)^{2}-4 \alpha A_{\max } \theta Q}\right)-r_{0} e^{k_{\mathrm{T}} T_{\mathrm{s}}}$,

where the daytime respiration term $r_{\mathrm{d}}$ of Equation [3] is modified to $r_{0} e^{k_{\mathrm{T}} T_{\mathrm{s}}}$ to represent an exponential increase of respiration with soil temperature, $T_{\mathrm{s}}$ and $k_{\mathrm{T}}$ and $r_{0}$ are empirical parameters estimated by fitting Equation 4 to the daytime data $\left\{Q\left(t_{\mathrm{i}}\right), T_{\mathrm{s}}\left(t_{\mathrm{i}}\right), F_{\mathrm{c}}\left(t_{\mathrm{i}}\right)\right\}$, and $t_{\mathrm{i}}$ is time between the sunrise and sunset, $t_{\mathrm{r}} \leq t_{\mathrm{i}} \leq t_{\mathrm{s}}$. For days described by Equation 4 , average daytime respiration rate, $r_{\mathrm{d}}$, was calculated as

$$
r_{\mathrm{d}}=\frac{r_{0}}{t_{\mathrm{s}}-t_{\mathrm{r}}} \int_{t_{\mathrm{r}}}^{t_{\mathrm{s}}} e^{k_{\mathrm{T}} T_{\mathrm{s}}(t)} d t .
$$

In cases where vapor pressure deficit (VPD) effect limits $\mathrm{CO}_{2}$ uptake, this approach would tend to overestimate $r_{\mathrm{d}}$, and consequently $P_{\mathrm{g}}$, when a decline of $P_{\mathrm{g}}$ may be just as likely. Numerical fitting of parameters $\alpha, A_{\max }, \theta, r_{\mathrm{d}}$, or $r_{0}$ and $k_{\mathrm{T}}$ of Equations 3 or 4 was achieved using procedures from the Global Optimization Package (Loehle Enterprises 2007) available under the Mathematica software system (Wolfram Research 2009). It should be emphasized that to avoid serious errors in estimating light-response parameters resulting from fitting equations to data pooled across over several days (as sometimes can be seen in publications on the subject, e.g., Ruimy et al. 1995; Zhang et al. 2006; Zhao et al. 2006), only single-day data sets $\left\{Q\left(t_{\mathrm{i}}\right)\right.$, $\left.T_{\mathrm{s}}\left(t_{\mathrm{i}}\right), F_{\mathrm{c}}\left(t_{\mathrm{i}}\right)\right\}$ were used in this study to identify the light curves and the light-temperature response surfaces of $\mathrm{CO}_{2}$ exchange.

It should also be noted that parameters obtained by fitting Equations 3 or 4 to flux-tower data sets are ecosystem-scale parameters referring to a ground unit (e.g., per $1-\mathrm{m}^{2}$ ground surface) and should be distinguished from leaf-level light-response parameters used in physiological studies, which correspond to units of leaf area (e.g., $A_{L, \max }, \alpha_{L}$, etc.). Only under special conditions (monoculture with convexity $\theta=0$ ), is photosynthetic capacity per unit ground area $\left(A_{\max }\right)$ equal to the product of photosynthetic capacity per unit leaf area $\left(A_{L, \max }\right)$ and the leaf area index $(L): A_{\max }=A_{L, \max } \times L$ (cf. Thornley and Johnson 2000).

For measurement days that allow identification of parameters of models [3] or [4], total $R_{\mathrm{d}}$ was calculated as the product of average $r_{\mathrm{d}}$ and the length of the daylight period:

$$
R_{\mathrm{d}}=r_{\mathrm{d}}\left(t_{\mathrm{s}}-t_{\mathrm{r}}\right) \text {. }
$$

For days with daytime data inappropriate for light-response analysis, parameters $k_{\mathrm{T}}$ and $r_{0}$ were estimated by fitting an exponential equation $F_{\mathrm{c}}=r_{0} e^{k_{\mathrm{T}} T_{\mathrm{s}}}$ to the nighttime data, $\left\{T_{\mathrm{s}}\left(t_{\mathrm{i}}\right), F_{\mathrm{c}}\left(t_{\mathrm{i}}\right)\right\}_{Q\left(t_{\mathrm{i}}\right)=0}$.

Eventually, total daily gross primary production $\left(P_{\mathrm{g}}\right)$ was obtained as the sum of daytime respiration total $\left(R_{\mathrm{d}}\right)$ and the daytime net flux integral, $P_{\mathrm{d}}=\int_{t_{\mathrm{r}}}^{t_{\mathrm{s}}} F_{\mathrm{c}}(t) d t P_{\mathrm{d}}=\int_{t_{\mathrm{r}}}^{t_{\mathrm{s}}} F_{\mathrm{c}}(t) d t$ :

$$
P_{\mathrm{g}}=P_{\mathrm{d}}+R_{\mathrm{d}}
$$

Gap-filling of $P_{\mathrm{g}}$ and $R_{\mathrm{e}}$ values for days with missing measurements was achieved with the use of various methods characterized in the recent review by Moffat et al. (2007), with particular emphasis on 1) extrapolation of parameters of lightand temperature-response functions to days with missing flux measurements, calculations of fluxes at the 30 -min time scale, and estimation of daily $P_{\mathrm{g}}$ and $R_{\mathrm{e}}$ values as integrals of corresponding 30-min estimates; and 2) nonlinear regressions of daily $P_{\mathrm{g}}$ and $R_{\mathrm{e}}$ values from daily aggregated values of predictors such as photosynthetically active radiation, air and soil temperature, soil water content, etc.

\section{Seasonal Patterns of Parameter Dynamics}

Numerical estimation of the major light-response parameters on a daily basis, i.e., obtaining the values $\alpha, A_{\max }, \theta, r_{\mathrm{d}}$ for as many days $t$ as allowed by the quality and quantity of the data, permits evaluation of time-functions $\alpha(t), A_{\max }(t), \alpha(t), r_{\mathrm{d}}(t)$ characterizing seasonal patterns of the dynamics of these parameters. These patterns are revealed most clearly through smoothing of the empirical time series of the parameter estimates. In this study, we used one of the simplest and easily interpretable methods-calculation of the mean parameter value and its standard error, e.g., $\left\{\bar{\alpha}_{j}, s_{\bar{\alpha}_{j}}\right\},\left\{\bar{A}_{\max }, j, s_{\bar{A}_{\max }, j}\right\}$, etc. for every calendar week $j$ of the year of observations $(j 1, \ldots, 52\}$. Using weekly average values instead of individual daily estimates is effective for comparison among ecosystems and years, particularly for such parameters as quantum yield $(\alpha)$, which exhibits large day-to-day variability.

\section{Seasonal Dynamics and Annual Budgets of Annual Gross Primary Production (GPP), Annual Total Ecosystem Respiration (RE), and Net Ecosystem $\mathrm{CO}_{2}$ Exchange (NEE)}

Estimated values of $P_{\mathrm{g}}(t)$ and $R_{\mathrm{e}}(t)$ for the year-round or observation period were integrated across 365 days (or across measurement season when no year-round data were available) to obtain annual (seasonal) totals of GPP and RE. Integrated NEE total to day $t, \operatorname{IntNEE}(t)$, was calculated by integrating daily values of $F_{\mathrm{c}}(t)=P_{\mathrm{g}}(t)-R_{\mathrm{e}}(t)$. NEE was calculated as the difference between GPP and RE.

\section{Ecosystem-Scale Light-Use Efficiency}

Comparative physiological studies at the leaf, individual, or population level commonly calculate the light-use efficiency of gross photosynthesis $\left(P_{\mathrm{g}}\right)$ with respect to absorbed photosynthetically active radiation, $Q_{\mathrm{a}}$, resulting in a gross physiological light-use efficiency coefficient (Larcher 1995):

$$
\varepsilon_{\text {phys }}=\frac{P_{\mathrm{g}}}{Q_{\mathrm{a}}},
$$

where both the photosynthesis $P_{\mathrm{g}}$ and absorbed radiation $Q_{\mathrm{a}}$ are expressed in molar units (e.g., it is convenient to measure $\varepsilon$ in mmol $\mathrm{CO}_{2}$ per mol quanta). However, in comparative ecological studies it is preferable to use the coefficient of gross ecological light-use efficiency (cf. Odum 1959 [p. 54]; Cooper 1970; Austin et al. 1978; Colinvaux 1993):

$$
\varepsilon_{\mathrm{ecol}}=\frac{P_{\mathrm{g}}}{Q},
$$



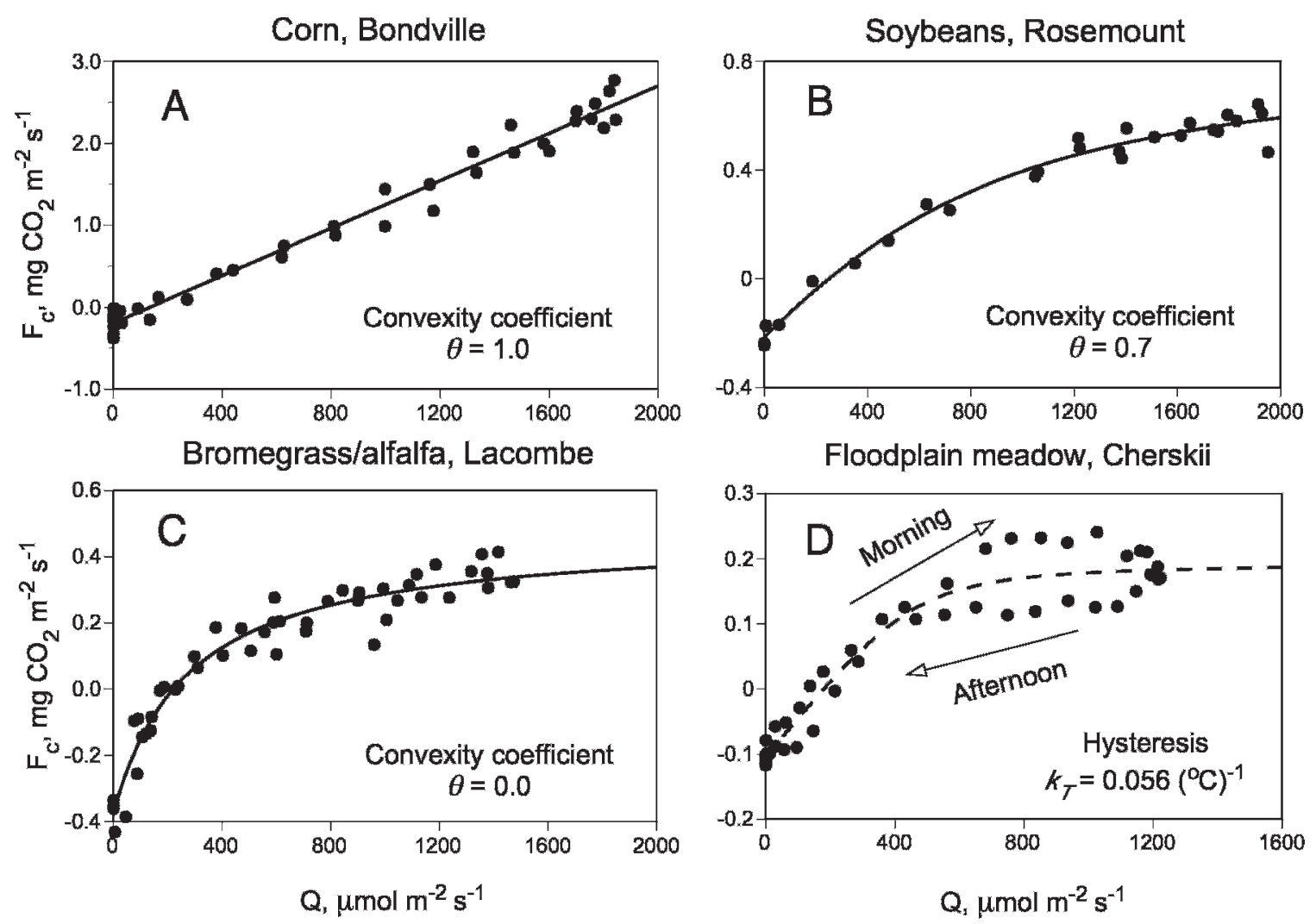

Figure 2. Major types of ecosystem light-response functions: A, linear, convexity $\theta=1$ (maize crop, Bondville, IL, USA, 1999, day 188); B, nonrectangular hyperbolic, convexity $0<\theta<1$ (soybeans, Rosemount, MN, USA, 2004, day 207); C, rectangular hyperbolic, $\theta=0$ (meadow bromegrass/alfalfa, Lacombe, Alberta, Canada, 2003, day 151); D, hysteresis (floodplain meadow, Cherskii, East Siberia, Russia, 2005, day 1900, $\left.k_{\mathrm{T}}=0.056^{\circ} \mathrm{C}^{-1}\right)$.

calculated per unit of total incoming photosynthetically active radiation, Q. Although the physiological light-use efficiency coefficient, $\varepsilon_{\text {phys }}$, characterizes physiological and biochemical parameters (and is often used in studies performed at the unit leaf area or unit of photosynthetically active biomass basis), the ecological light-use efficiency, $\varepsilon_{\text {ecol }}$, as a rule, is calculated per unit ground surface $\left(\mathrm{m}^{-2}, \mathrm{ha}^{-1}\right.$, etc.), and thus also takes into account such ecosystem-level properties as population density, aboveground biomass, and leaf area.

\section{RESULTS AND DISCUSSION}

\section{Light-Response Functions and Parameters}

Within the broad range of climatic conditions and ecosystem types represented in the data set, we observed a variety of patterns of light response. For comparative purposes, it is convenient to distinguish four major categories differentiated in terms of convexity and presence of the hysteresis-like loop on the light-response scatter diagram $\left\{Q, F_{c}\right\}$ (Fig. 2). In the latter case, plotting the 3-D scatter diagram of the diurnal dynamics of the measurement data and of the response surface $F_{c}\left(Q, T_{\mathrm{s}}\right)$ (Equation 4) fitted to them provides a partial explanation of the loop on the 2-D $\left\{Q, F_{c}\right\}$ plot caused by the increase of ecosystem respiration with the increase of temperature in the afternoon hours (Fig. 3). For the cases shown in Figures 2 and 3, numerical estimates and statistical characteristics of parameters in Equations 3 and 4 are presented in Tables 2 and 3.

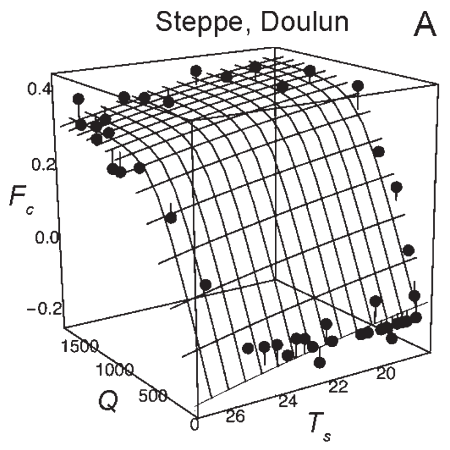

A Sown pasture, Brookings $B$

Wet-dry savanna. Howard C
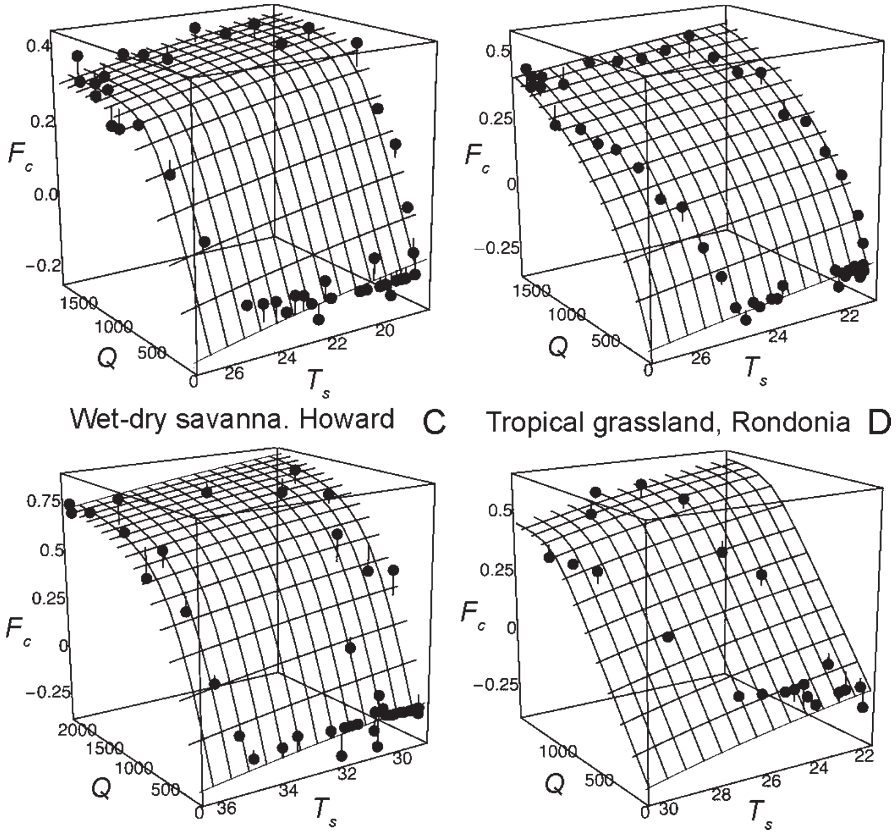

Figure 3. Light-temperature response surfaces fitted by modified nonrectangular Equation 4 for representative days for $\mathbf{A}$, Doulun steppe, China, 2006, day 218; B, Brookings sown pasture, SD, USA, 2005, day 190; C, Howard wet-dry savanna, Australia, 2002, day 34; and D, Rondonia tropical grassland, Brazil, 1999, day 270. 
Table 2. Parameters $\alpha, A_{\max }, \quad r_{\mathrm{d}}$, and $\theta$ from the nonrectangular hyperbolic light-response function $F_{\mathrm{c}}(Q)=(1 / \theta)$ $\left(\alpha Q+A_{\max }-\sqrt{\left.\left(\alpha Q+A_{\max }\right)^{2}-4 \alpha A_{\max } \theta Q\right)}-r_{d}\right.$ for representative days at the Bondville, Rosemount, Lacombe, and Brookings flux-tower stations.

\begin{tabular}{|c|c|c|c|c|}
\hline \multirow[b]{2}{*}{ Statistical characteristics } & \multicolumn{4}{|c|}{ Parameters } \\
\hline & Slope, $\alpha \mathrm{mg} \mathrm{CO} 2 \cdot \mu \mathrm{mol}^{-1}$ & Plateau, $A_{\max } \mathrm{mg} \mathrm{CO}_{2} \cdot \mathrm{m}^{-2} \cdot \mathrm{s}^{-1} \mathrm{Re}$ & Sespiration, $r_{\mathrm{d}} \mathrm{mg} \mathrm{CO}{ }_{2} \cdot \mathrm{m}^{-2} \cdot \mathrm{s}^{-1}$ & Convexity, $\theta$ dimensionless \\
\hline \multicolumn{5}{|c|}{ Maize crop, Bondville, IL, USA, 1999 , day $188 ; R^{2}=0.98 ; \mathrm{SE}=0.158 \mathrm{mg} \mathrm{CO} \cdot \mathrm{m}^{-2} \cdot \mathrm{s}^{-1}$} \\
\hline Estimate & 0.0014 & 3.2 & 0.1936 & 1.0 \\
\hline Standard error & 0.0001 & - & 0.0423 & 0.0012 \\
\hline Student's $t$ & 19.92 & - & 4.58 & 84.20 \\
\hline$P$ level & 0.0000 & - & 0.0000 & 0.0000 \\
\hline \multicolumn{5}{|c|}{ Soybeans, Rosemount, MN, USA, 2004, day $207 ; R^{2}=0.98 ; \mathrm{SE}=0.045 \mathrm{mg} \mathrm{CO} 2 \cdot \mathrm{m}^{-2} \cdot \mathrm{s}^{-1}$} \\
\hline Estimate & 0.0009 & 0.9930 & 0.2002 & 0.6947 \\
\hline Standard Error & 0.0002 & 0.1899 & 0.0221 & 0.3329 \\
\hline Student's $t$ & 4.77 & 5.23 & 9.07 & 2.09 \\
\hline$P$ level & 0.0000 & 0.0000 & 0.0000 & 0.0243 \\
\hline \multicolumn{5}{|c|}{ Sown pasture, Lacombe, Alberta, Canada, 2003, day $151 ; R^{2}=0.94 ; \mathrm{SE}=0.061 \mathrm{mg} \mathrm{CO} 2 \cdot \mathrm{m}^{-2} \cdot \mathrm{s}^{-1}$} \\
\hline Estimate & 0.0026 & 0.8321 & 0.3413 & 0.0 \\
\hline Standard error & 0.0009 & 0.0969 & 0.0273 & - \\
\hline Student's $t$ & 2.98 & 8.58 & 12.50 & - \\
\hline$P$ level & 0.0023 & 0.0000 & 0.0000 & - \\
\hline \multicolumn{5}{|c|}{ Floodplain meadow, Cherskii, East Siberia, Russia, 2003, day 214; $R^{2}=0.93 ; \mathrm{SE}=0.033 \mathrm{mg} \mathrm{CO} \cdot \mathrm{m}^{-2} \cdot \mathrm{s}^{-1}$} \\
\hline Estimate & 0.0006 & 0.2987 & 0.1038 & 0.9333 \\
\hline Standard error & 0.0001 & 0.0252 & 0.090 & 0.090 \\
\hline Student's $t$ & 5.31 & 11.85 & 11.58 & 10.38 \\
\hline$P$ level & 0.0000 & 0.0000 & 0.0000 & 0.0000 \\
\hline
\end{tabular}

Table 3. Parameters $\alpha, A_{\max }, r_{0}, k_{T}$, and $\theta$ from the modified nonrectangular hyperbolic light-temperature response function $F_{c}\left(Q, T_{\mathrm{s}}\right)=(1 / 2 \theta)\left(\alpha Q A_{\max } \sqrt{\left.\left(\alpha Q A_{\max }\right)^{2} 4 \alpha A_{\max } \theta Q\right)}-r_{0} e^{k_{T} T_{\mathrm{s}}}\right.$, for representative days at Doulun, Brookings, Howard, and Rondonia sites.

\begin{tabular}{|c|c|c|c|c|c|}
\hline \multirow[b]{2}{*}{ Statistical characteristics } & \multicolumn{5}{|c|}{ Parameters } \\
\hline & $\begin{array}{c}\text { Slope, } \\
\alpha \mathrm{mg} \mathrm{CO} 2 \cdot \mu \mathrm{mol}^{-1}\end{array}$ & $\begin{array}{l}\text { Plateau, } A_{\max } \mathrm{mg} \\
\mathrm{CO}_{2} \cdot \mathrm{m}^{-2} \cdot \mathrm{s}^{-1}\end{array}$ & $\begin{array}{l}\text { Respiration, } r_{0} \mathrm{mg} \\
\mathrm{CO}_{2} \cdot \mathrm{m}^{-2} \cdot \mathrm{s}^{-1}\end{array}$ & $\begin{array}{l}\text { Temperature coefficient, } \\
k_{\mathrm{T}},\left({ }^{\circ} \mathrm{C}\right)^{-1}\end{array}$ & $\begin{array}{c}\text { Convexity, } \\
\theta \text { dimensionless }\end{array}$ \\
\hline \multicolumn{6}{|c|}{ Steppe, Doulun, China, 2006, day 218; $R^{2}=0.98 ; \mathrm{SE}=0.037 \mathrm{mg} \mathrm{CO}{ }_{2} \cdot \mathrm{m}^{-2} \cdot \mathrm{s}^{-1}$} \\
\hline Estimate & 0.0009 & 0.5542 & 0.0377 & 0.0671 & 0.9644 \\
\hline Standard error & 0.00001 & 0.0241 & 0.0102 & 0.0116 & 0.0408 \\
\hline Student's $t$ & 9.08 & 22.98 & 3.68 & 5.78 & 23.64 \\
\hline$P$ level & 0.0000 & 0.0000 & 0.0003 & 0.0000 & 0.0000 \\
\hline \multicolumn{6}{|c|}{ Sown pasture, Brookings, SD, USA, 2005, day $190 ; R^{2}=0.99 ; \mathrm{SE}=0.032 \mathrm{mg} \mathrm{CO}{ }_{2} \cdot \mathrm{m}^{-2} \cdot \mathrm{s}^{-1}$} \\
\hline Estimate & 0.0014 & 1.0867 & 0.0631 & 0.0614 & 0.0000 \\
\hline Standard error & 0.0001 & 0.0498 & 0.0141 & 0.0094 & 0.0000 \\
\hline Student's $t$ & 13.87 & 21.81 & 4.48 & 6.53 & - \\
\hline$P$ level & 0.0000 & 0.0000 & 0.0000 & 0.0000 & - \\
\hline \multicolumn{6}{|c|}{ Wet-dry savanna, Howard, Australia, 2002, day $34 ; R^{2}=0.97 ; \mathrm{SE}=0.074 \mathrm{mg} \mathrm{CO} \cdot \mathrm{m}^{-2} \cdot \mathrm{s}^{-1}$} \\
\hline Estimate & 0.0017 & 1.147 & 0.0278 & 0.0690 & 0.8376 \\
\hline Standard error & 0.0003 & 0.1019 & 0.0167 & 0.0186 & 0.1529 \\
\hline Student's $t$ & 5.83 & 11.25 & 1.67 & 3.71 & 5.48 \\
\hline$P$ level & 0.0000 & 0.0000 & 0.0522 & 0.0004 & 0.0000 \\
\hline \multicolumn{6}{|c|}{ Tropical grassland, Rondonia, Brazil, 1999, day $270 ; R^{2}=0.97 ; \mathrm{SE}=0.052 \mathrm{mg} \mathrm{CO} 2 \cdot \mathrm{m}^{-2} \cdot \mathrm{s}^{-1}$} \\
\hline Estimate & 0.0008 & 0.8048 & 0.0339 & 0.0760 & 0.9902 \\
\hline Standard error & 0.0001 & 0.0721 & 0.0183 & 0.0217 & 0.0230 \\
\hline Student's $t$ & 9.38 & 11.16 & 1.85 & 3.50 & 43.04 \\
\hline$P$ level & 0.0000 & 0.0000 & 0.0408 & 0.0014 & 0.0000 \\
\hline
\end{tabular}



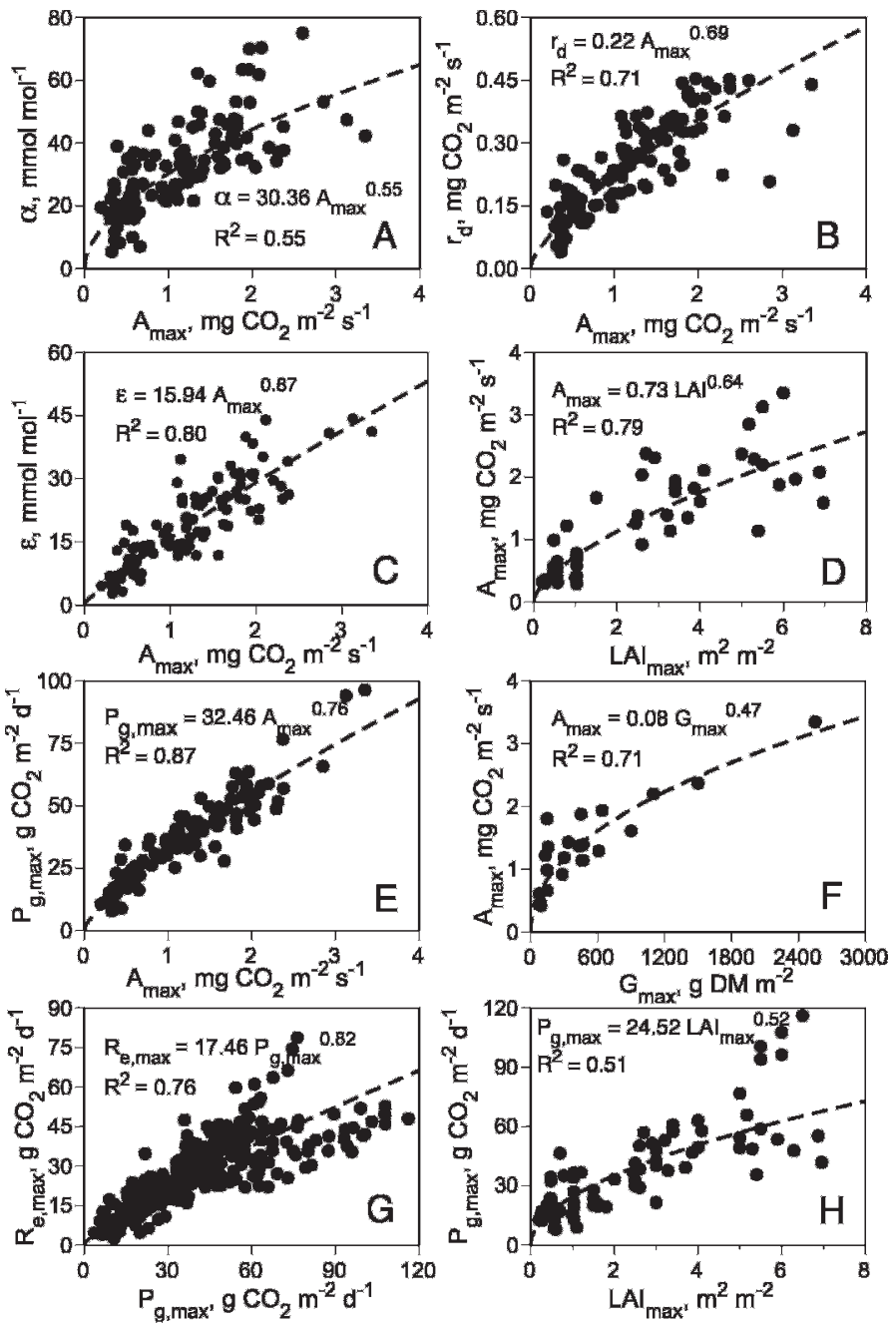

Figure 4. Scatter diagrams of maximum weekly values of lightresponse $\left(\alpha, A_{\max }, P_{\text {g,max }}, L_{\max }\right)$, metabolic $\left(r_{\mathrm{d}}, R_{\mathrm{e}, \max }\right)$, and efficiency $\left(\varepsilon, G_{\max }\right)$ parameters for the pooled data set including grasslands (extensively and intensively managed), shrublands and savannas, wetlands, and croplands: A, $\alpha$ vs. $A_{\max } ; \mathbf{B}, r_{\mathrm{d}}$ vs. $A_{\max } ; \mathbf{C}, \varepsilon$ vs. $A_{\max }$; D, $A_{\max }$ vs. $L_{\max } ; \mathrm{E}, P_{\mathrm{g}, \max }$ vs. $A_{\max } ; \mathrm{F}, A_{\max }$ vs. $G_{\max } ; \mathbf{G}, R_{\mathrm{e}, \max }$ vs. $P_{\mathrm{g}, \max } ;$ and $\mathbf{H}, P_{\mathrm{g}, \max }$ vs. $L_{\max }$. Dashed lines describe linear or power law equations characterizing patterns of covariation between parameters. See list of symbols for definitions.

The nonrectangular hyperbolic Equation 3 and its modification (Eq. 4) that takes into account the temperature dependence of daytime respiration were good numerical tools for fitting light responses of nonforest ecosystems for days when photosynthetically active radiation was the dominant factor governing ecosystem $\mathrm{CO}_{2}$ exchange. It is important to emphasize that the nonrectangular hyperbola provided a close fit to light-response data and provided consistent estimates of the light-response parameters for days when the $\left\{Q, F_{\mathrm{c}}\right\}$ plots showed no saturation with respect to $Q$ and were characterized by convexity parameter $\theta$ close to 1 (cf. Fig. 2A). The rectangular hyperbola, Mitscherlich's equation, and other approximations that lacked the convexity parameter fitted to data with such a pattern yielded highly biased estimates of the initial slope, plateau, and the intercept parameters.
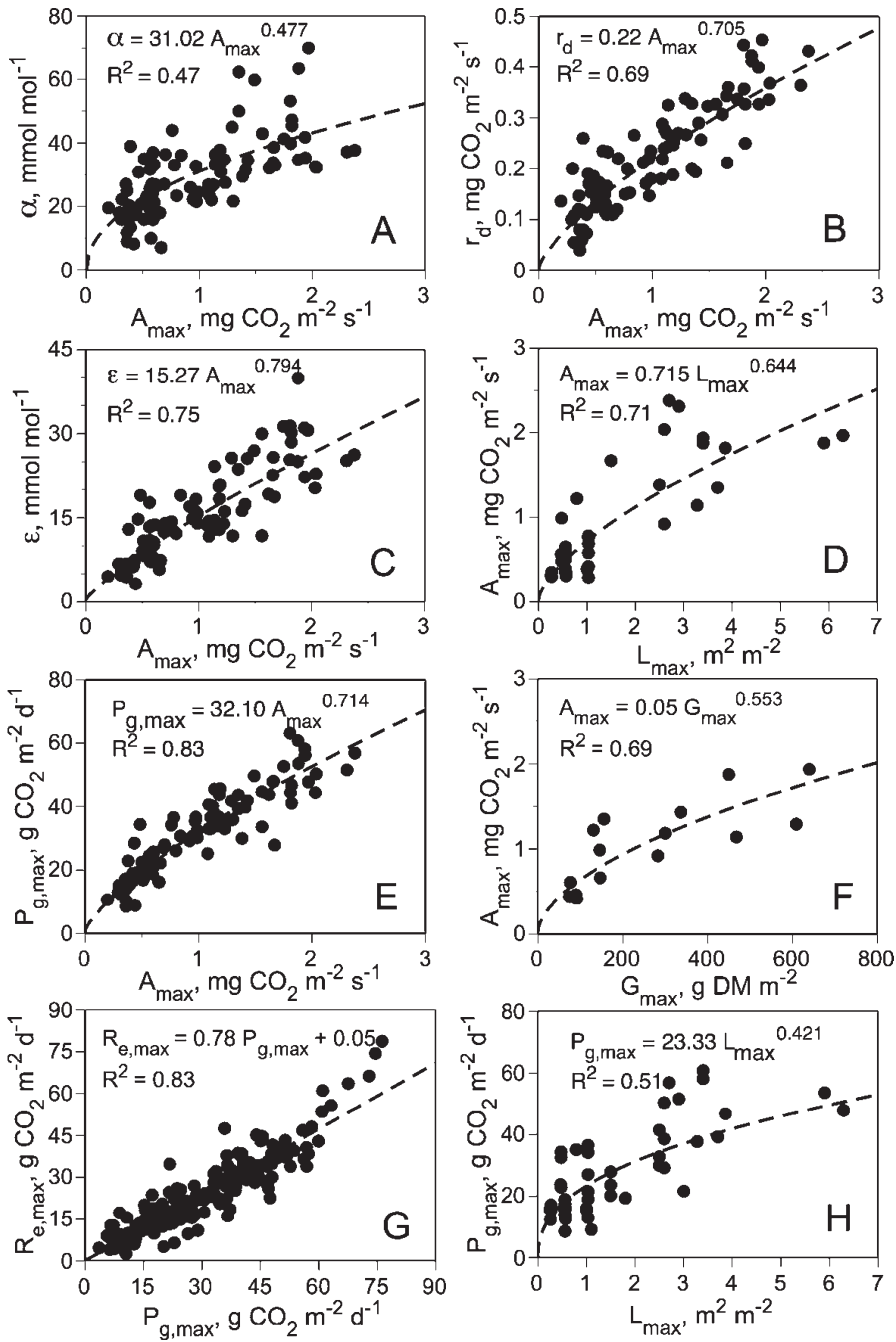

Figure 5. Scatter diagrams of maximum weekly values of lightresponse ( $\left.\alpha, A_{\max }, P_{g, \max }, L_{\max }\right)$, metabolic $\left(r_{\mathrm{d}}, R_{\mathrm{e}, \max }\right)$, and efficiency $\left(\varepsilon, G_{\max }\right)$ parameters for the extensively managed grasslands data subset: $\mathbf{A}, \alpha$ vs. $A_{\max } ; \mathbf{B}, r_{\mathrm{d}}$ vs. $A_{\max } ; \mathbf{C}, \varepsilon$ vs. $A_{\max } ; \mathbf{D}, A_{\max }$ vs. $L_{\max } ; \mathbf{E}$, $P_{\mathrm{g}, \text { max }}$ vs. $A_{\text {max }} ; \mathbf{F}, A_{\text {max }}$ vs. $G_{\text {max }} ; \mathbf{G}, R_{\mathrm{e}, \text { max }}$ vs. $P_{\mathrm{g}, \text { max }} ;$ and $\mathbf{H}, P_{\mathrm{g}, \text { max }}$ vs. $L_{\max }$. Dashed lines describe linear or power law equations characterizing patterns of co-variation between parameters. See list of symbols for definitions.

Estimates of apparent quantum efficiency, $\alpha$, in nonforest ecosystems cover a wide range of values (Fig. 4A) from $5 \mathrm{mmol} \cdot \mathrm{mol}^{-1}$ in the desert shrublands of Central Asia (Karrykul) to $75 \mathrm{mmol} \cdot \mathrm{mol}^{-1}$ in intensively managed grasslands of the North Atlantic (Cabauw, the Netherlands), with a mean value of $\alpha_{\text {nonfor }}=33.3 \mathrm{mmol} \cdot \mathrm{mol}^{-1}$ and a standard deviation of $s_{\text {nonfor }}=14.2 \mathrm{mmol} \cdot \mathrm{mol}^{-1}$. The lower $10 \%$ quantile of the $\alpha$ values in the sample $\left(5-17 \mathrm{mmol} \cdot \mathrm{mol}^{-1}\right)$ included extensively managed arid and semiarid grasslands and shrublands (Karrykul, Cottonwood, Karnap, Audubon, Lethbridge, Kherlenbayan-Ulaan, Tojal, and Fort Peck), while the upper $10 \%$ quantile $\left(50-75 \mathrm{mmol} \cdot \mathrm{mol}^{-1}\right)$ encompassed intensively managed grasslands (Cabauw, Carlow, Neustift, Easter Bush, Oensingen, Lille Valby, Grillenburg, Haller), extensively managed grasslands under favorable weather conditions (Laqueuille-extensive, Rigi-Seebodenalp, Jornada), 
A. Cherskii, floodplain meadow, 2003
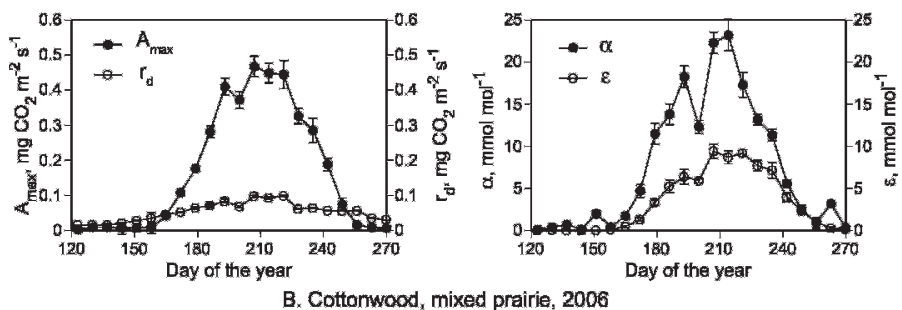

B. Cottonwood, mixed prairie, 2006
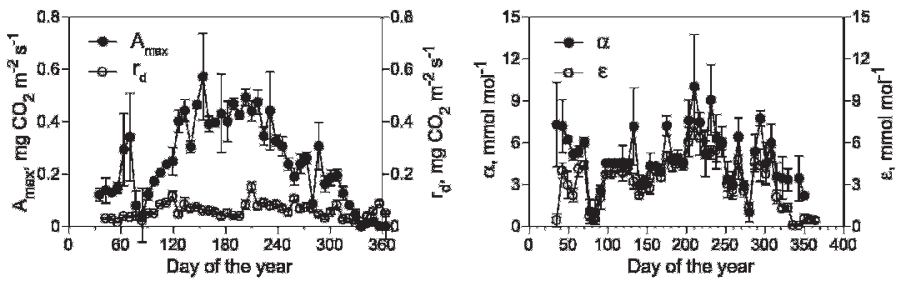

C. Gudmundsen, mixed prairie, 2006

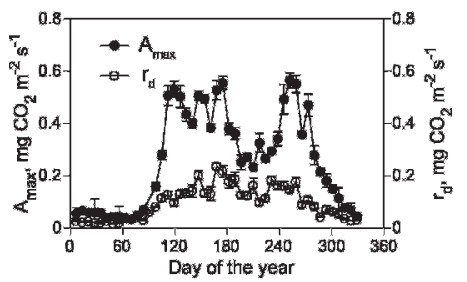

D. Fort Reno, tallgrass prairie, 2005
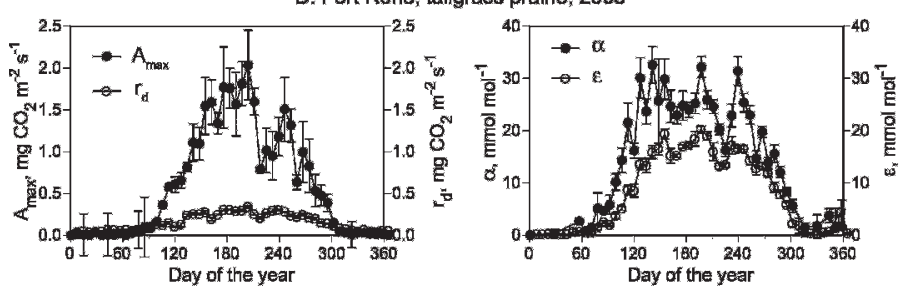

Ex Howard, wet-dry savanna, 2002

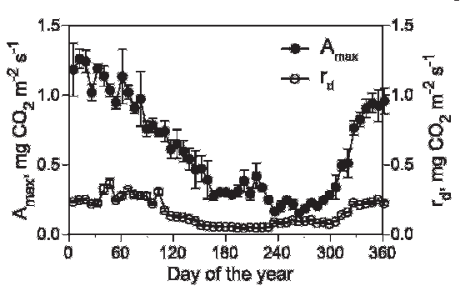

F. Rondonia, tropical grassland, 1999
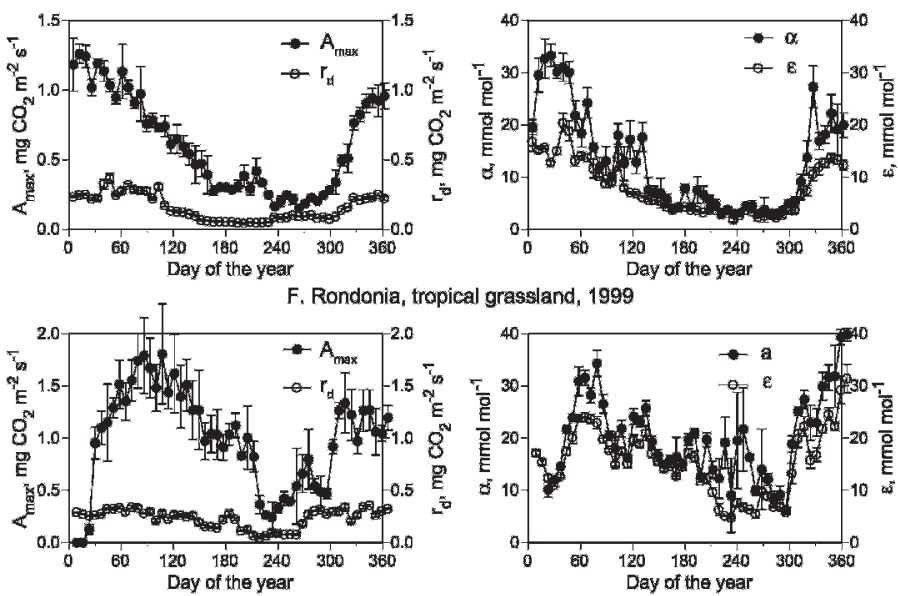

G. Lonzee, sugar beet, 2004
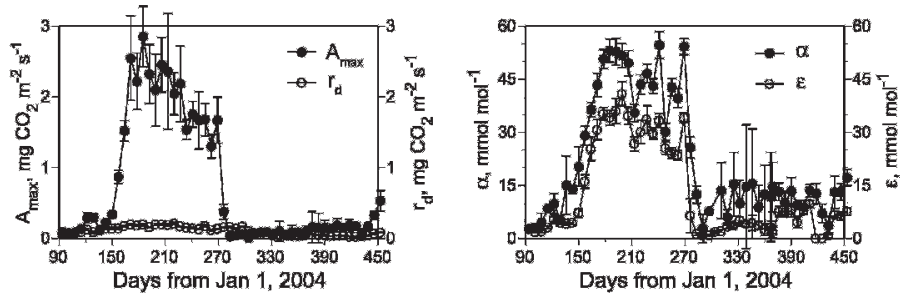

H. Bondville, corn, 1999
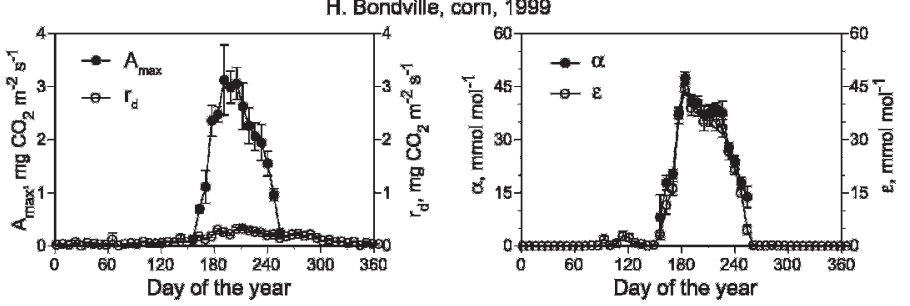

Figure 6. Seasonal dynamics of light-response parameters: maximum photosynthesis, $A_{\max }$, daytime ecosystem respiration, $r_{\mathrm{d}}$, quantum yield, $\alpha$, and gross ecological light-use efficiency, $\varepsilon$, in selected nonforest ecosystems: A, floodplain meadow, Cherskii, 2003; B, mixed prairie, Cottonwood, 2006; C, mixed prairie, Gudmundsen Ranch, 2006; D, tallgrass prairie, Fort Reno, 2005; E, wet-dry savanna, Howard, 2002; F, tropical grassland, Rondonia, 1999; G, sugar beet, Lonzee, 2004; H, maize crop, Bondville, 1999.

and intensive agricultural crops (Lonzee). Interestingly, most productive crop sites, characterized by the highest $A_{\max }$ and $P_{\mathrm{g}, \max }$ values, were not included in the upper $10 \%$ quantum yield quantile, although they often were parceled into the upper $20 \%$ quantum yield quantile.

Besides examining scatter plots for the pooled data set, understanding relationships among parameters within a particular ecosystem is of interest. Presently, only a subset of extensively managed grasslands had scatter diagrams that exhibited pronounced patterns of covariation (Fig. 5).

In evaluating estimates of quantum yield, our maximum estimate of $75 \mathrm{mmol} \cdot \mathrm{mol}^{-1}$ was only two-thirds of the theoretical maximum of quantum efficiency of gross photosynthesis estimated by Good and Bell $(1980 ; 110 \mathrm{mmol}$. $\left.\mathrm{mol}^{-1}\right)$. We compared our nonforest estimates with those reviewed by Ruimy et al. (1995) from which we estimated a mean $\bar{\alpha}_{\text {orest }}=37 \mathrm{mmol} \cdot \mathrm{mol}^{-1}$ with a standard deviation of $s_{\text {forest }}=17 \mathrm{mmol} \cdot \mathrm{mol}^{-1}$, excluding data in Ruimy et al. 1995 with $\alpha$ values greater than the theoretical maximum of quantum efficiency after Good and Bell (1980). We found that quantum efficiency of non-forest ecosystems was not statisti- cally different from forests. In fact, $\alpha_{\text {max,nonforest }}$ estimated for intensively managed Cabauw grassland in the Netherlands $\left(75 \mathrm{mmol} \cdot \mathrm{mol}^{-1}\right.$ ) was numerically higher, but statistically not significantly different from the maximum quantum efficiency determined for the chestnut coppice near Paris, France $\left(\alpha_{\text {max }, \text { forest }}=73 \mathrm{mmol} \cdot \mathrm{mol}^{-1}\right.$; Mordacq et al. 1991).

The values of maximum average weekly gross photosynthesis, $A_{\max }$, for nonforest sites of the world (Fig. 4A) ranged from $0.2 \mathrm{mg} \mathrm{CO}_{2} \cdot \mathrm{m}^{-2} \cdot \mathrm{s}^{-1}$ (Fort Peck mixed prairie during a drought year) to $3.4 \mathrm{mg} \mathrm{CO} \mathrm{CO}_{2} \cdot \mathrm{m}^{-2} \cdot \mathrm{s}^{-1}$ (Mead, irrigated continuous maize). The lower $10 \%$ quantile $(0.2-0.36 \mathrm{mg}$ $\mathrm{CO}_{2} \cdot \mathrm{m}^{-2} \cdot \mathrm{s}^{-1}$ ) included Fort Peck, Dubois, Miles City, Kherlenbayan-Ulaan, Xilinhot, Karrykul, Kubuqi, Burns, and Karnap, and the upper $10 \%$ quantile (2-3.4 mg $\mathrm{CO}_{2} \cdot \mathrm{m}^{-2} \cdot \mathrm{s}^{-1}$ ) included intensive crops (Mead, Bondville, Lonzee, Ames), intensively managed grasslands (Cabauw, Carlow, Lille Valby), and tallgrass prairies (Shidler, Fort Reno). The mean photosynthetic capacity of nonforest ecosystems $\left(1.2 \mathrm{mg} \mathrm{CO} 2 \cdot \mathrm{m}^{-2} \cdot \mathrm{s}^{-1}, \mathrm{SD}=0.68 \mathrm{mg} \mathrm{CO} \cdot \mathrm{m}^{-2} \cdot \mathrm{s}^{-1}\right)$ lies at the upper end of the mean $A_{\max }$ range for different forest types from eddy covariance estimates $\left(0.66 \mathrm{mg} \mathrm{CO} 2 \cdot \mathrm{m}^{-2} \cdot \mathrm{s}^{-1}\right.$ 
A. Cherskii, floodplain meadow, 2003

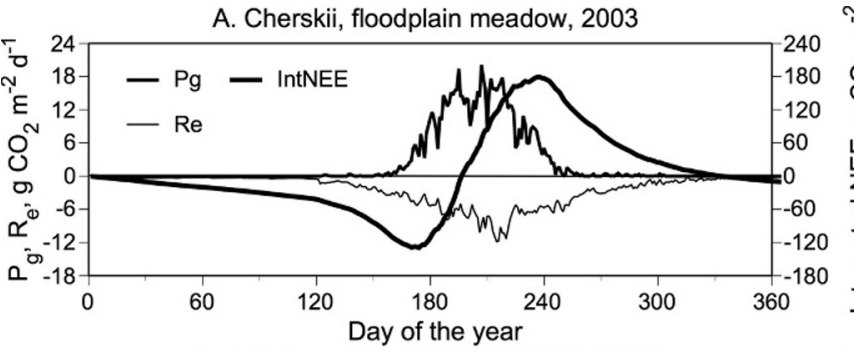

B. Jokioinen, sown grassland, 2001-2002

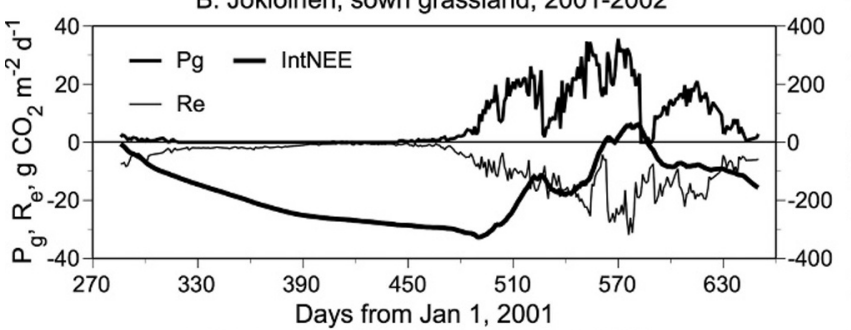

C. Grillenburg, temperate grassland, 2005

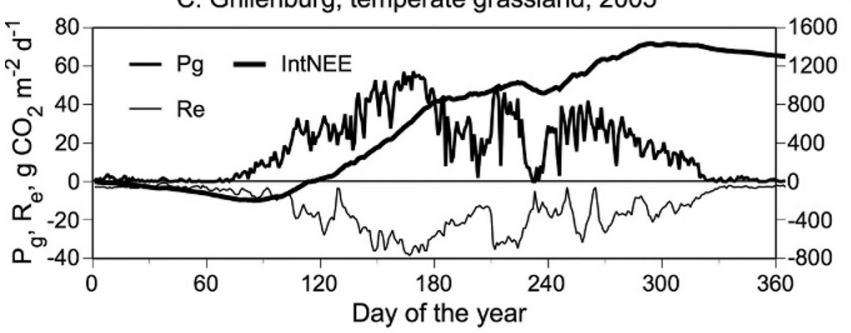

D. Audubon, desert grassland, 2004

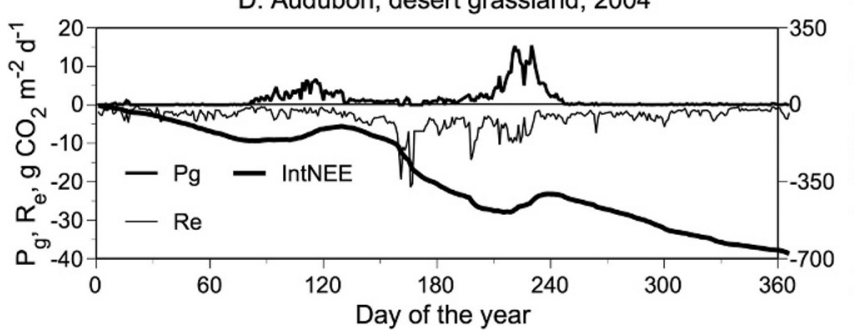

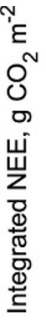

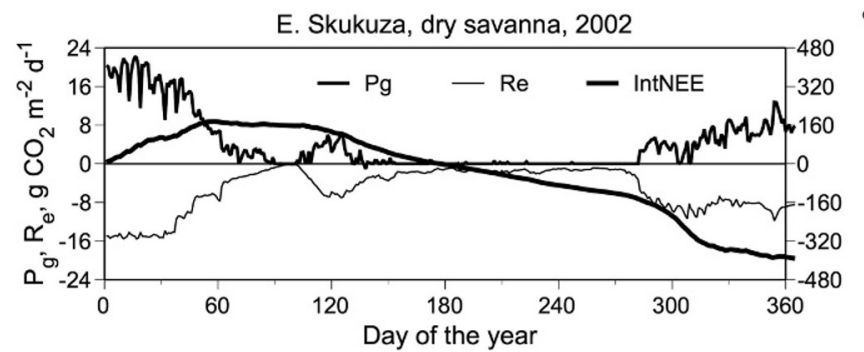

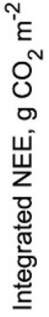
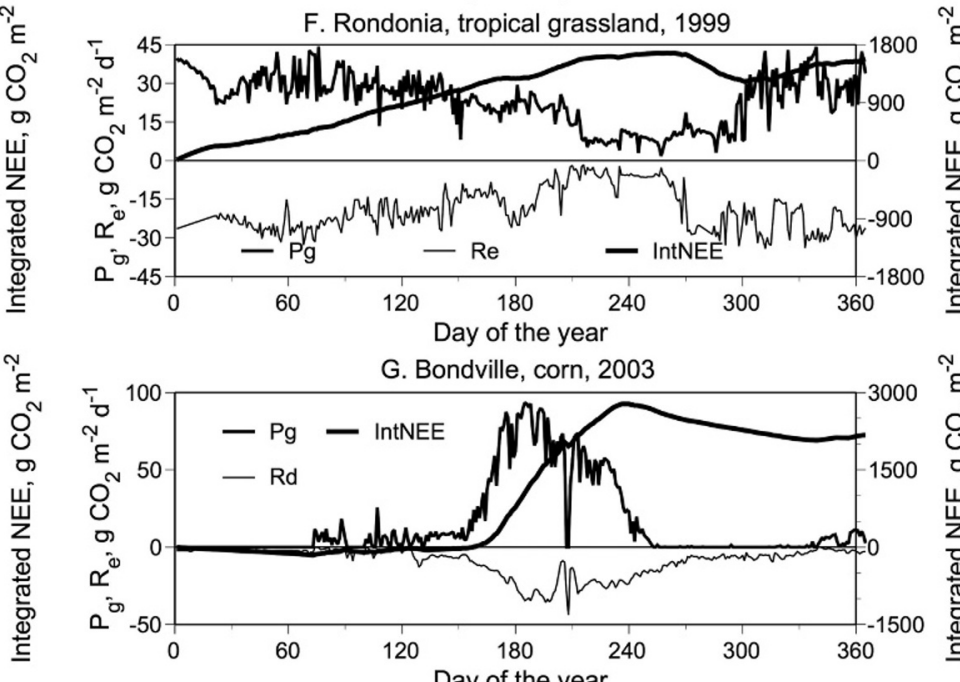

G. Bondville, corn, 2003
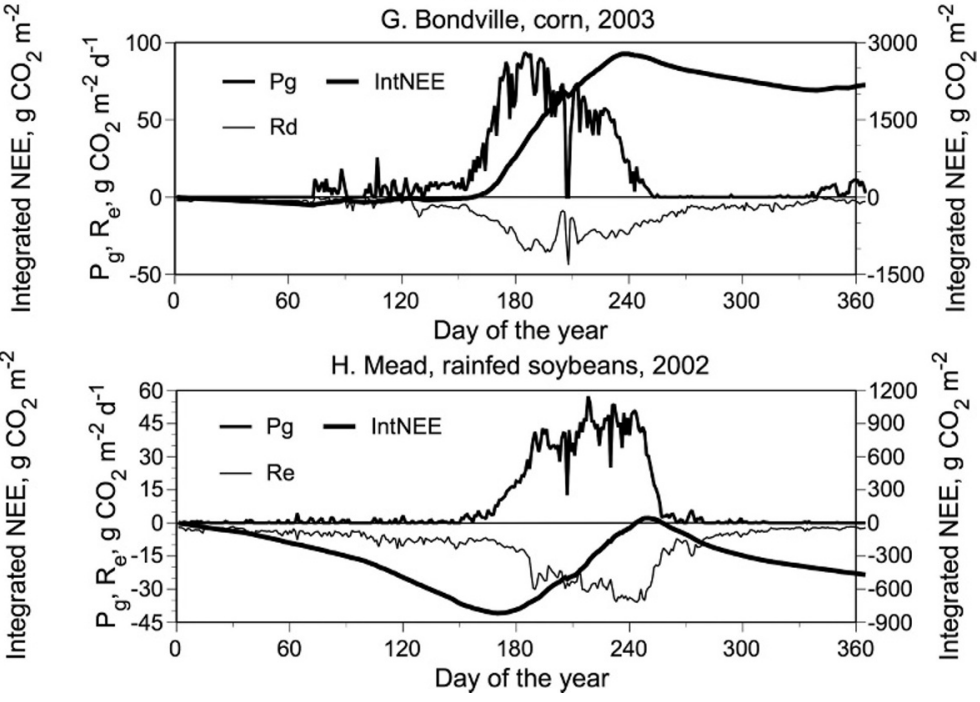

Figure 7. Seasonal dynamics and annual budgets of gross primary productivity, $P_{\mathrm{g}}(t)$, total ecosystem respiration, $R_{\mathrm{e}}(t)$, and integrated net ecosystem $\mathrm{CO}_{2}$ exchange, IntNEE $(t)$, for selected nonforest sites and years: A, floodplain meadow, Cherskii, 2003; B, sown northern temperate grassland, Jokioinen, 2001-2002; C, temperate grassland, Grillenburg, 2005; D, desert grassland, Audubon Ranch, 2004; E, dry savanna, Skukuza, 2002; F, tropical grassland, Rondonia, 1999; G, maize crop, Bondville, 2003; H, soybean crop, Mead, 2002.

to $1.3 \mathrm{mg} \mathrm{CO} \mathrm{CO}_{2} \cdot \mathrm{m}^{-2} \cdot \mathrm{s}^{-1}$, mean $=0.97 \mathrm{mg} \mathrm{CO} \mathrm{CO}_{2} \cdot \mathrm{m}^{-2} \cdot \mathrm{s}^{-1}$; Falge et al. 2002; Funk and Lerdau 2004). At the same time, the highest $A_{\max }$ value for nonforest ecosystems found in intensive maize cultures of the midwestern United States $(3.4 \mathrm{mg}$ $\mathrm{CO}_{2} \cdot \mathrm{m}^{-2} \cdot \mathrm{s}^{-1}$ ) were substantially higher than $A_{\max }=2.64 \mathrm{mg}$ $\mathrm{CO}_{2} \cdot \mathrm{m}^{-2} \cdot \mathrm{s}^{-1}$ estimated from data by Jarvis (1994) for a Sitka spruce culture in Scotland.

The values of daytime ecosystem respiration rate $\left(r_{\mathrm{d}}\right)$ in all ecosystems were substantially lower than corresponding $A_{\max }$ values (cf. Fig. 6, left), but varied substantially among ecosystem types (Fig. 4B) with maximum weekly average $r_{\mathrm{d}}$ ranging an order of magnitude from $0.04 \mathrm{mg} \mathrm{CO} 2 \cdot \mathrm{m}^{-2} \cdot \mathrm{s}^{-1}$ (Burns, drought year) to $0.45 \mathrm{mg} \mathrm{CO}_{2} \cdot \mathrm{m}^{-2} \cdot \mathrm{s}^{-1}$ (Ames, Neustift, warm and wet years). The lower $10 \%$ quantile of maximum weekly $r_{\mathrm{d}}$ values included arid and semiarid grasslands and shrublands (Burns, Karnap, KherlenbayanUlaan, Karrykul, Cottonwood, Burns, Dubois, Kubuqi) and tundra (Barrow). The upper $10 \%$ quantile of $r_{\mathrm{d}}$ distribution was represented by intensively managed grasslands (Neustift,
Cabauw, Carlow, Oensingen, Lille Valby, Easter Bush, Haller), intensive crops (Ames, Mead), tallgrass prairies (Shidler, Rannels Ranch), and a semidesert grassland in a year with exceptionally high precipitation (Jornada).

The weekly maxima of the coefficient of gross ecological light-use efficiency, $\varepsilon$, observed in this study ranged from 3 to $59 \mathrm{mmol} \cdot \mathrm{mol}^{-1}$ (mean 22, standard deviation $12.4 \mathrm{mmol}$. $\mathrm{mol}^{-1}$ ) and were lower than the weekly maxima of apparent quantum yield, $\alpha$ (Fig. 6, right). For some ecosystems, particularly for agricultural $\mathrm{C}_{4}$ crops and tropical grasslands dominated by $\mathrm{C}_{4}$ species, $\varepsilon$ values were not considerably lower than $\alpha$ (e.g., see Figs. $6 \mathrm{E}, 6 \mathrm{~F}$, and $6 \mathrm{H}$, right). This is a direct result of relatively high values of the convexity coefficient of the light curves of $\mathrm{C}_{4}$ species; for the case where $\theta=1$, the values of $\alpha$ and $\varepsilon$ become equal, provided input radiation levels remain within the range of linear light response.

In $\mathrm{C}_{3}$ communities characterized by low convexity values $(\theta=0$ in the extreme case of rectangular hyperbolic light response), ecological light-use efficiency remains substantially 
Table 4. Statistical characteristics of annual gross primary production (GPP), total ecosystem respiration (RE), and net ecosystem exchange (NEE) for major groups within nonforest terrestrial ecosystems.

\begin{tabular}{|c|c|c|c|c|c|}
\hline \multirow[b]{2}{*}{$\begin{array}{c}\text { Statistical } \\
\text { characteristics }\end{array}$} & \multicolumn{5}{|c|}{ Ecosystem group } \\
\hline & $\begin{array}{c}\text { Grasslands extensively } \\
\text { managed }\end{array}$ & $\begin{array}{c}\text { Grasslands intensively } \\
\text { managed }\end{array}$ & Shrublands and savanna & Wetlands & Croplands \\
\hline \multicolumn{6}{|c|}{$\mathrm{GPP}\left(\mathrm{g} \mathrm{CO}_{2} \cdot \mathrm{m}^{-2} \cdot \mathrm{yr}^{-1}\right)$} \\
\hline No. of site-years & 173 & 40 & 28 & 48 & 66 \\
\hline Mean & 565 & 6014 & 2949 & 2328 & 4521 \\
\hline SD & 1698 & 1133 & 1950 & 1836 & 1365 \\
\hline Min. & 95 & 3141 & 645 & 749 & 1376 \\
\hline Max. & 8600 & 7720 & 6836 & 5643 & 6774 \\
\hline \multicolumn{6}{|c|}{$\operatorname{RE}\left(\mathrm{g} \mathrm{CO}_{2} \cdot \mathrm{m}^{-2} \cdot \mathrm{yr}^{-1}\right)$} \\
\hline No. of site-years & 163 & 40 & 27 & 18 & 66 \\
\hline Mean & 2370 & 5296 & 2537 & 1824 & 3588 \\
\hline SD & 1469 & 1040 & 1396 & 1373 & 909 \\
\hline Min. & 112 & 3186 & 756 & 665 & 1052 \\
\hline Max. & 7021 & 7880 & 5094 & 4751 & 5905 \\
\hline \multicolumn{6}{|c|}{ NEE $\left(\mathrm{g} \mathrm{CO}_{2} \cdot \mathrm{m}^{-2} \cdot \mathrm{yr}^{-1}\right)$} \\
\hline No. of site-years & 163 & 40 & 27 & 18 & 66 \\
\hline Mean & 255 & 700 & 493 & 504 & 933 \\
\hline SD & 521 & 717 & 740 & 719 & 814 \\
\hline Min. & -1342 & -961 & -585 & -40 & -770 \\
\hline Max. & 1762 & 2394 & 2254 & 2226 & 2382 \\
\hline
\end{tabular}

lower than quantum yield (Fig. 6A, right). The lower $10 \%$ quantile of light-use efficiency values $\varepsilon\left(2.6-6.4 \mathrm{mmol} \cdot \mathrm{mol}^{-1}\right)$ includes deserts, desert and dry-steppe grasslands, shortgrass and sagebrush steppes, mixed prairies, California grasslands and chaparral, and tundra (Karrykul, Karnap, Audubon Ranch, Kendall, Xilinhot, Central Plains Experimental Range, Fort Peck, Cottonwood, Burns, Kubuqi, Kherlenbayan-Ulaan, Sky Oaks, Barrow, Atqasuk, Ivotuk). The upper 10\% quantile of the $\varepsilon$ values $\left(40-59 \mathrm{mmol} \cdot \mathrm{mol}^{-1}\right)$ mostly included high-yield crops (Risbyholm, Langerak, Molenweg, Mead, Bondville, Oensingen, Gebesee, Lonzee, Batavia) as well as highly productive managed grasslands (Carlow, Lille Valby, Oensingen, Neustift).

To compare $\varepsilon_{\max }$ estimates for forest and nonforest ecosystems, we calculated average weekly values of light-use efficiency for the 12 most productive forest ecosystems in the FLUXNET La Thuile database. These $12 \varepsilon_{\max }$ values ranged between 29.1 and $47.7 \mathrm{mmol} \cdot \mathrm{mol}^{-1}$, with the highest value found in the 2001 data set for the Duke loblolly pine forest (North Carolina), which is less than $\varepsilon_{\max }=59 \mathrm{mmol} \cdot \mathrm{mol}^{-1}$ for a high-yield crop (also, see Table 5 for $P_{\mathrm{g}, \max }$ comparison of forests and nonforest ecosystems). Thus, the light-use efficiency data agreed with observations presented earlier in this section that the values of maximum apparent quantum yield in nonforest ecosystems (particularly, intensively managed grasslands) were comparable and sometimes higher than those for forest ecosystems.

\section{Parameter Interrelations}

As expected, numerical values of light-response parameters among various ecosystems did not vary independently of each other, but demonstrated patterns of correlation (Figs. 4 and 5). Our results for this extensive data set agreed with those of earlier studies with smaller subsets of flux-tower data, suggesting that the plateau parameter of gross photosynthesis, $A_{\max }$, was a good predictor for other light-response parameters, including quantum yield, $\alpha$, ecosystem respiration rate, $r_{\mathrm{d}}$, and light-use efficiency, $\varepsilon$ (Gilmanov et al. 2007; Owen et al. 2007). Baldocchi and Xu (2005) found that $A_{\max }$ was a good predictor for another photosynthetic parameter, the maximum rate of carboxylation $\left(V_{c, \text { max }}\right)$. In previous studies, mostly linear relationships were observed between $A_{\max }$ and other parameters; however, the wider range of parameter variations in our data set revealed a number of distinct nonlinearities. For example, a power-law relationship $\alpha=30.36\left(A_{\max }\right)^{0.55}$ with $R^{2}$ value of 0.55 was obtained for the relationship between apparent quantum yield and maximum photosynthesis (Fig. 4A). The better fit of the nonlinear (with power exponent $<1)$ description of the $\alpha\left(A_{\max }\right)$ relationship compared to the simple linear model was demonstrated by the fact that the nonlinear model exhibited a decrease in $\alpha$ with decreasing $A_{\max }$ as the latter approached 0 , while the linear model predicted an unrealistic $\alpha_{0}$ value of $\sim 15 \mathrm{mmol} \cdot \mathrm{mol}^{-1}$ even when $A_{\max }$ approached 0 .

Daytime ecosystem respiration $\left(r_{\mathrm{d}}\right)$ also demonstrated a power law relationship with $A_{\max }$ described as $r_{\mathrm{d}}=0.22\left(A_{\max }\right)^{0.71}$ with $R^{2}=0.69$ (Fig. 5B). In this case, the linear model also provided a reasonable fit to the data $\left(R^{2}=0.67\right)$, though its applicability to the region of low $A_{\max }$ values was limited by an unrealistically large intercept of $r_{\mathrm{d}}=0.09 \mathrm{mg} \mathrm{CO} \cdot \mathrm{m}^{-2} \cdot \mathrm{s}^{-1}$ as $A_{\max }$ approached 0. From the patterns of data points in Figures $5 \mathrm{C}$ and $5 \mathrm{D}$, the relationships between ecological lightuse efficiency, maximum daily gross photosynthesis, and $L_{\max }$ may be approximated by both the linear and the power-law equations, though the latter provided better fit in the lower range of $A_{\max }$ and $L_{\max }$. 
Maximum leaf area $\left(L_{\max }\right)$ and/or maximum aboveground green biomass $\left(G_{\max }\right)$ was not available for all flux sites. With the limited data available (Figs. $5 \mathrm{~F}$ and $5 \mathrm{H}$ ), we established nonlinear power law (with exponent coefficient $<1$ ) dependence of maximum photosynthesis parameters $\left(A_{\max }, P_{\mathrm{g}, \max }\right)$ and the standard morphometric characteristics such as maximum aboveground biomass, $G_{\max }$, and maximum leaf area index, $L_{\max }$ (Figs. 5F and 5H).

\section{Seasonal Patterns of Parameter Dynamics}

The light-response parameters evaluated from flux-tower measurement data sets represented not only physiological characteristics (which also change through time with phenology and environmental conditions) but also ecosystem-scale attributes such as aboveground biomass, leaf-area index, and others. As a result, such parameters exhibited pronounced variation in magnitude during the year. Seasonal changes of these parameters, though specific for particular sites and years, exhibited general patterns revealed in time plots of parameter values aggregated at the weekly time step (Fig. 6). Pronounced seasonal dynamics of light-response parameters for cold and temperate environments were closely related to radiation and temperature (Figs. 6A and 6D); however, under arid conditions they were closely associated with fluctuations in precipitation (Figs. 6E and 6F). This climatically driven unimodal pattern of seasonal parameter change was particularly pronounced in species-poor ecosystems or monocultures with a relatively narrow production period, be that a floodplain meadow in the tundra zone (Fig. 6A) or agricultural crops (Figs. 6G and 6H). In ecosystems with a higher species diversity and broader production period (up to year-round production under tropical conditions), the general seasonal pattern of parameter dynamics was compounded by additional fluctuations that reflected different reactions of various species groups (e.g., cool and warm-season grasses) to weather variability and management regime (grazing, mowing) during various parts of the year (Figs. 6B-6D). These data may help to explain difficulties experienced by those attempting to simulate year-round dynamics of gross primary productivity and light-response parameters by modification of the hypothetical maximum parameter value by factors-multipliers that describe effects of various drivers such as radiation, temperature, moisture, etc. (cf. Monteith 1972; Ciais et al. 2001).

Seasonal Dynamics and Annual Budgets of GPP, RE, and NEE Depending on a number of external (e.g., radiation, temperature, precipitation) and internal (e.g., leaf area, phenological state, water and nutrient supply) ecological factors, the functions of gross primary productivity $\left(P_{\mathrm{g}}[t]\right)$, and total ecosystem respiration $\left(R_{\mathrm{e}}[t]\right)$ demonstrated pronounced temporal dynamics during the year. This was exemplified by measurement-based estimates of $P_{\mathrm{g}}(t)$ and $R_{\mathrm{e}}(t)$ (Fig. 7). The curve of integrated net ecosystem exchange (IntNEE[t]) was much smoother, and its value at the end of the year (NEE) provided a summary of ecosystem $\mathrm{CO}_{2}$ budget.

Data from the analyzed data sets demonstrated a large variety of seasonal patterns of productivity and respiration dynamics, with some of the typical curves illustrated in Figure 7. Three major seasonal patterns of the cumulative
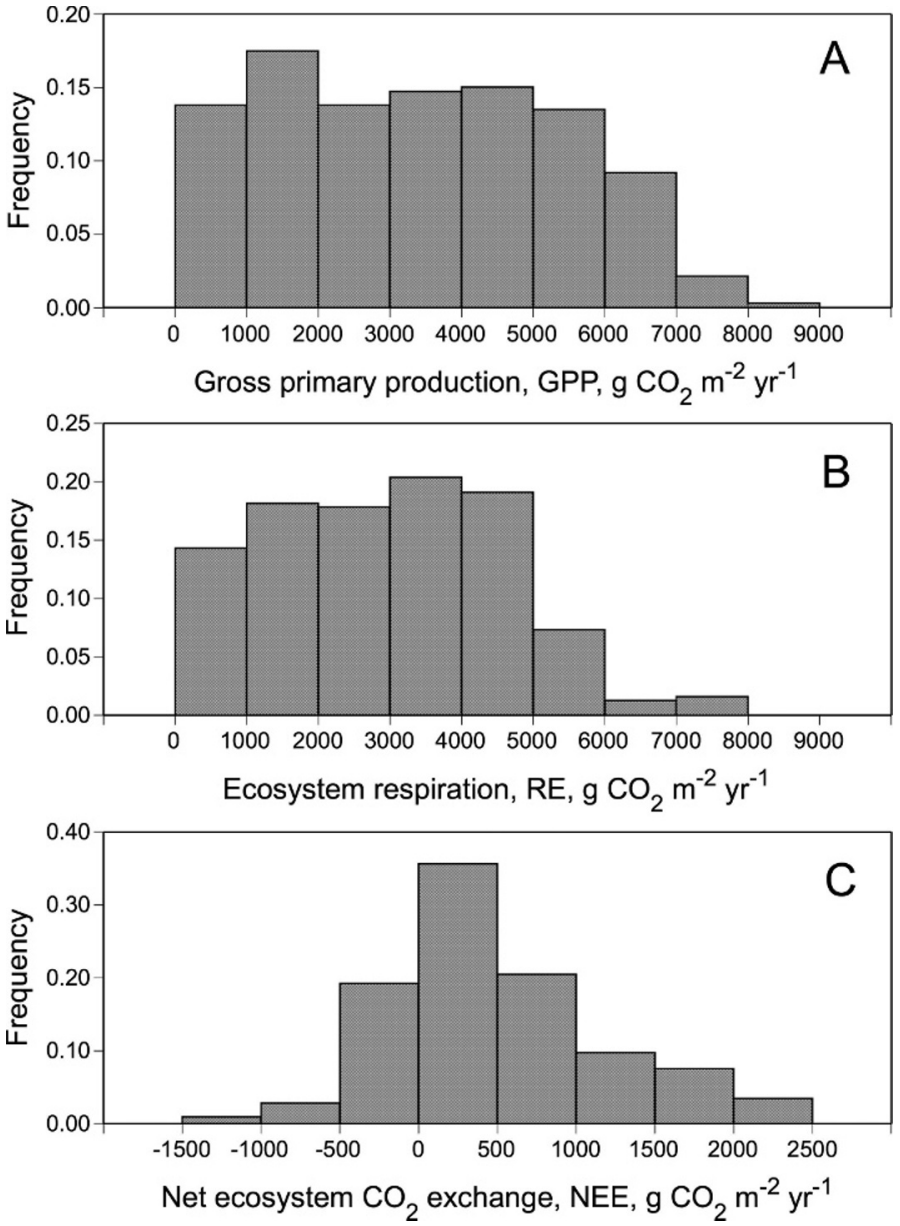

Figure 8. Frequency distributions of $\mathbf{A}$, gross primary production (GPP); B, ecosystem respiration (RE); and C, net ecosystem $\mathrm{CO}_{2}$ exchange (NEE) estimates in the pooled set site-years from nonforest flux-tower sites.

NEE curve were evident: 1) equilibrium (S-shaped), 2) permanent accumulation, and 3) permanent release of carbon. The equilibrium pattern (1) characterizing nonharvested ecosystems with marked seasonality of primary productivity was exemplified by data from a floodplain tundra meadow at Cherskii in the Far northeast of Russia (Fig. 7A). With the period of decomposition activity (May-September) completely encompassing the production period (June-August) and with maximum decomposition lagging behind maximum production, the curve of cumulative NEE assumed a characteristic Sshaped form with the net annual ecosystem $\mathrm{CO}_{2}$ exchange near zero. The accumulative pattern was described by the more or less monotonous accumulation of net ecosystem production in ecosystems with a period of marked domination of production compared to decomposition processes observed in both grassland (Fig. 7F) and cropland ecosystems (Fig. 7G). The third pattern of nearly permanent domination of respiratory efflux over assimilatory uptake resulting in significant net loss of carbon dioxide from the ecosystem at the end of the year was exemplified by measurements at the Audubon (AZ) desert grassland on a high carbonate soil (Fig. 7D; cf. Emmerich 2003). These three major patterns were accompanied by a variety of intermediate variants with local maxima and minima 
Table 5. Maximum values of daytime gross primary productivity, $P_{\mathrm{g}, \mathrm{max}}$, and annual net primary production, GPP, estimated for nonforest and forest flux-tower sites.

\begin{tabular}{|c|c|c|c|c|c|}
\hline Site & Year & $\begin{array}{c}P_{\mathrm{g}, \max } \\
\mathrm{g} \mathrm{CO}_{2} \cdot \mathrm{m}^{-2} \cdot \mathrm{d}^{-1}\end{array}$ & Site & Year & $\begin{array}{c}\mathrm{GPP} \\
\mathrm{g} \mathrm{CO}_{2} \cdot \mathrm{m}^{-2} \cdot \mathrm{yr}^{-1}\end{array}$ \\
\hline \multicolumn{6}{|l|}{ Grasslands extensively managed } \\
\hline Jornada, NM, USA & 2000 & 63.1 & Rondonia, Brazil & 1999 & 8600 \\
\hline Rannels Ranch, KS, USA & 1998 & 60.8 & Goodwin Creek, MS, USA & 2004 & 6391 \\
\hline Batavia Prairie Site, IL, USA & 2006 & 59.9 & Grillenburg, Germany & 2005 & 6299 \\
\hline Grillenburg, Germany & 2005 & 57.34 & Duke grassland, NC, USA & 2003 & 6039 \\
\hline Monte Bondone, Italy & 2006 & 56.9 & Laqueuille, France, extensive & 2006 & 5943 \\
\hline Shidler, OK, USA & 1999 & 56.9 & Neal Smith, IA, USA & 2005 & 5756 \\
\hline Temple, TX, USA & 1999 & 56.2 & Batavia Prairie Site, IL, USA & 2006 & 5435 \\
\hline Oensingen, Switzerland & 2003 & 53.6 & Oensingen, Switzerland & 2003 & 5326 \\
\hline Neal Smith, IA, USA & 2005 & 52.7 & Laqueuille, France, extensive & 2004 & 5322 \\
\hline Laqueuille, France, extensive & 2004 & 51.7 & Rigi-Seebodenalp, Switzerland & 2003 & 5320 \\
\hline Goodwin Creek, MS, USA & 2003 & 51.4 & Shidler, OK, USA & 1997 & 5208 \\
\hline Amplero, Italy & 2004 & 48.1 & Monte Bondone, Italy & 2006 & 5168 \\
\hline \multicolumn{6}{|l|}{ Grasslands intensively managed } \\
\hline Cabauw-extension, The Netherlands & 2005 & 76.3 & Oensingen, Switzerland & 2004 & 7720 \\
\hline Neustift, Austria & 2004 & 76.2 & Neustift, Austria & 2006 & 7415 \\
\hline Easter Bush, United Kingdom & 2003 & 63.6 & Dripsey-grass, Ireland & 2004 & 7388 \\
\hline Oensingen, Switzerland & 2004 & 63.5 & Haastrecht, The Netherlands & 2003 & 7267 \\
\hline Lille Valby, Denmark & 2006 & 63.4 & Lille Valby, Denmark & 2004 & 6873 \\
\hline Haastrect, Netherlands & 2003 & 63.1 & Laqueuille, France, intensive & 2004 & 6838 \\
\hline Laqueuille, France, intensive & 2006 & 59.0 & Carlow-grassland, Ireland & 2003 & 6807 \\
\hline Carlow-grassland, Ireland & 2003 & 57.9 & Easter Bush, United Kingdom & 2003 & 6793 \\
\hline Haarweg, The Netherlands & 2002 & 57.5 & Cabauw-extension, The Netherlands & 2005 & 6785 \\
\hline Dripsey-grass, Ireland & 2003 & 54.7 & Haarweg, The Netherlands & 2002 & 5915 \\
\hline Lacombe, Alberta, Canada & 2003 & 53 & Hegyhátsál, Hungary & 1999 & 5867 \\
\hline Haller, State College, PA, USA & 2004 & 52.2 & Cabauw, The Netherlands & 2004 & 5837 \\
\hline \multicolumn{6}{|l|}{ Shrubs and savannas } \\
\hline Howard Springs, Australia & 2005 & 54.2 & Sao Paulo cerrado, Brazil & 2002 & 6836 \\
\hline Sao Paulo cerrado, Brazil & 2002 & 42.7 & Howard Springs, Australia & 2002 & 5874 \\
\hline Tonzi Ranch, California & 2005 & 38.6 & Skukuza, South Africa & 2001 & 3947 \\
\hline Skukuza, South Africa & 2001 & 34.6 & Tonzi Ranch, CA, USA & 2005 & 3837 \\
\hline Tonzi Ranch, California & 2003 & 34.1 & Sky Oaks Old stand, CA, USA & 1997 & 2682 \\
\hline Sky Oaks Young stand, CA, USA & 1998 & 22.7 & Sky Oaks Young stand, CA, USA & 1998 & 2021 \\
\hline Sky Oaks Old stand, CA, USA & 1997 & 21.0 & Skukuza, South Africa & 2003 & 1873 \\
\hline Santa Rita mesquite, AZ, USA & 2005 & 19.8 & Santa Rita mesquite, AZ, USA & 2005 & 1125 \\
\hline Kubuqi, shrubland, China & 2006 & 12.8 & Kubuqi, shrubland, China & 2006 & 1021 \\
\hline Karrykul, Turkmenistan & 2000 & 7.79 & Karrykul, Turkmenistan & 2000 & 769 \\
\hline \multicolumn{6}{|l|}{ Wetlands } \\
\hline Dongtan marsh-2, China & 2005 & 70.1 & Dongtan marsh-2, China & 2005 & 5643 \\
\hline CzechWet, Czech Republic & 2006 & 56.9 & CzechWet, Czech Republic & 2006 & 5368 \\
\hline Dongtan marsh-1, China & 2005 & 51.9 & Dongtan marsh-1, China & 2005 & 5150 \\
\hline Dongtan marsh-3, China & 2005 & 43.3 & Tadham Moore, United Kingdom & 2001 & 4767 \\
\hline Tadham Moore, United Kingdom & 2001 & 41.1 & Dongtan marsh-3, China & 2005 & 3662 \\
\hline PolWet, Poland & 2005 & 41.1 & PolWet, Poland & 2005 & 3393 \\
\hline Cherskii, Russia & 2003 & 20.1 & Siikaneva, Finland & 2005 & 1359 \\
\hline Kaamanen wetland, Finland & 2005 & 19.8 & Kaamanen wetland, Finland & 2005 & 1210 \\
\hline Siikaneva, Finland & 2004 & 19.8 & Cherskii, Russia & 2003 & 834 \\
\hline \multicolumn{6}{|l|}{ Croplands } \\
\hline Mead, maize rot. irrigated, NE, USA & 2001 & 116.1 & Langerak, The Netherlands & 2005 & 6774 \\
\hline Mead, maize cont. irrigated, NE, USA & 2001 & 107.8 & Mead, rot. maize irrigated, NE, USA & 2003 & 6720 \\
\hline Bondville, maize, IL, USA & 1999 & 99.9 & Borgo Cioffi-crop, Italy & 2005 & 6513 \\
\hline
\end{tabular}


Table 5. Continued.

\begin{tabular}{|c|c|c|c|c|c|}
\hline Site & Year & $\mathrm{g} \mathrm{CO}_{2} \cdot P_{\mathrm{g}, \max } \mathrm{m}^{-2} \cdot \mathrm{d}^{-1}$ & Site & Year & $\frac{\mathrm{GPP}}{\mathrm{g} \mathrm{CO}_{2} \cdot \mathrm{m}^{-2} \cdot \mathrm{yr}^{-1}}$ \\
\hline Batavia-agro, IL, USA & 2006 & 99.0 & Mead, cont. maize irrigated, NE, USA & 2001 & 6437 \\
\hline Bondville, maize, IL, USA & 1999 & 94.1 & Borgo Cioffi-crop, Italy & 2006 & 6393 \\
\hline Borgo Cioffi-crop, Italy & 2006 & 93.1 & Mead, maize rotation irrigated & 2001 & 6316 \\
\hline Mead, maize rainfed, NE, USA & 2003 & 87.6 & Lonzee, Belgium, sugar beet & 2005 & 6313 \\
\hline Langerak-crop, France & 2006 & 87.5 & Oensingen-crop, Switzerland & 2005 & 6295 \\
\hline Bondville-companion, IL, USA & 2006 & 83.03 & Mead maize rainfed, NE, USA & 2001 & 5834 \\
\hline Grignon-crop, France & 2005 & 81.3 & Bondville, maize, IL, USA & 1999 & 5602 \\
\hline Lonzee, winter wheat, Belgium & 2005 & 80.5 & Bondville, soybeans, IL, USA & 2005 & 5582 \\
\hline Bondville, soybeans, IL, USA & 2005 & 80.1 & Risbyholm, Denmark, crop & 2004 & 5525 \\
\hline \multicolumn{6}{|l|}{ Forests and plantations } \\
\hline Duke Forest Loblolly Pine, NC, USA & 2001 & 99.0 & French Guyana & 2004 & 14339 \\
\hline $\begin{array}{l}\text { Campbell River, British Columbia, } \\
\text { Canada }\end{array}$ & 1998 & 86.6 & Vanuatu - CocoFlux & 2002 & 13057 \\
\hline Hampshire Forest, United Kingdom & 2004 & 73.9 & Rondonia forest, Brazil & 2002 & 12727 \\
\hline Duke Forest Loblolly Pine & 2005 & 69.0 & Palangkaraya, Indonesia & 2003 & 12236 \\
\hline Vanuatu - CocoFlux & 2003 & 68.2 & Santarem km67 primary forest, Brazil & 2003 & 11703 \\
\hline Duke Forest Hardwood, NC, USA & 2003 & 67.6 & Caxiuana Forest-Almeirim, Brasil & 2002 & 11436 \\
\hline French Guyana & 2005 & 64.21 & Santarem km67 primary forest, Brazil & 2002 & 11271 \\
\hline Rondonia forest, Brazil & 2002 & 60.8 & Loblolly Pine plantation, NC, USA & 2006 & 10173 \\
\hline $\begin{array}{l}\text { Campbell River, British Columbia, } \\
\text { Canada }\end{array}$ & 2000 & 60.1 & Donaldson Slash Pine Plantation, FL, USA & 1999 & 9249 \\
\hline Loblolly Pine plantation, NC, USA & 2006 & 59.7 & Campbell River, British Columbia, Canada & 2005 & 9162 \\
\hline Duke Forest Hardwood, NC, USA & 2004 & 57.5 & Duke Forest Loblolly Pine, NC, USA & 2002 & 9067 \\
\hline $\begin{array}{l}\text { Donaldson Slash Pine Plantation, } \\
\text { FL, USA }\end{array}$ & 1999 & 54.6 & Duke Forest Hardwood, NC, USA & 2003 & 8892 \\
\hline
\end{tabular}

of the $\operatorname{IntNEE}(t)$ curve reflecting weather fluctuations and harvesting, which finally led to either net uptake (Fig. 7C) or net loss of carbon from the ecosystem (Figs. 7B, 7E, and 7H). Hendricks et al. (2007) described a case were S-shaped IntNEE dynamics was combined with significant net accumulation of carbon in a peat meadow ecosystem.

Year-round integration of the $P_{\mathrm{g}}(t), R_{\mathrm{e}}(t)$, and $\mathrm{F}_{\mathrm{c}}(t)$ curves provided estimates of annual GPP, RE, and NEE totals for all the site-years in this study. These data stratified by major ecosystem groups (extensively and intensively managed grasslands, shrublands and savanna, wetlands, and croplands) are summarized in Table 4 . The highest mean gross primary production $\left(6014 \mathrm{~g} \mathrm{CO}_{2} \cdot \mathrm{m}^{-2} \cdot \mathrm{yr}^{-1}\right)$ and ecosystem respiration $\left(5296 \mathrm{~g} \mathrm{CO}_{2} \cdot \mathrm{m}^{-2} \cdot \mathrm{yr}^{-1}\right)$ were achieved in intensively managed grasslands. Not surprisingly, the highest mean annual net ecosystem $\mathrm{CO}_{2}$ exchange $\left(933 \mathrm{~g} \mathrm{CO}_{2} \cdot \mathrm{m}^{-2} \cdot \mathrm{yr}^{-1}\right)$ was found in croplands.

To supplement these basic statistical characteristics, Figure 8 shows the distributions of GPP, RE, and NEE values in the pooled data set of estimates from all site-years in the database. They showed that the GPP and RE values in our sample varied widely $\left(95-8600 \mathrm{~g} \mathrm{CO}_{2} \cdot \mathrm{m}^{-2} \cdot \mathrm{yr}^{-1}\right.$ for gross production and 112-7880 $\mathrm{g} \mathrm{CO}_{2} \cdot \mathrm{m}^{-2} \cdot \mathrm{yr}^{-1}$ for respiration), with GPP and $\mathrm{RE}$ values fairly well distributed across their ranges (Figs. 8A and $8 \mathrm{~B})$. Net $\mathrm{CO}_{2}$ exchange values, however, concentrated between $-1342 \mathrm{~g} \quad \mathrm{CO}_{2} \cdot \mathrm{m}^{-2} \cdot \mathrm{yr}^{-1}$ and $2394 \mathrm{~g} \quad \mathrm{CO}_{2}$. $\mathrm{m}^{-2} \cdot \mathrm{yr}^{-1}$ and had a distinctly unimodal distribution (Fig. 8C). The average NEE value for our sample of 316 nonforest ecosystems was $485 \mathrm{~g} \mathrm{CO}_{2} \cdot \mathrm{m}^{-2} \cdot \mathrm{yr}^{-1}\left(\mathrm{SD}=696 \mathrm{~g} \mathrm{CO}_{2}\right.$. $\left.\mathrm{m}^{-2} \cdot \mathrm{yr}^{-1}\right)$. Comparing these statistics with the mean $(671 \mathrm{~g}$ $\left.\mathrm{CO}_{2} \cdot \mathrm{m}^{-2} \cdot \mathrm{yr}^{-1}\right)$ and standard deviation $\left(988 \mathrm{~g}^{-C_{2}}\right.$. $\mathrm{m}^{-2} \cdot \mathrm{yr}^{-1}$ ) of published NEE values for 506 site years from flux towers worldwide (Baldocchi 2008b), we did not detect a difference between the two NEE averages at the $1 \%$ level of significance. The higher mean NEE value for Baldocchi's sample can be explained by the number of growing forest sites with high NEE included in the sample, while the WORLDGRASSAGRIFLUX data set included mostly non-forest sites (with occasional near-climax shrubland and savanna ecosystems).

In the context of comparing basic parameters of the carbon cycle, it is particularly interesting to identify maximum rates of photosynthetic $\mathrm{CO}_{2}$ assimilation in various ecosystems. For this purpose, we compiled data of the 12 (or maximum available) site-years with maximum values of daily photosynthesis, $P_{\mathrm{g}, \max }$, and 12 (or maximum available) site-years with maximum annual GPP for our five types of nonforest ecosystems and for the forest sites represented in the most recent FLUXNET database (Table 5). For annual GPP, forest ecosystems achieved the highest estimates of photosynthetic $\mathrm{CO}_{2}$ uptake, with a maximum $\mathrm{GPP}=14339 \mathrm{~g} \quad \mathrm{CO}_{2}$. $\mathrm{m}^{-2} \cdot \mathrm{yr}^{-1}$ for a tropical forest in French Guyana (Table 5) compared to a maximum GPP $=8600 \mathrm{~g} \mathrm{CO}_{2} \cdot \mathrm{m}^{-2} \cdot \mathrm{yr}^{-1}$ for a tropical grassland in Rondonia, Brazil (Table 5). In contrast, maximum daily rates of photosynthetic uptake were found not in forests, but in the intensive crops of the midwestern United States, with $P_{\mathrm{g}, \max }=116 \mathrm{~g} \quad \mathrm{CO}_{2} \cdot \mathrm{m}^{-2} \cdot \mathrm{d}^{-1}$ estimated for 
irrigated maize in a maize-soybean rotation (Mead, NE) in 2001 (Table 5). These data clearly demonstrate that even in nonforest ecosystems such as shrublands and savanna, maximum rates of gross photosynthetic assimilation $\left(50-76 \mathrm{~g} \mathrm{CO}_{2} \cdot \mathrm{m}^{-2} \cdot \mathrm{d}^{-1}\right)$ were quite comparable to those of the most productive forests (55-99 $\left.\mathrm{g} \mathrm{CO}_{2} \cdot \mathrm{m}^{-2} \cdot \mathrm{d}^{-1}\right)$. A major reason why annual GPP in forests is typically higher than nonforested ecosystems is the length of production period. In tropical forests, production may encompass the whole year, whereas in most nonforest ecosystems production is temporally limited by temperature and water availability.

\section{Source/Sink Activity of Nonforest Ecosystems}

The data on annual budgets of production, respiration, and net $\mathrm{CO}_{2}$ exchange of nonforest ecosystems obtained in our study allowed a quantitative evaluation of important questions concerning the magnitude and significance of their source or sink activity. Since Odum (1956; see also Baldocchi 2008b), a convenient way to visualize the net $\mathrm{CO}_{2}$ budget of ecosystems for comparative purposes has been the use of RE vs. GPP scatter diagrams and comparison of the distribution of data points with respect to the 1:1 diagonal. Points below the diagonal correspond to sinks (GPP $>$ RE, NEE $>0$ ), whereas points above the diagonal describe sources of $\mathrm{CO}_{2}(\mathrm{GPP}<\mathrm{RE}, \mathrm{NEE}<0)$.

An Odum plot for the whole nonforest data set used in our study (Fig. 9) demonstrated that for four out of every five siteyears, gross production was higher than ecosystem respiration, indicating net ecosystem sink activity. Stratification of the data with respect to ecosystem type (Fig. 10) showed that there were considerably more years with net $\mathrm{CO}_{2}$ uptake than release for all types of nonforest ecosystems in our database. However, years with net source activity occasionally occurred over the study period in all ecosystems, except wetlands. It should be recognized that in managed nonforest ecosystems (as in managed forests), part of the carbon accumulation occurs in pools that may be exported off-site (as crop and forage harvest in nonforest ecosystems or as timber in forests).

The distributions of NEE for different ecosystems presented in Figure 11 provide a more detailed description of the matter. Source-type activity more frequently occurred in extensively managed grasslands, shrublands/savanna, and croplands than in intensively managed grasslands and wetlands. As a rule, source-type activity was associated with years of drought, excessive grazing and hay mowing, fire, high organic matter content of soils (e.g., grasslands on peat) or high $\mathrm{CaCO}_{3}$ stocks in the soil profile, and transitional successional status of the ecosystem (e.g., grasslands of previously forested soils; Meyers 2001; Emmerich 2003; Suyker et al. 2003; Novick et al. 2004; Jacobs et al. 2007). For agroecosystems, source activity was reported for crops such as soybeans, which typically involve intensive soil preparation and relatively short active growth periods (Baker and Griffis 2005). However, it should be emphasized that for the majority of ecosystems in our study, $\mathrm{CO}_{2}$ sink activity was frequently observed (from the atmospheric point of view), with the highest net carbon uptakes in intensively managed grasslands and cropland ecosystems, which are harvested once or several times each year and lead to off-site decomposition of the harvested products (Fig. 11, Table 4). In the past, a number of authors reported data that documented positive NEE values for grasslands and croplands (Svejcar et al. 1997; Dugas et al. 1999; Frank et al. 2001; Mielnick et al. 2001; Barcza et al. 2003; Suyker et al. 2003; Anthoni et al. 2004; Gilmanov et al. 2004; Xu and Baldocchi 2004; Gilmanov et al. 2005; Bernacchi et al. 2006; Gilmanov et al. 2006; Jaksic et al. 2006; Moureaux et al. 2006; Jacobs et al. 2007; Svejcar et al. 2008; Aubinet et al. 2009; Béziat et al. 2009). In our present analysis, we found predominantly positive annual NEE in managed grasslands and croplands based on a large number of geographically distributed flux monitoring stations from a variety of networks (Fig. 8C).

These observations contradict the conclusions of the first state of the carbon cycle report (SOCCR; King et al. 2007) and some earlier reports (e.g., Reicosky 1997; Smith and Falloon 2005), which assumed net source or neutral activity of agricultural ecosystems. These authors considered carbon stock changes, not the balance of $\mathrm{CO}_{2}$ fluxes exchanged with the atmosphere. In managed nonforest ecosystems, annual exports of organic matter by harvest imply that carbon storage does not vary in proportion to net balance of $\mathrm{CO}_{2}$ fluxes exchanged with atmosphere (Soussana et al. 2007). Our analysis shows a preponderance of data indicating predominantly positive net ecosystem $\mathrm{CO}_{2}$ exchange in grasslands and agroecosystems (Table 4, Figs. 8-11). Positive values of NEE based on $\mathrm{CO}_{2}$ flux measurements, however, do not necessarily mean there is an accumulation of carbon in the ecosystem, which may be lost as methane (Hendricks et al. 2007), or removed in nongaseous form with harvest or erosion. Given the role of harvest and anthropogenic management, results from our analysis indicate that the ability of managed agroecosystems and grasslands to serve as net sinks of $\mathrm{CO}_{2}$ from the atmosphere may be substantial, depending on the ultimate fate of the harvested biomass.

The need to recognize the sink activity of many grassland and agroecosystems to better understand the cycling of carbon at the landscape and regional level may be illustrated by imagining the vector field describing the movement of $\mathrm{CO}_{2}$ from the atmosphere to the ecosystem and back using a rather detailed space-time scale (e.g., 250-m 7-d MODIS). The $\mathrm{CO}_{2^{-}}$ NEE data (and methane and other gaseous forms of carbon exchange with the atmosphere, where measured) show that for many nonforest ecosystems, a particular pixel will have more arrows coming in than going out. Harvesting, erosion, and other forms of lateral transport of carbon in nongaseous form means that carbon is moved to other locations. Although the carbon eventually may be returned to the atmosphere in gaseous form, this release may occur from other pixels, often located far away from the original pixel into which the $\mathrm{CO}_{2}$ was assimilated. An independent validation of our conclusion about the predominant sink activity of managed grassland and agricultural ecosystems is provided by patterns of net $\mathrm{CO}_{2}$ exchange generated by the National Oceanic and Atmospheric Administration's CarbonTracker system based on precise measurements and modeling of atmospheric $\mathrm{CO}_{2}$ mole fractions (Peters et al. 2007; CarbonTracker 2009). Their map of the annual $\mathrm{CO}_{2}$ exchange for North America (Peters et al. 2007, fig. 1) shows significant carbon uptake in the Great Plains and the Midwest megaregions dominated by grassland and agroecosystems with the summary $\mathrm{CO}_{2}$ uptake of grassland and crop areas being higher than that of the largest North American sink, coniferous forests (Peters et al. 2007, fig. 2). 
The positive NEE values identified in the present study should stimulate efforts to combine flux measurements with full organic matter accounting, which so far has been implemented at only a few sites (Anthoni et al. 2004; Verma et al. 2005; Bernacchi et al. 2006; Amman et al. 2007; Soussana et al. 2007; Aubinet et al. 2009). In this context, it is also appropriate to consider the argument of Körner (2003) regarding the critical significance of the representativeness of flux-tower data sets and the "slow in, fast out" role of the biosphere in the dynamics of the carbon cycle. Recognizing the relevance of Körner's arguments to the situation in the early 2000s, it should be emphasized that, at least with regard to nonforest ecosystems, the present set of flux-tower sites that were analyzed in our study includes a wide range of sites with a large diversity of climatic conditions and management regimes. Therefore, data analyzed in the present study are much less biased toward highly productive ecosystems; however, southern hemisphere, south Asian, and African ecosystems tend to be underrepresented in the present analysis (Fig. 1).

\section{Ecosystem-Scale Production and Respiration in Relation to Major Ecological Factors}

Relationships of production and decomposition to major ecological factors attracted the attention of ecologists and geographers of the 20th century (Weaver 1924; Walter 1939; Budyko and Efimova 1968; Rosenzweig 1968; Lieth 1975) and were later approached under the framework of dynamic global vegetation models and related models (e.g., Woodward et al. 2001; Cramer et al. 2001). Presently, these problems are back in the focus of ecosystem and regional and global ecology, not only because of the recognition of their relevance to global climatic change, but also because today, for the first time, measurement-based quantitative estimates of gross productivity and total ecosystem respiration are readily available through processing of net $\mathrm{CO}_{2}$ exchange measurements at flux-tower sites (Aubinet et al. 2000; Baldocchi et al. 2001; Yaun et al. 2007; Zhang et al. 2007; Skinner et al. 2008).

Besides radiation and temperature, which are taken into account by the light-temperature-response function method, the next most important factor influencing ecosystem productivity and respiration is water (e.g., Slatyer 1967; Boyer 1982). Though water content or water potential of topsoil horizons are the most desirable predictors in production and decomposition modeling efforts, such data are not yet readily available for many flux-tower stations, making it necessary to use available precipitation data.

Both theory and empirical data indicate nonlinear relationships between photosynthesis, productivity, and decomposition rates and water content and/or water potential (Denmead and Shaw 1962; Wildung et al. 1975; Singh et al. 1980; Eastin and Sullivan 1984; Mielnick and Dugas 2000). In contrast, observations of the linear response of productivity in certain ecosystem types occasionally appear in the literature (Walter 1939; Le Houèrou and Hoste 1977; Sala et al. 1988). Our data allow a fresh look at this old problem by using new ecosystemscale estimates of GPP and RE values in relation to atmospheric precipitation (PCPN; Fig. 12). Within the whole data set, we found that the subsets of extensively managed grasslands, intensively managed grasslands, and shrublands-savanna ex-

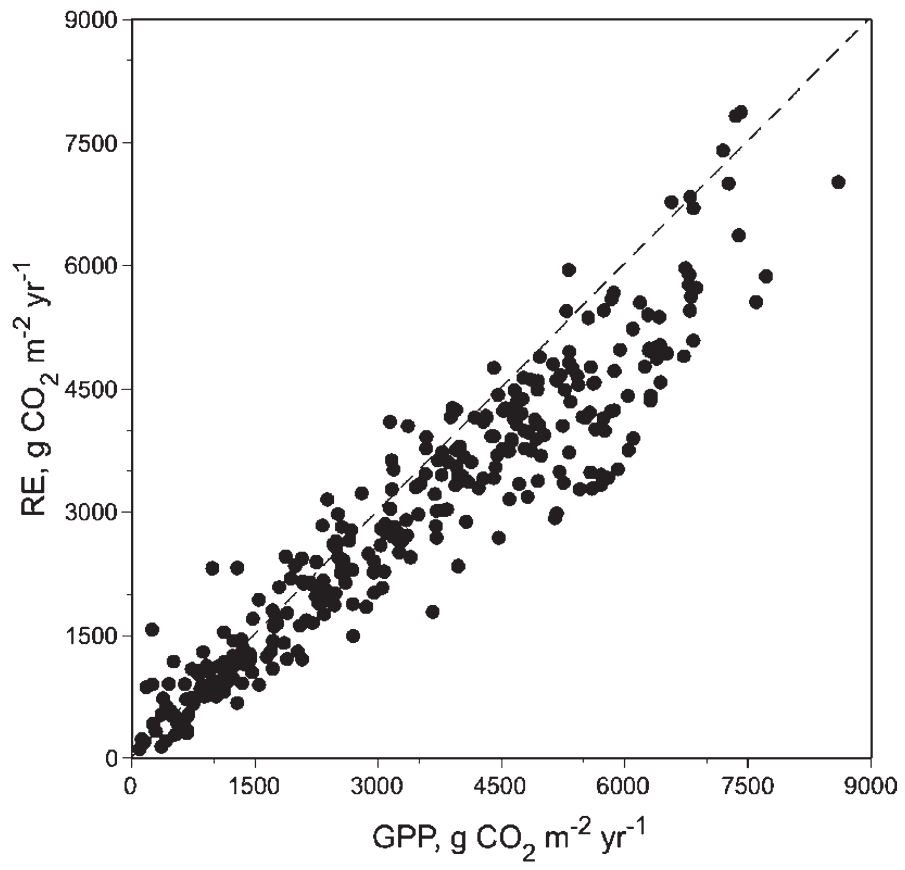

Figure 9. Scatter plot of ecosystem respiration (RE) vs. gross primary production (GPP) values for the pooled set of site-years from nonforest flux-tower stations of the world. The $1: 1$ diagonal is shown as a dashed line.

hibit patterns of the relationship of GPP and RE to precipitation and the dryness index. The data for wetlands and croplands, however, did not produce recognizable patterns, suggesting that modeling $\mathrm{CO}_{2}$ flux can be simplified by avoiding consideration of plant functional type and management in some cases.

Gross production and ecosystem respiration of extensively managed grasslands demonstrate nonlinear patterns in response to annual precipitation that may be expressed by Mitscherlich's equation (Figs. 12A and 12B), which describes a saturated relationship (cf. Lieth 1975). Deviation of the data points from the trend, which increases in amplitude with increasing precipitation, indicates a diminishing response to precipitation. As shown in Figures 12C and 12D, the decrease of precipitation-use efficiency is linked to the dryness index (ratio of annual net radiation, $R_{\text {net }}$, to the amount of energy required for evaporation of precipitation, $\lambda \times$ PCPN, where $\lambda$ is the latent heat coefficient; Budyko and Efimova 1968; Long et al. 1991).

\section{IMPLICATIONS}

The light-response parameters of nonforest terrestrial ecosystems have a wide range of variability, from relatively low values of photosynthetic capacity $\left(A_{\max }=0.2 \mathrm{mg} \quad \mathrm{CO}_{2}\right.$. $\mathrm{m}^{-2} \cdot \mathrm{s}^{-1}$ in drought-stressed grasslands), quantum yield $\left(\alpha=5 \mathrm{mmol} \cdot \mathrm{mol}^{-1}\right.$ in deserts), daytime ecosystem respiration $\left(r_{\mathrm{d}}=0.04 \mathrm{mg} \mathrm{CO} \cdot \mathrm{m}^{-2} \cdot \mathrm{s}^{-1}\right.$ in drought-stressed sagebrush steppe), and gross ecological light-use efficiency $(\varepsilon=2.6$ $\mathrm{mmol} \cdot \mathrm{mol}^{-1}$ in sedge and tussock tundras of Alaska), to the highest values ever recorded for terrestrial ecosystems (inten- 

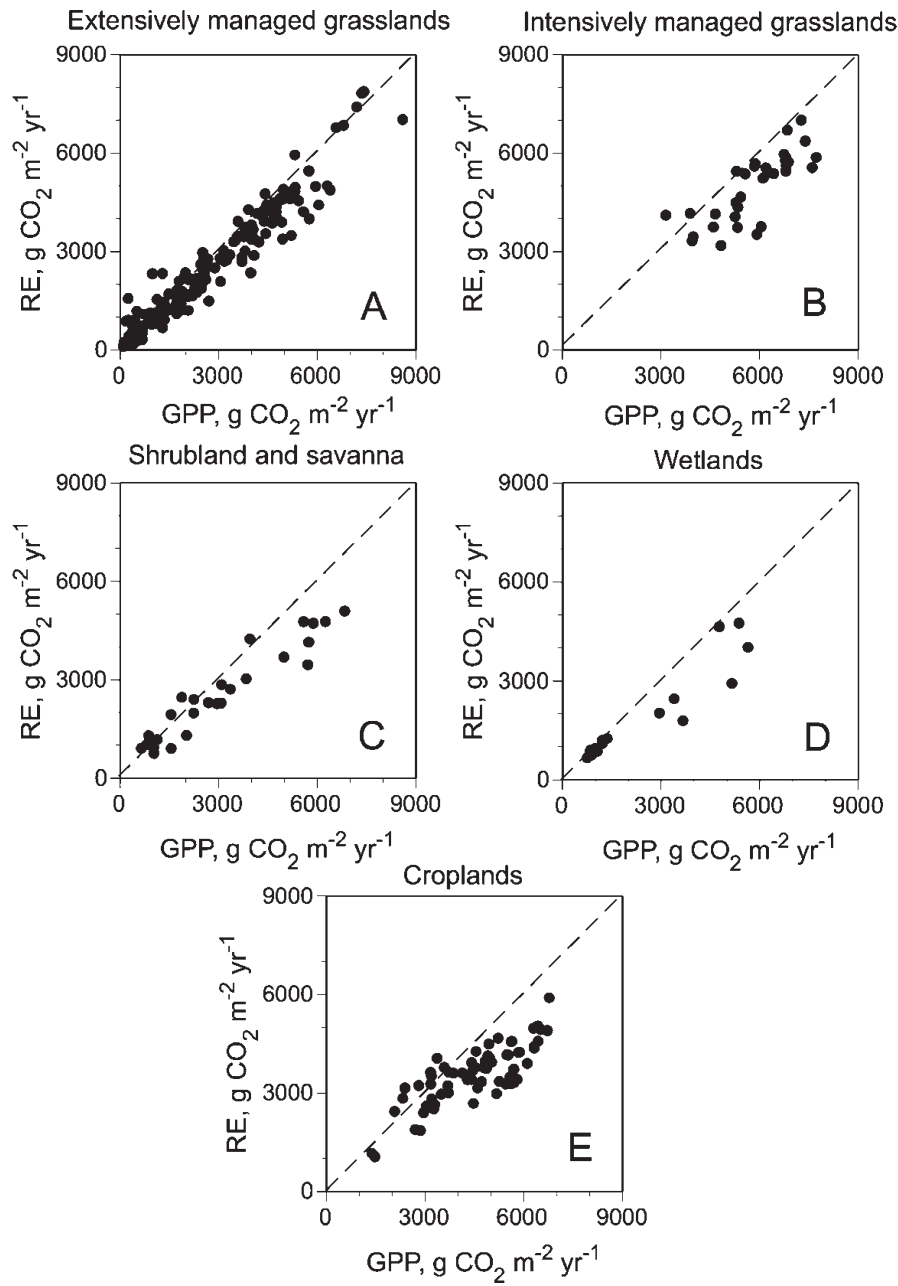

Figure 10. Scatter plots of the ecosystem respiration (RE) vs. gross primary production (GPP) values for various types of nonforest ecosystems: A, extensively managed grasslands; $\mathbf{B}$, intensively managed grasslands; C, shrublands and savanna; D, wetlands; E, croplands.

sively managed grasslands and agricultural crops: $A_{\max }=3.4 \mathrm{mg} \quad \mathrm{CO}_{2} \cdot \mathrm{m}^{-2} \cdot \mathrm{s}^{-1}, \quad \alpha=75 \mathrm{mmol} \cdot \mathrm{mol}^{-1}, \quad r_{\mathrm{d}}=$ $\left.0.50 \mathrm{mg} \mathrm{CO} 2 \cdot \mathrm{m}^{-2} \cdot \mathrm{s}^{-1}, \varepsilon=59 \mathrm{mmol} \cdot \mathrm{mol}^{-1}\right)$. Under optimal conditions, gross primary productivity in non-forest terrestrial ecosystems can surpass productivity of forests, with maximum rates of daily gross photosynthetic assimilation, $P_{\mathrm{g}, \max }$, achieving values greater than $100 \mathrm{~g} \quad \mathrm{CO}_{2} \cdot \mathrm{m}^{-2} \cdot \mathrm{d}^{-1}$ for intensive agricultural crops $\left(P_{\mathrm{g}, \max }=116 \mathrm{~g} \mathrm{CO}_{2} \cdot \mathrm{m}^{-2} \cdot \mathrm{d}^{-1}\right)$, whereas for forest ecosystems $P_{\mathrm{g} \text {,max }}$ values remain below $100 \mathrm{~g} \mathrm{CO}_{2} \cdot \mathrm{m}^{-2} \cdot \mathrm{d}^{-1}$ (FLUXNET data base: www.fluxdata. org). Nevertheless, because of limitations by radiation, temperature, water, and nutrient resources as well as management practices, maximum values of annual GPP of nonforest ecosystems estimated from flux-tower measurements remained below $10000 \mathrm{~g} \mathrm{CO}_{2} \cdot \mathrm{m}^{-2} \cdot \mathrm{yr}^{-1}$, whereas in many types of forests they considerably exceeded this value, with maximum GPP $>14000$ calculated for a tropical forest in French Guyana (Bonal et al. 2008). The annual values of both GPP and RE for extensively and intensively managed grasslands, and shrubland/ savanna ecosystems are nonlinearly associated with PCPN and dryness index, $R_{\text {net }} /(\lambda \times \mathrm{PCPN})$, indicating the potential sensitivity of these ecosystems to anthropogenic climate change.
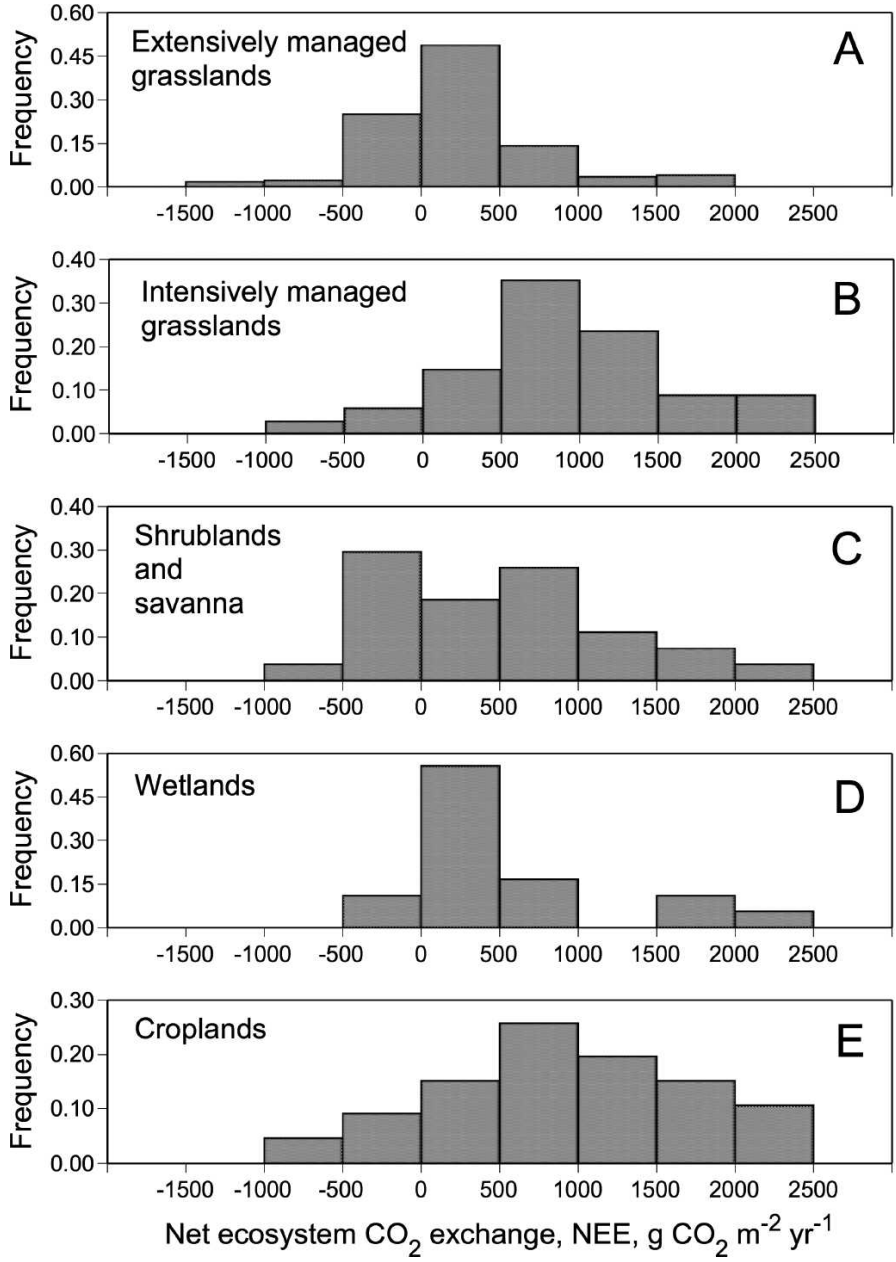

Figure 11. Histograms of statistical distributions of the annual net ecosystem $\mathrm{CO}_{2}$ exchange values (NEE) in various types of nonforest ecosystems: A, extensively managed grasslands; $\mathbf{B}$, intensively managed grasslands; C, shrublands and savanna; D, wetlands; E, croplands.
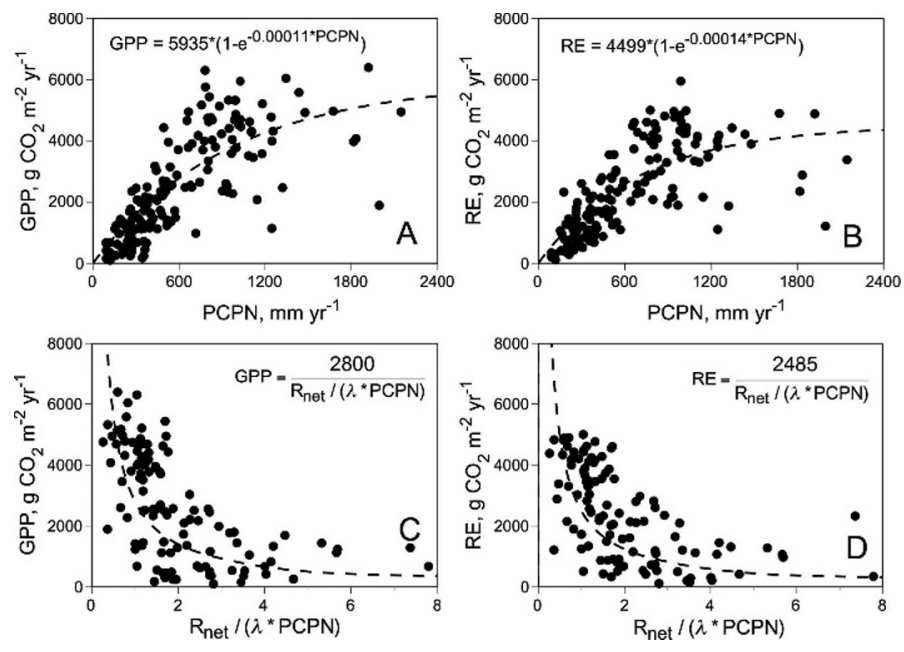

Figure 12. Response of gross primary production, GPP (A, C) and ecosystem respiration, $R E,(B, D)$ of extensively managed grasslands on the annual precipitation, PCPN $(\mathbf{A}, \mathbf{B})$ and the dryness index $\mathrm{DI}=R_{\text {net }} /$ $(\lambda \cdot P C P N)$. The dashed lines indicate nonlinear regressions describing predominant trends. 
The data in our sample of 316 annual net $\mathrm{CO}_{2}$ exchange values for nonforest ecosystems indicates that on average, nonforest ecosystems act as net biospheric sinks for atmospheric $\mathrm{CO}_{2}$, with the highest rates of net annual $\mathrm{CO}_{2}$ uptake occurring in agricultural crops (mean $\mathrm{NEE}_{\text {crop }}=933 \mathrm{~g} \mathrm{CO}_{2}$. $\mathrm{m}^{-2} \cdot \mathrm{yr}^{-1}$ ) and intensively managed grasslands (mean NEEgrassint $\left.=700 \mathrm{~g} \mathrm{CO}_{2} \cdot \mathrm{m}^{-2} \cdot \mathrm{yr}^{-1}\right)$. These data, based on continuous long-term flux-tower measurements, confirm that grasslands and agricultural crops play a significant role in the uptake of atmospheric $\mathrm{CO}_{2}$ and its transformation to biomass and soil organic matter (cf. Lal et al. 1998; Follett et al. 2001; Follett and Schuman 2005). These findings make it necessary to reconsider conclusions of earlier authors (e.g., Smith and Falloon 2005; Conant et al. 2007 in SOCCR) concerning the negative or neutral role that agroecosystems play in carbon budgets. These earlier studies, based on C-inventory methods and usually conducted at a regional scale, did not utilize fluxtower measurements. The tower measurements analyzed in our study documented the role of many nonforest ecosystems as $\mathrm{CO}_{2}$ sinks at the local scale. These results underscore the need to further examine the fate of carbon transported from grasslands and agroecosystems, and metabolized in and/or transported to other geographic locations. Clearly, further analyses are needed to determine the extent to which fluxtower networks and the geographic information systems and remote-sensing methods used to upscale flux measurements are representative, and to evaluate the significance of positive net $\mathrm{CO}_{2}$ exchange for the total carbon budget of managed grasslands and intensive agricultural crops (Barcza et al. 2009).

\section{ACKNOWLEDGMENTS}

We appreciate the efforts of those who have contributed data to the US Department of Agriculture-Agricultural Research Service RANGEFLUX, ${ }^{2}$ FLUXNET, ${ }^{3}$ and WORLDGRASSAGRIFLUX ${ }^{4}$ data sets: K. Akshalov, ${ }^{4}$ V. Allard, ${ }^{3,4}$ C. Ammann, ${ }^{3}$ M. Aubinet, ${ }^{3}$ M. Aurela, ${ }^{3}$ J. Baker, ${ }^{3,4}$ D. Baldocchi, ${ }^{3}$ J. Balogh, ${ }^{3}$ M. Balzarolo, ${ }^{3}$ C. Bernacchi,,${ }^{3,4}$ C. Bernhofer, ${ }^{3}$ P. Béziat, ${ }^{3}$ F. Bosveld, ${ }^{3}$ K. Brehe, ${ }^{4}$ N. Buchmann, ${ }^{3}$ P. Cellier, ${ }^{3}$ Shiping Chen, ${ }^{3}$ R. Coulter, ${ }^{3}$ R. Czerny, ${ }^{3}$ E. Dellwik, ${ }^{3}$ A. Detwiler, ${ }^{4}$ A. J. Dolman, ${ }^{3}$ W. Dugas, ${ }^{2}$ M. Durikov, ${ }^{4}$ J. Elbers, ${ }^{3}$ W. Emmerich, ${ }^{2}$ W. Eugster, ${ }^{3,4}$ D. Fitzjarrald, ${ }^{3}$ L. B. Flanagan, ${ }^{3,4}$ J. Fuhrer, ${ }^{3}$ T. Griffis, ${ }^{3,4}$ M. Haferkamp, ${ }^{2}$ R. Harding, ${ }^{3}$ A. Hensen, ${ }^{3}$ M. Heuer, ${ }^{3,4}$ S. Hollinger, ${ }^{3}$ D. Janous, ${ }^{3}$ W. Jans, ${ }^{3}$ T. Kato, ${ }^{3}$ G. Katul, ${ }^{3}$ D. Kliche, ${ }^{4}$ W. Kutsch, ${ }^{3}$ G. Lanigan, ${ }^{3}$ T. Laurila, ${ }^{4}$ P. Leahy, ${ }^{3}$ C. Lloyd, ${ }^{3}$ A. Lohila, ${ }^{4}$ A. Manzi, ${ }^{3}$ M. Marek, ${ }^{3}$ R. Matamala, ${ }^{3,4}$ T. Meyers, ${ }^{3,4}$ P. Mielnick, ${ }^{2}$ A. Miyata, ${ }^{3}$ J. Morgan, ${ }^{2}$ C. Moureaux, ${ }^{3,4}$ K. A. Novick, ${ }^{3}$ J. Olejnik, ${ }^{3}$ J. E. Olesen, ${ }^{3}$ W. Oechel, ${ }^{3}$ D. Papale, ${ }^{3}$ J. Prueger, ${ }^{4}$ A. Raschi, ${ }^{3}$, C. Rebmann, ${ }^{3}$ H. da Rocha, ${ }^{3}$ N. Rogiers, ${ }^{3,4}$ N. Saliendra, ${ }^{2}$ K. Schelde, ${ }^{3}$ R.H. Skinner, ${ }^{4}$ H. Soegaard, ${ }^{3}$ M. Sutton, ${ }^{3}$ A. Suyker, ${ }^{3}$ M. Torn, ${ }^{4}$ M. Urbaniak, ${ }^{3}$ S. Verma, ${ }^{3}$ M. Waterloo, ${ }^{3}$ G. Wohlfahrt, ${ }^{3,4}$ and B. Zhao. ${ }^{3}$ The authors thank managers of the RANGEFLUX database Patricia Mielnick and the FLUXNET database Dario Papale, Markus Reichstein, and Deb Agarwal for assistance with updating tower flux data. We also thank Mary Brooke McEachern for help with editing the manuscript of the article. FLUXNET data used in this work are the outcome of the La Thuile FLUXNET workshop 2007, which would not have been possible without the financial support provided by CarboEuropeIP, FAO-GTOS-TCO, iLEAPS, Max Planck Institute for Biogeochemistry, National Science Foundation, University of Tuscia, and US Department of Energy. Moreover, we acknowledge databasing and technical support from Surface Energy Balance Network (SEBN, formerly GEWEX), Berkeley Water Center, Lawrence Berkeley National Laboratory, Microsoft Research eScience, Oak Ridge National Laboratory, University of California-Berkeley, and University of Virginia. The following networks participated with flux data: AmeriFlux, AfriFlux, AsiaFlux, CarboAfrica, CarboEuropeIP, ChinaFlux, Fluxnet-Canada, KoFlux, LBA, NECC, OzFlux, TCOS-Siberia, USCCC. AmeriFlux grant: US Department of Energy, Biological and Environmental Research, Terrestrial Carbon Program (DE-FG02-04ER63917).

\section{LITERATURE CITED}

Agarwal, D., M. Humphrey, C. van Ingen, N. Beekwilder, M. Goode, K. Jackson, M. R. L. Rodriguez, and R. Weber. 2008. FluXNet synthesis dataset collaboration infrastructure. FluxLetter (The Newsletter of FLUXNET) 1:5-7.

Ammann, C., C. R. Flechard, J. Leifeld, A. Neftel, and J. Fuhrer. 2007. The carbon budget of newly established temperate grassland depends on management intensity. Agriculture, Ecosystems \& Environment 121:5-20.

Anthoni, P. M., A. Freibauer, O. Kolle, and E. D. Schulze. 2004. Winter wheat carbon exchange in Thuringia, Germany. Agricultural and Forest Meteorology 121:55-67.

Aubinet, M., A. Grelle, A. Ibrom, Ü. Rannik, J. Moncrieff, T. Foken, A. S. Kowalski, P. H. Martin, P. Berbigier, C. Bernhofer, R. Clement, J. Elbers, A. Granier, T. Grünwald, K. Morgenstern, K. Pilegaard, C. Rebmann, W. Snijders, R. Valentini, AND T. VESALA. 2000. Estimates of the annual net carbon and water exchange of forests: the EUROFLUX methodology. Advances in Ecological Research 30:113-175.

Aubinet, M., C. Moureaux, B. Bodson, D. Dufranne, B. Heinesch, M. Suleau, F. Vancutsem, and A. Vilret. 2009. Carbon sequestration by a crop over a 4-year sugar beet/winter wheat/seed potato/winter wheat rotation cycle. Agricultural and Forest Meteorology 149:407-418.

Austin, R. B., G. Kingston, P. C. Longden, and P. A. Donovan. 1978. Gross energy yields and the support energy requirements for the production of sugar from beet and cane: a study of four production areas. Journal of Agricultural Science 91:661-675.

BAKER, J. M., AND T. J. GRIFFIS. 2005. Examining strategies to improve the carbon balance of corn/bean agriculture using eddy covariance and mass balance techniques. Agricultural and Forest Meteorology 128:163-177.

BALDOCCHI, D. 2008a. Advanced topics in biometeorology and micrometeorology. Available at: http://nature.berkeley.edu/biometlab/espm228/. Accessed 30 November 2009.

BALDOCCHI, D. 2008b. "Breathing" of the terrestrial biosphere: lessons learned from a global network of carbon dioxide flux measurement systems. Australian Journal of Botany 56:1-26.

Baldocchi, D., E. Falge, L. Gu, R. J. Olson, D. Hollinger, S. Running, P. Anthoni, C. Bernhofer, K. Davis, R. Evans, J. Fuentes, A. Goldstein, G. Katul, B. Law, X. Lee, Y. Malhi, T. Meyers, W. Munger, W. Oechel, K. T. Paw U, K. Pilegaard, H. P. Schmid, R. Valentini, S. Verma, T. Vesala, K. Wilson, and S. WoFsY. 2001. FLUXNET: a new tool to study the temporal and spatial variability of ecosystem-scale carbon dioxide, water vapor, and energy flux densities. Bulletin of the American Meteorological Society 82: 2415-2434.

BALDOCCHI, D., AND L. Xu. 2005. Carbon exchange of deciduous broadleaved forests in temperate and Mediterranean regions. In: H. Griffiths and P. G. Jarvis [EDs.]. The carbon balance of forests. New York, NY, USA: Taylor and Francis. p. 187-215.

Barcza, Z., L. Haszpra, H. Kondo, N. Saigusa, S. Yamamoto, and J. Bartholy. 2003. Carbon exchange of grass in Hungary. Tellus B 55:187-196.

Barcza, Z., A. Kern, L. Haszpra, and N. KLJun. 2009. Spatial representativeness of tall eddy covariance measurements using remote sensing and footprint analysis. Agricultural and Forest Meteorology 149:795-807.

Bernacchi, C. J., S. E. Hollinger, and T. Meyers. 2006. Corrigendum: the conversion of the corn/soybean ecosystem to no-till agriculture may result in a carbon sink. Global Change Biology 12:1585-1586.

Béziat, P., E. Ceschia, and G. Dedieu. 2009. Carbon balance of a three crop succession over two cropland sites in South-West France. Agricultural and Forest Meteorology 149:1628-1645. 
Birdsey, R. A., J. C. Jenkins, M. Johnston, E. Huber-Sannwald, B. Amero, B. de Jong, J. D. E. Barra, N. R. French, F. Garcia-Oliva, M. Harmon, L. S. Heath, V. J. Jaramillo, K. Johnsen, B. E. Law, E. Martin-Spiotta, 0. Masera, R. Neilson, Y. Pan, and K. S. Pregitzer. 2007. North American forests. In: A. W. King, L. Dilling, G. P. Zimmerman, D. M. Fairman, R. A. Houghton, G. Marland, A. Z. Rose, and T. J. Wilbanks [EDS.]. The first state of the carbon cycle report (SOCCR): The North American carbon budget and implications for the global carbon cycle. A report by the U.S. Climate Change Science Program and the Subcommittee on Global Change Research. Asheville, NC, USA: National Oceanic and Atmospheric Administration, National Climatic Data Center. p. 117-126.

Blackman, F. F. 1905. Optima and limiting factors. Annals of Botany 19:281-295.

Bonal, D., A. Bosc, J. Y. Goret, B. Burban, P. Gross, J. M. Bonnefond, J. Elbers, S. Ponton, D. Epron, J. M. Guehl, and A. Granier. 2008. The impact of severe dry season on net ecosystem exchange in the Neotropical rainforest of French Guiana. Global Change Biology 14:1917-1933.

BoYeR, J. S. 1982. Plant productivity and environment. Science 218:443-448.

Bridgham, S. D., J. P. Megonigal, J. K. Keller, N. B. Bliss, and C. Trettin. 2007. Wetlands. In: A. W. King, L. Dilling, G. P. Zimmerman, D. M. Fairman, R. A Houghton, G. Marland, A. Z. Rose, and T. J. Wilbanks [EDS.]. The first state of the carbon cycle report (SOCCR): the North American carbon budget and implications for the global carbon cycle. A report by the U.S. Climate Change Science Program and the Subcommittee on Global Change Research. Asheville, NC, USA: National Oceanic and Atmospheric Administration, National Climatic Data Center. p. 117-126.

Budyko, M. I., And N. A. EFIMova. 1968. The use of solar energy by the natural plant cover of the USSR. Botanicheskii Zhurnal 53:1384-1389.

BuRBa, G., And D. Anderson. 2007. Introduction to the eddy covariance method. General guidelines, and conventional workflow. LI-COR Biosciences. Available at: http://www.licor.com/env/PDF_Files/EddyCovariance_readonly.pdf. Accessed 30 November 2009.

Buyanovsky, G. A., and G. H. Wagner. 1998. Changing role of cultivated land in the global carbon cycle. Biology and Fertility of Soils 27:242-245.

CARBonTraCKER. 2009. Available at: http://www.esrl.noaa.gov/gmd/ccgg/carbontracker/. Accessed 30 November 2009.

Ciais, P., P. Friedlingstein, A. Friend, and D. S. Schimel. 2001. Integrating global models of terrestrial primary productivity. In: J. Roy, B. Saugier, and H. A. Mooney [Eds.]. Terrestrial global productivity. San Diego, CA, USA: Academic Press. p. 449-478.

Colinvaux, P. A. 1993. Ecology 2. New York, NY, USA: Wiley. 688 p.

Conant, R. T., K. Paustian, F. Garcia-Oliva, H. H. Janzen, M. J. Jaramillo, D. E. Johnson, and S. N. KulshreShtha. 2007. Agricultural and grazing lands. In: A. W. King, L. Dilling, G. P. Zimmerman, D. M. Fairman, R. A. Houghton, G. Marland, A. Z. Rose, and T. J. Wilbanks [EDS.]. The first state of the carbon cycle report (SOCCR): The North American carbon budget and implications for the global carbon cycle. A report by the U.S. Climate Change Science Program and the Subcommittee on Global Change Research. Asheville, NC, USA: National Oceanic and Atmospheric Administration, National Climatic Data Center. p. 107-116.

COoPER, J. P. 1970. Potential production and energy conversion in temperate and tropical grasses. Herbage Abstracts 40:1-13.

Cramer, W., R. J. Olson, S. D. Prince, and J. M. 0. Scurlock and members of the Global Primary Production Data Initiative. 2001. Determining present patterns of global productivity. In: J. Roy, B. Saugier, and H. A. Mooney [EDs.]. Terrestrial global productivity. San Diego, CA, USA: Academic Press. p. 429-448.

Davidson, E. A., and I. A. Janssens. 2006. Temperature sensitivity of soil carbon decomposition and feedbacks to climate change. Nature 440:165-173.

Denmead, 0. T., and R. H. Shaw. 1962. Availability of soil water to plants as affected by soil moisture content and meteorological conditions. Agronomy Journal 54:385-390

Dugas, W. A., M. L. Heuer, and H. S. Mayeux. 1999. Carbon dioxide fluxes over bermudagrass, native prairie, and sorghum. Agricultural and Forest Meteorology 93:121-139.

EAstin, J. D., AND C. Y. Sullivan. 1984. Environmental stress influences on plant persistence, physiology, and production. In: M. B. Tesar [ED.]. Physiological basis of crop growth and development. Madison, WI, USA: American Society of Agronomy and Crop Science Society of America. p. 201-236.

Emmerich, W. E. 2003. Carbon dioxide fluxes in a semiarid environment with high carbonate soils. Agricultural and Forest Meteorology 116:91-102.

Falge, E., J. Tenhunen, D. Baldocchi, M. Aubinet, P. Bakwin, P. Berbigier, C. Bernhofer, J. M. Bonnefond, G. Burba, R. Clement, K. J. Davis, J. A. Elbers, M. Falk, A. H. Goldstein, A. Grelle, A. Granier, T. Grünwald, J. Gudmundsson, D. Hollinger, I. A. Janssens, P. Keronen, A. S. Kowalski, G. Katul, B. E. Law, Y. Malhi, T. Meyers, R. K. Monson, E. Moors, J. W. Munger, W. Oechel, K. T. P. U. K. Pilegaard, U. Rannik, C. Rebmann, A. Suyker, H. Thorgeirsson, G. Tirone, A. Turnipseed, K. Wilson, and S. Wofsy. 2002. Phase and amplitude of ecosystem carbon release and uptake potentials as derived from FLUXNET measurements. Agricultural and Forest Meteorology 113:75-95.

Farrell, A. E., M. O'Hare, D. M. Kammen, R. J. Plevin, B. T. Turner, and A. D. Jones. 2006. Ethanol can contribute to energy and environmental goals. Science 311:506-508.

Follett, R. F., J. M. Kimble, and R. Lal [eds.]. 2001. The potential of U.S. grazing lands to sequester carbon and mitigate the greenhouse effect. Boca Raton, FL, USA: Lewis Publishers. $442 \mathrm{p}$.

Follett, R. F., and G. E. Schuman. 2005. Grazing land contributions to carbon sequestration. In: D. A. McGilloway [ED.]. Grassland: a global resource. Wageningen, the Netherlands: Wageningen Academic Publishers. p. 265-277.

Frank, A. B., P. L. Sims, J. A. Bradford, P. C. Mielnick, W. A. Dugas, and H. S. Mayeux. 2001. Carbon dioxide fluxes over three Great Plains grasslands. In: R. F. Follett, J. M. Kimble, and R. Lal [EDS.]. The potential of U.S. grazing lands to sequester carbon and mitigate the greenhouse effect. Boca Raton, FL, USA: Lewis Publishers. p. 167-187.

Funk, J. L., and M. T. Lerdau. 2004. Photosynthesis in forest canopies. In: M. D. Lowman and H. B. Rinker [EDS.]. Forest canopies. Amsterdam, the Netherlands: Elsevier Academic Press. p. 335-358.

Gilmanov, T. G., A. B. Frank, M. R. Haferkamp, T. P. Meyers, J. A. Morgan, L. L. Tieszen, B. K. Wylie, and L. B. Flanagan. 2005. Integration of $\mathrm{CO}_{2}$ flux and remotelysensed data for primary production and ecosystem respiration analyses in the Northern Great Plains: potential for quantitative spatial extrapolation. Global Ecology and Biogeography 14:271-292.

Gilmanov, T. G., D. A. Johnson, and N. Z. Saliendra. 2003a. Growing season $\mathrm{CO}_{2}$ fluxes in a sagebrush-steppe ecosystem in Idaho: Bowen ratio/energy balance measurements and modeling. Basic and Applied Ecology 4:167-183.

Gilmanov, T. G., D. A. Johnson, N. Z. Saliendra, K. Akshalov, and B. K. Wylie. 2004. Gross primary productivity of the true steppe in Central Asia in relation to NDVI: scaling-up $\mathrm{CO}_{2}$ fluxes. Environmental Management 39:S492-S508.

Gilmanov, T. G., J. F. Soussana, L. Aires, V. Allard, C. Ammann, M. Balzarolo, Z. Barcza, C. Bernnhofer, C. L. Campbell, A. Cernusca, A. Cescatti, J. CliftonBrown, B. 0. M. Dirks, S. Dore, W. Eugster, J. Fuhrer, C. Gimeno, T. Gruenwald, L. Haszpra, A. Hensen, A. Ibrom, A. F. G. Jacobs, M. B. Jones, G. Lanigan, T. Laurila, A. Lohila, G. Manca, B. Marcolla, Z. Nagy, K. Pilegaard, K. Pinter, C. Pio, A. Raschi, N. Rogiers, M. J. Sanz, P. Stefani, M. Sutton, Z. Tuba, R. Valentini, M. L. Williams, and G. Wohlfahrt. 2007. Partitioning European grassland net ecosystem $\mathrm{CO}_{2}$ exchange into gross primary productivity and ecosystem respiration using light response function analysis. Agriculture, Ecosystems and Environment 121:93-120.

Gilmanov, T. G., T. J. Svejcar, D. A. Johnson, R. F. Angell, N. Z. Saliendra, and B. K. WYLIE. 2006. Long-term dynamics of production, respiration, and net $\mathrm{CO}_{2}$ exchange in two sagebrush-steppe ecosystems. Rangeland Ecology and Management 59:585-599.

Gillmanov, T. G., S. B. Verma, P. L. Sims, T. P. Meyers, J. A. Bradford, G. G. Burba, AND A. E. SUYKer. 2003b. Gross primary production and light response parameters of four Southern Plains ecosystems estimated using long-term $\mathrm{CO}_{2}$-flux tower measurements. Global Biogeochemical Cycles 17, doi: 10.1029/2002GB002023.

Gilmanov, T. G., and WORldgrassagrifluX Data Set Participants. 2007. Productivity, respiration, $\mathrm{CO}_{2}$ sink potential, and light-response parameters of world grasslands derived from flux-tower data partitioning. Eos, Transactions, American Geophysical Union, Fall Meeting Supplement 88(52):Abstract B32B-03. 
Good, N. E., And D. H. Bell. 1980. Photosynthesis, plant productivity and crop yield. In: P. S. Carlson [ED.]. The biology of crop productivity. New York, NY, USA: Academic Press. p. 3-51.

Goulden, M. L., J. W. Munger, S. M. Fan, B. C. Daube, and S. C. Wofsy. 1996. Measurements of carbon sequestration by long-term eddy covariance: methods and critical evaluation of accuracy. Global Change Biology 2:169-182.

GrifFiths, H., and P. Jarvis [eds.]. 2005. The carbon balance of forest biomes. New York, NY, USA: Taylor \& Francis.

Hendricks, D. M. D., J. van Huissteden, A. J. Dolman, and M. K. van der Molen. 2007. The full greenhouse gas balance of an abandoned peat meadow. Biogeosciences 4:414-424.

Jacobs, C. M. J., A. F. G. Jacobs, F. C. Bosveld, D. M. D. Hendriks, A. Hensen, P. S. Kroon, E. J. Moors, L. Nol, A. Schrier-UiJl, and E. M. Veenendaal. 2007. Variability of annual $\mathrm{CO}_{2}$ exchange from Dutch grasslands. Biogeosciences Discussions 4:1499-1534.

Jaksic, V., G. Kiely, J. Albertson, R. Oren, G. Katul, P. Leahy, and K. A. Byrne. 2006. Net ecosystem exchange of grassland in contrasting wet and dry years. Agricultural and Forest Meteorology 139:323-334.

JaRvis, P. G. 1994. Capture of carbon dioxide by a coniferous forest. In: J. L. Monteith, R. K. Scott, and M. H. Unsworth [EDS.]. Resource capture by crops. Loughborough, Leicestershire, United Kingdom: Nottingham University Press. p. 351-374.

King, A. W., L. Dilling, G. P. Zimmerman, D. M. Fairman, R. A. Houghton, G. Marland, A. Z. Rose, and T. J. Wilbanks [Eds.]. 2007. The first state of the carbon cycle report (SOCCR): the North American carbon budget and implications for the global carbon cycle. A report by the U.S. Climate Change Science Program and the Subcommittee on Global Change Research. Asheville, NC, USA: National Oceanic and Atmospheric Administration, National Climatic Data Center. $240 \mathrm{p}$.

KöRner, C. 2003. Slow in, rapid out-carbon flux studies and Kyoto target. Science 300:1242-1243.

Lal, R., J. M. Kimble, R. F. Follett, and C. V. Cole [eds.]. 1998. The potential of U.S. cropland to sequester carbon and mitigate the greenhouse effect. Chelsea, MI, USA: Ann Arbor Press. 128 p.

LARCher, W. W. 1995. Physiological plant ecology: ecophysiology and stress physiology of functional groups. Berlin, Germany: Springer-Verlag. 506 p.

Le Houèrou, H. N., AND C. H. Hoste. 1977. Rangeland production and annual rainfall relations in the Mediterranean basin and in the African Sahelo-Sudanian Zone. Journal of Range Management 30:181-189.

LeE, X., W. Massman, and B. Law [eds.]. 2004. Handbook of micrometeorology: a guide for surface flux measurement and analysis. Dordrecht, the Netherlands: Kluwer Academic Publishers. $250 \mathrm{p}$.

LIETH, H. 1975. Modeling the primary productivity of the world. In: H. Lieth and R. H. Whittaker [EDS.]. Primary productivity of the biosphere. New York, NY, USA: Springer-Verlag. p. 237-263.

Loehle Enterprises. 2007. Global optimization 6.0. Global nonlinear optimization using Mathematica. Naperville, IL, USA: Loehle Enterprises.

Long, S. P., M. B. Jones, and M. J. Roberts [eds.]. 1991. Primary productivity of grass ecosystems of the tropics and sub-tropics. London, United Kingdom: Chapman \& Hall. 267 p.

MeYeRS, T. P. 2001. A comparison of summertime water and $\mathrm{CO}_{2}$ fluxes over rangeland for well watered and drought conditions. Agricultural and Forest Meteorology 106:205-214.

Mielnick, P. C., and W. A. Dugas. 2000. Soil $\mathrm{CO}_{2}$ flux in a tallgrass prairie. Soil Biology and Biochemistry 32:221-228.

Mielnick, P. C., W. A. Dugas, H. B. Johnson, H. W. Polley, and J. Sanabria. 2001. Net grassland carbon flux over a subambient to superambient $\mathrm{CO}_{2}$ gradient. Global Change Biology 7:747-754.

Mitscherlich, E. A. 1909. Das Gesetz des Minimums und das Gesetz des abnehmenden Bodenertrages. Landwirtschaftliches Jahrbuch der Schweiz 38:537-552.

Moffat, A. M., D. Y. Hollinger, A. D. Richardson, A. G. Barr, C. Beckstein, B. H. Braswell, G. Churkina, A. R. Desal, E. Falge, J. H. Gove, M. Heimann, D. Hui, A. J. Jarvis, J. Kattge, A. Noormets, V. J. Stauch, D. Papale, and M. Reichstein.
2007. Comprehensive comparison of gap-filling techniques for eddy covariance net carbon fluxes. Agricultural and Forest Meteorology 147:209-232.

Monteith, J. L. 1972. Solar radiation and productivity in tropical ecosystems. Journal of Applied Ecology 9:747-766.

MordacQ, L., J. Ghasghaie, and B. Saugier. 1991. A simple method for measuring the gas exchange of small trees. Functional Ecology 5:572-576.

Moureaux, C., A. Debaco, B. Bodson, B. Heinesch, and M. Aubinet. 2006. Annual net ecosystem carbon exchange by a sugar beet crop. Agricultural and Forest Meteorology 139:25-39.

Novick, K. A., M. B. S. Siqueira, J. Juang, R. Oren, P. C. Stoy, G. G. Katul, and D. S. ElLsworth. 2004. Carbon dioxide and water vapor exchange in a warm temperate grassland. Oecologia 138:259-274.

Odum, E. P. 1959. Fundamentals of ecology. Philadelphia, PA, USA: Saunders. $384 \mathrm{p}$.

Odum, H. T. 1956. Primary production in flowing waters. Limnology and Oceanography 1:102-117.

OLSon, J. S., J. A. WATtS, AND L. J. AlLISON. 1983. Carbon in live vegetation of major world ecosystems. Washington, DC, USA: US Department of Energy, Oak Ridge National Laboratory Technical Report ORNL-5862. $152 \mathrm{p}$.

Owen, K. E., E. Falge, R. Geyer, X. Xiao, P. Stoy, C. Ammann, A. Arain, M. Aubinet, M. Aurela, C. Bernhofer, B. H. Chojnicki, A. Granier, T. Gruenwald, J. Hadley, B. Heinesch, D. Hollinger, A. Knohl, W. Kutsch, A. Lohila, T. Meyers, E. Moors, C. Moureaux, K. Pilegaard, N. Saigusa, S. Verma, T. Vesala, C. Vogel, J. Tenhunen, M. Reichstein, and Q. Wang. 2007. Linking flux network measurements to continental scale simulations: ecosystem carbon dioxide exchange capacity under non-water-stressed conditions. Global Change Biology 13:734-760.

Patzek, T. W., J. Lee, B. Li, J. Padnick, S. A. Yee, S. M. Anti, R. Campos, and K. W. Ha. 2005. Ethanol from corn: clean renewable fuel for the future, or drain on our resources and pockets? Environment, Development and Sustainability 7:319-336.

Peters, W., A. R. Jacobson, C. Sweeney, A. E. Andrews, T. J. Conway, K. Masarie, J. B. Miller, L. M. P. Bruhwiler, G. Pétron, A. I. Hirsch, D. E. J. Worthy, G. R. van der Werf, J. T. Randerson, P. O. Wennberg, M. Krol, and P. P. Tans. 2007. An atmospheric perspective on North American carbon dioxide exchange: CarbonTracker. Proceedings of the National Academy of Sciences of the United States of America 104:18925-18930.

Powlson, D. S., A. B. Riche, And I. Shield. 2005. Biofuels and other approaches for decreasing fossil fuel emissions from agriculture. Annals of Applied Biology 146:193-201.

RabinowICH, E. I. 1951. Photosynthesis and related processes. New York, NY, USA: Interscience Publishers. $1208 \mathrm{p}$.

Reichstein, M., E. Falge, D. Baldocchi, D. Papale, R. Valentini, M. Aubinet, P. Berbigier, C. Bernhofer, N. Buchmann, M. Falk, T. Gilmanov, A. Granier, T. Grünwald, K. Havránková, D. Janous, A. Knohl, T. Laurela, A. Lohila, D. Loustau, G. Matteucci, T. Meyers, F. Miglietta, J. M. Ourcival, D. Perrin, J. Pumpanen, S. Rambal, E. Rotenberg, M. Sanz, J. Tenhunen, G. Seufert, F. Vaccari, T. Vesala, AND D. YakiR. 2005. On the separation of net ecosystem exchange into assimilation and ecosystem respiration: review and improved algorithm. Global Change Biology 11:1424-1439.

Reıcosky, D. C. 1997. Tillage-induced $\mathrm{CO}_{2}$ emission from soil. Nutrient Cycling in Agroecosystems 49:273-285.

Rodin, L. E., AND N. I. BAZILEVICH. 1968. Production and mineral cycling in terrestrial vegetation. Edinburgh, Scotland: Oliver and Boyd. $288 \mathrm{p}$.

RosenzWEIG, M. L. 1968. Net primary production of terrestrial communities: prediction from climatological data. American Naturalist 102:67-74.

Ruimy, A., P. G. Jarvis, AND D. D. BaLdocCH. 1995. $\mathrm{CO}_{2}$ fluxes over plant canopies and solar radiation: a review. Advances in Ecological Research 26:1-68.

Sala, O. E., W. J. Parton, L. A. Joyce, and W. K. Lauenroth. 1988. Primary production of the central grassland region of the United States. Ecology 69:40-45.

Singh, J. S., M. J. Trlica, P. G. Risser, R. E. Redmann, and J. K. Marshall. 1980. Autotrophic subsystem. In: A. I. Breymeyer and G. M. Van Dyne [EDS.]. Grasslands, systems analysis and man. Cambridge, United Kingdom: Cambridge University Press. p. 59-200. 
Skinner, R. H., M. S. Corson, and T. G. Gilmanov. 2008. Simulating pasture photosynthesis and respiration. Agronomy Journal 100:801-807.

SlatYeR, R. 0. 1967. Plant-water relationships. New York, NY, USA: Academic Press. $366 p$.

Smith, P., and P. Falloon. 2005. Carbon sequestration in European croplands. In: H. Griffiths and P. G. Jarvis [EDs.]. The carbon balance of forest biomes. New York, NY, USA: Taylor and Francis. p. 47-55.

Soussana, J. F., V. Allard, K. Pilegaard, P. Ambus, C. Amman, C. Campbell, E. Ceschia, J. Clifton-Brown, S. Czobel, R. Domingues, C. Flechard, J. Fuhrer, A. Hensen, L. Horvath, M. Jones, G. Kasper, C. Martin, Z. Nagy, A. Neftel, A. Raschi, S. Baronti, R. M. Rees, U. Skiba, P. Stefani, G. Manca, M. Sutton, Z. Tubaf, and R. ValentinI. 2007. Full accounting of the greenhouse gas $\left(\mathrm{CO}_{2}, \mathrm{~N}_{2} \mathrm{O}, \mathrm{CH}_{4}\right)$ budget of nine European grassland sites. Agriculture, Ecosystems and Environment. The Greenhouse Gas Balance of Grasslands in Europe 121:121-134

Stoy, P. C., J. Y. Juang, K. A. Novick, J. M. Uebelherr, R. Oren, G. G. Katul, and M. B. S. SIQuelRA. 2006. An evaluation of models for partitioning eddy covariance-measured net ecosystem exchange into photosynthesis and respiration. Agricultural and Forest Meteorology 141:2-18.

Suyker, A. E., S. B. Verma, And B. G. G. 2003. Interannual variability in net $\mathrm{CO}_{2}$ exchange of a native tallgrass prairie. Global Change Biology 9:255-265.

Svejcar, T., R. Angell, J. Bradford, W. Dugas, W. Emmerich, A. Frank, T. Gilmanov, M. Haferkamp, D. Johnson, H. Mayeux, P. Mielnick, J. Morgan, N. Saliendra, G. Schuman, P. Sims, and K. Snyder. 2008. Carbon fluxes on North American rangelands. Rangeland Ecology and Management 61:465-474.

Svejcar, T., H. Mayeux, and R. Angell. 1997. The rangeland carbon dioxide flux project. Rangelands 19:16-18.

TAMiYA, H. 1951. Some theoretical notes on the kinetics of algal growth. Botanical Magazine 6:167-173.

Tarnocal, C., C. L. Ping, and J. Kimble. 2007. Carbon cycle in the permafrost region of North America. In: A. W. King, L. Dilling, G. P. Zimmerman, D. M. Fairman, R. A. Houghton, G. Marland, A. Z. Rose, and T. J. Wilbanks [eDs.]. The first state of the carbon cycle report (SOCCR): The North American carbon budget and implications for the global carbon cycle. A report by the U.S. Climate Change Science Program and the Subcommittee on Global Change Research. Asheville, NC, USA: National Oceanic and Atmospheric Administration, National Climatic Data Center. p. 127-138.

Thornley, J. H. M., and I. R. Johnson. 2000. Plant and crop modelling. A mathematical approach to plant and crop physiology. Caldwell, NJ, USA: The Blackburn Press. $669 p$

Verma, S. B., A. Dobermann, K. G. Cassman, D. T. Walters, J. M. Knops, T. J. Arkebauer, A. E. Suyker, G. G. Burba, B. Amos, H. Yang, D. Ginting, K. G. Hubbard, A. A. Gitelson, and E. A. Walter-Shea. 2005. Annual carbon dioxide exchange in irrigated and rainfed maize-based agroecosystems. Agricultural and Forest Meteorology 131:77-96.

WaLter, H. 1939. Grassland, Savanne und Busch der ariden Teile Afrikas in ihrer ökologische Bedingtheit. Jahrbuch fur wissenschaftliche Botanik 87:850860

WeAver, J. E. 1924. Plant production as a measure of environments. Journal of Ecology 12:205-237.

Whittaker, R. H., and G. E. Likens. 1973. Carbon in the biota. In: G. M. Woodwell and E. V. Pecan [EDs.]. Carbon and the biosphere. Springfield, VA, USA: National Technical Information Service. p. 281-302.

Wildung, R. E., T. R. Garland, and R. L. Buschbom. 1975. The interdependent effects of soil temperature and water content on soil respiration rate and plant root decomposition in arid grassland soils. Soil Biology and Biochemistry 7:373-378.

Wohlfahrt, G., C. Newesely, A. Cernusca, M. Bahn, and A. Haslwanter. 2005. Estimation of daytime ecosystem respiration to determine gross primary production of a mountain meadow. Agricultural and Forest Meteorology 130:13-25.

Wolfram Research. 2009. Wolfram Mathematica 7. Complete Documentation. Available at: http://reference.wolfram.com/mathematica/guide/Mathematica. html. Accessed 30 November 2009.
Woodward, F. I., M. R. Lomas, and S. E. LeE. 2001. Predicting the future productivity and distribution of global terrestrial vegetation. In: J. Roy, B. Saugier, and H. A. Mooney [EDS.]. Terrestrial global productivity. San Diego, CA, USA: Academic Press. p. 521-541.

XU, L., AND D. D. BALDoCCHI. 2004. Seasonal variation in carbon dioxide exchange over a Mediterranean annual grassland in California. Agricultural and Forest Meteorology 123:79-96.

Yuan, W., G. Zhou, L. L. Tieszen, D. Baldocchi, C. Bernhofer, H. Gholz, A. H. Goldstein, M. L. Goulden, D. Y. Hollinger, Y. Hu, B. E. Law, P. C. Stoy, T. Vesala, S. C. WofsY, AND S. LIU. 2007. Deriving a light use efficiency model from eddy covariance flux data for predicting daily gross primary production across biomes. Agricultural and Forest Meteorology 143:189-207.

Zhang, L., E. Fosnight, L. L. Tieszen, L. Jl, T. Gilmanov, B. Wylie, and T. Loveland. 2007. Evaluation and comparison of gross primary production estimates for the Northern Great Plains grasslands. Remote Sensing of Environment 106:173-189.

Zhang, L. M., Y. Gui-Rui, X. M. Sun, X. F. Wen, C. Y. Ren, Y. L. Fu, Q. K. Li, Z. Q. Li, Y. F. LiU, D. X. Guan, and J. H. Yan. 2006. Seasonal variation of ecosystem apparent quantum yield $(\alpha)$ and maximum photosynthesis rate $\left(P_{\max }\right)$ of different forest ecosystems in China. Agricultural and Forest Meteorology 137:176-187.

Zhaо, L., S. Gu, G. Yu, X. Zнао, Y. LI, S. Xu, And H. Zhou. 2006. Diurnal, seasonal and annual variation in net ecosystem $\mathrm{CO}_{2}$ exchange of an alpine shrubland on Qinghai-Tibetan plateau. Global Change Biology 12:1940-1953.

\section{APPENDIX: LIST OF SYMBOLS}

\section{Latin Symbols}

$A_{\max }=$ maximum gross photosynthetic assimilation $(\mathrm{mg}$ $\mathrm{CO}_{2} \cdot \mathrm{m}^{-2} \cdot \mathrm{s}^{-1}$ )

$F_{\mathrm{c}}=$ net $\mathrm{CO}_{2}$ flux $\left(\mathrm{mg} \mathrm{CO} \mathrm{CO}_{2} \cdot \mathrm{m}^{-2} \cdot \mathrm{s}^{-1} ; \mathrm{g} \mathrm{CO}_{2} \cdot \mathrm{m}^{-2} \cdot \mathrm{d}^{-1}\right)$ $\mathrm{GPP}=$ annual gross primary production $\left(\mathrm{g} \mathrm{CO}_{2} \cdot \mathrm{m}^{-2} \cdot \mathrm{yr}^{-1}\right)$ IntNEE $=$ integrated net ecosystem $\mathrm{CO}_{2}$ exchange $(\mathrm{g}$ $\mathrm{CO}_{2} \cdot \mathrm{m}^{-2}$ )

$k_{\mathrm{T}}=$ coefficient in the exponential equation for respiration temperature dependence $\left({ }^{\circ} \mathrm{C}\right)^{-1}$

$L=$ leaf area index $\left(\mathrm{m}^{2} \cdot \mathrm{m}^{-2}\right)$

$L_{\max }=$ seasonal maximum leaf area index $\left(\mathrm{m}^{2} \cdot \mathrm{m}^{-2}\right)$

$P_{\mathrm{d}}=$ daytime integral of the net ecosystem $\mathrm{CO}_{2}$ flux (g $\mathrm{CO}_{2} \cdot \mathrm{m}^{-2} \cdot \mathrm{d}^{-1}$ )

$P_{\mathrm{g}}=$ gross photosynthetic assimilation $\left(\mathrm{mg} \mathrm{CO} \mathrm{CO}_{2} \cdot \mathrm{m}^{-2} \cdot \mathrm{s}^{-1} ; \mathrm{g}\right.$ $\mathrm{CO}_{2} \cdot \mathrm{m}^{-2} \cdot \mathrm{d}^{-1}$ )

$Q=$ incoming photosynthetically active radiation $(\mu \mathrm{mol}$ quanta $\cdot \mathrm{m}^{-2} \cdot \mathrm{s}^{-1} ;$ mol quanta $\cdot \mathrm{m}^{-2} \cdot \mathrm{d}^{-1}$ )

$Q_{\mathrm{a}}=$ absorbed photosynthetically active radiation ( $\mu \mathrm{mol}$ quanta $\cdot \mathrm{m}^{-2} \cdot \mathrm{s}^{-1} ;$ mol quanta $\left.\cdot \mathrm{m}^{-2} \cdot \mathrm{d}^{-1}\right)$

PCPN $=$ atmospheric precipitation $\left(\mathrm{mm} \cdot \mathrm{d}^{-1}, \mathrm{~mm} \cdot \mathrm{yr}^{-1}\right)$

$r_{\mathrm{d}}=$ daytime ecosystem respiration rate $\left(\mathrm{mg} \mathrm{CO} \mathrm{CO}_{2} \cdot \mathrm{m}^{-2} \cdot \mathrm{s}^{-1}\right)$

$R_{\mathrm{d}}=$ daytime ecosystem respiration $\left(\mathrm{mg} \mathrm{CO} \mathrm{CO}_{2} \cdot \mathrm{m}^{-2} \cdot \mathrm{s}^{-1} ; \mathrm{g}\right.$ $\mathrm{CO}_{2} \cdot \mathrm{m}^{-2} \cdot \mathrm{d}^{-1}$ )

$R_{\mathrm{e}}=$ total ecosystem respiration $\left(\mathrm{mg} \quad \mathrm{CO}_{2} \cdot \mathrm{m}^{-2} \mathrm{~s}^{-1} ; \mathrm{g}\right.$ $\mathrm{CO}_{2} \cdot \mathrm{m}^{-2} \cdot \mathrm{d}^{-1}$ )

$\mathrm{RE}=$ annual total ecosystem respiration $\left(\mathrm{g} \mathrm{CO}_{2} \cdot \mathrm{m}^{-2} \cdot \mathrm{yr}^{-1}\right)$

$\mathrm{RH}=$ air relative humidity $(\%)$

$R_{\mathrm{n}}=$ nighttime ecosystem respiration $\left(\mathrm{mg} \mathrm{CO} \mathrm{CO}_{2} \cdot \mathrm{m}^{-2} \cdot \mathrm{s}^{-1} ; \mathrm{g}\right.$ $\mathrm{CO}_{2} \cdot \mathrm{m}^{-2} \cdot \mathrm{d}^{-1}$ )

$R_{\text {net }}=$ net radiation $\left(\mathrm{W} \cdot \mathrm{m}^{-2} ; \mathrm{MJ} \cdot \mathrm{m}^{-2} \cdot \mathrm{d}^{-1}\right)$

$r_{0}=$ ecosystem respiration rate at temperature $T_{\mathrm{s}}=0^{\circ} \mathrm{C}(\mathrm{mg}$ $\mathrm{CO}_{2} \cdot \mathrm{m}^{-2} \cdot \mathrm{s}^{-1}$ ) 
$r_{\mathrm{n}}=$ nighttime ecosystem respiration rate $\left(\mathrm{mg} \mathrm{CO} 2 \cdot \mathrm{m}^{-2} \cdot \mathrm{s}^{-1}\right)$

$R_{\mathrm{n}}=$ nighttime ecosystem respiration $\left(\mathrm{mg} \mathrm{CO} 2 \cdot \mathrm{m}^{-2} \cdot \mathrm{s}^{-1} ; \mathrm{g}\right.$ $\mathrm{CO}_{2} \cdot \mathrm{m}^{-2} \cdot \mathrm{d}^{-1}$ )

$R_{\text {net }}=$ net radiation $\left(\mathrm{W} \cdot \mathrm{m}^{-2} ; \mathrm{MJ} \cdot \mathrm{m}^{-2} \cdot \mathrm{d}^{-1}\right)$

$T_{\mathrm{a}}=$ air temperature $\left({ }^{\circ} \mathrm{C}\right)$

$t_{\mathrm{r}}=$ time of sunrise $(\mathrm{h})$

$t_{\mathrm{s}}=$ time of sunset $(\mathrm{h})$

$T_{\mathrm{s}}=$ soil temperature (typically, at 5 -cm depth; ${ }^{\circ} \mathrm{C}$ )

$T_{\text {year }}=$ mean annual temperature $\left({ }^{\circ} \mathrm{C}\right)$

$V_{\mathrm{c} \text { max }}=$ maximum rate of carboxylation $\left(\mathrm{mg} \mathrm{CO} \mathrm{CO}^{-2} \cdot \mathrm{s}^{-1}\right)$

$\mathrm{VPD}=$ vapor pressure deficit $(\mathrm{kPa})$

$W_{\mathrm{s}}=$ volumetric soil moisture $\left(\mathrm{m}^{3} \cdot \mathrm{m}^{-3}\right)$

\section{Greek Symbols}

$\alpha=$ apparent quantum yield of gross photosynthetic assimilation $\left(\mathrm{mmol} \mathrm{CO}_{2} \cdot \mathrm{mol} \mathrm{quanta}^{-1}\right)$

$\varepsilon, \varepsilon_{\text {ecol }}=$ gross ecological light-use efficiency $\left(\mathrm{mmol} \mathrm{CO}_{2} \cdot[\mathrm{mol}\right.$ incident quanta $]^{-1}$ )

$\varepsilon_{\text {phys }}=$ gross physiological light-use efficiency $\left(\mathrm{mmol} \mathrm{CO}_{2}\right.$. $[\text { mol absorbed quanta }]^{-1}$ )

$\lambda=$ latent heat of evaporation $\left(\mathrm{MJ} \cdot \mathrm{kg}^{-1}\right)$

$\theta=$ convexity (curvature) coefficient of the light-response equation (dimensionless)

$\rho_{\mathrm{d}}=$ diffusive resistance to $\mathrm{CO}_{2}$ transport $\left(\mathrm{s} \cdot \mathrm{m}^{-1}\right)$

$\rho_{\mathrm{x}}=$ carboxylation resistance to carbon transport $\left(\mathrm{s} \cdot \mathrm{m}^{-1}\right)$ 